\title{
The role of coloristic decoration of the architectural order in shaping the façade tectonics in the Baroque period
}

\author{
Bogna Ludwig ${ }^{1, *}$
}

1* Wrocław University of Science and Technology; bogna.ludwig@pwr.edu.pl

\begin{abstract}
The article is dedicated to the role of polychrome solutions of the architectonic order in the concept of the Baroque façade. The ancient principles of designing architectural structures, inherited from the Renaissance were subjected to reinterpretations in order to impart different expressive values. The arrangements of façades, initially balanced or even horizontal, were replaced by ambiguous bivalent compositions. Vertical layouts began to dominate in the Baroque. Appropriately selected polychrome of the elements of the order could emphasize the compositional expression. The relationship between the layout of the polychrome in a given architectural order and the expression of a work of art has been established for quite a long time. However, the generally available data on color schemes of architectural structures in baroque buildings are still not fully organized. The paper analyses examples of Baroque façades preserved in their original state and revalorized in recent years after thorough conservator's research in the field of architecture and color. The examples are mainly designed in the so-called great order, i.e. pertaining largely to church façades. In the Baroque, the vertical direction of the composition was strongly emphasized by multiplying or applying perspective arrangements of supports, and finally by embattled entablatures. The decisive field of change became the shaping of the coloristic decoration of the entablature - decisions regarding the material and color separation of elements of the frieze above the supports. The uniform color of all vertical elements of the façade structure guaranteed an unambiguous verticality of the composition.
\end{abstract}

Keywords: color; polychrome, baroque architecture; 16th-18th century; entablature; architectural order.

\section{Introduction}

Baroque architecture affects the viewer due to the expression of its composition shaped by means of carefully selected forms, profiles, connections and proportions of the elements of the order. The ancient principles of designing architectural structures, inherited from the Renaissance and already fully known and refined, were subjected to reinterpretations as early as the late Renaissance and Mannerism in order to impart different expressive values. The arrangements of façades, initially balanced or even horizontal, were replaced by ambiguous bivalent compositions. Vertical layouts began to dominate in the Baroque. From the conceptions of Borromini and Guarini, the primacy of the compositional expression over the maintenance of faithfulness to the rules of architectural order was marked. Thus the developing trend called the aclassical baroque exposed the importance of the dynamics of forms and vertical arrangements in the façade tectonics.

In the case of the first Italian Baroque realizations, whole façades, or at least architectural details were made of stone and preserved in its natural color, and only sometimes the background of the façade was painted. However, in the further evolution of the concept, especially in the projects of South German architects, appropriately selected polychrome of the elements of the order could emphasize the compositional expression of architectural 
structures. The decisive field of change became the shaping of the coloristic decoration of the entablature.

\section{Status of research. Materials and methods}

For years, the issues of the coloring of Baroque façades have been dealt with by conservators, who study the preserved polychromies and reproduce them in comprehensive façade restoration projects. This information is collected in the form of reports on the work carried out. Few of the research results are presented in the form of articles (e.g. Koller 1998 and 2010, Storemyr 2001, Brzezowski and Wanat 2002). There appear single studies summarizing achievements in selected thematic areas, e.g. concerning a certain group of architectural objects, or a geographical region or a single town (Knoepfli 1965, Philippot et al. 1986, Grognardi and Tagliasacchi 1988, Brzezowski 2000 and 2010, Dettloff 2010, Białobłocka 2014, Koller 2017). The issue is also discussed along with general problems of restoring original coloring of historical objects (Muratore 2010). The relationship between the layout of the polychrome in a given architectural order and the expression of a work of art has been established for quite a long time (Zander 1984). However, the generally available data on color schemes of architectural structures in baroque buildings are still not fully organized.

At the beginning of the considerations, the presentation of the basic principle of shaping the structures of modern architecture, i.e. application of the architectural order, will serve to indicate the role of individual elements in forming certain compositional effects on the façades. This presentation of selected examples of solutions applied to the polychrome of architectural details of the Renaissance times will create the background for the development of concepts of the subsequent period. The paper will analyze examples of Baroque façades preserved in their original state, reflected in iconography, and revalorized in recent years after thorough conservator's research in the field of architecture and color. The examples are mainly designed in the so-called great order, i.e. pertaining largely to church façades.

The role of polychrome solutions of individual elements of the order structure in the architectural concept of the Baroque façade will be defined. Describing particular color schemes will make it possible to point out the most important differences determining deeply the changes of architectural expression. The presented methods of selecting color schemes will reveal specific Baroque solutions used to emphasize the tectonics of the building and shape artistic effects with their help. The aim will be to identify the types of solutions and to present the most probable genesis of individual design concepts of color schemes for Baroque architectural structures. At the same time it will make it possible to trace the development and transformation of artistic concepts in this area.

\section{Historical and problematic background}

\subsection{Architectural orders in modern times - tradition and innovation}

After innovations in the development of architectural structures during the Gothic period, in the Renaissance the return to classical forms imposed a rigor on designers within which they sought new aesthetic solutions. The starting point for architects were decorative systems drawn from ancient Greek and Roman designs. The architectural order derived from antiquity, used again on the façades of buildings since modern times, has its genesis in the structure. It corresponds to the system of supports - columns and pillars, beams and arches supported by them, as well as mullions, lintels and window arches framing the entrance and window openings. As a result, it forms a system of façade vertical and horizontal divisions. Already in ancient times, in addition to its original structural use, the architectural order system was used as wall decoration. The compositions of the four basic orders, Doric (Tuscan), Ionic, Corinthian and Composite, following ancient examples, introduced a different kind of expression from the outset. Initially, the early Renaissance derived spontaneous, emotional inspiration from ancient concepts. A narrow range of possibilities for shaping the expressive charge through extremely subtle, intellectual movements in architecture, strictly observing the rules of order, was used by 
the masters of the mature Renaissance. Reinterpretations aiming at a sophisticated play of opposites were a design principle in Mannerism. Redefinition of classical arrangements and saturation of individual details with new solutions, changes in architectural profiles provided an opportunity to enrich the expression in the Baroque period. This method led to deformation and extreme plasticization of forms in late Baroque and Rococo.

Apart from the choice of the architectural order and the elaboration of the proportions of the elements, the selection of the profiles of the architectural details, in particular of the entablature, was of key importance. The development of the model of the crowning cornice, sometimes on a scale of 1:1 (e.g. Michelangelo's wooden model of the cornice of the Pallazzo Farnese in Rome from 1547, or the stone entablature of St. Peter's Basilica in Rome from 1560) (Conforti et al. 2020, Ferretti 2020, Bellini 2011), was one of the most important elements of the project. Reinterpretation of the canon of architectural orders served to shape the various expressive effects of the work. Starting with Michelangelo, designers began to study the modeling of architectural detail (linguaggio architectonico). The famous artist attempted to redefine the system of architectural decoration by using mannerist ways to unconventionally apply individual architectural details, contrary to the original assumptions, or to apply various deformations and rearrangements of the components, e.g. by inserting consoles or elongated triglyphs in place of chapiters, or by visually suspending heavy columns without a base (Portoghesi 1982, p. 131). Much more important for the development of methods of architectural design was the search, seemingly less spectacular, for enhancing the plasticity of the detail by deepening the chiaroscuro or reducing it through the use of strongly protruding, concave or convex, slightly flattened profiles in the entablature (Portoghesi 1982, pp. 141-148). Apart from classical motifs, it was Gothic and early Christian forms, which the artist studied on the basis of Roman buildings, that were his models. Theoretical considerations and realizations of his successors - designers of the Baroque period - also followed this direction. Each of them developed a characteristic set of forms. Pietro da Cortona, in contrast to strong carving used in the façade, which provided deep chiaroscuro, preserved small, balanced profiles within the details with subtle shadows, which ensured full visibility and clarity of the shapes. Gian Lorenzo Bernini designed very classical sections of cornices, architraves and pedestals with sharp, expressive contour. Extremely interesting ideas were implemented by Francesco Borromini. He returned to his search based on the development of new architectural profiles, analyzing classical and Gothic forms and drawing inspiration from nature. Thanks to that his architectural decorations were varied, showing an intensity of shadow and sharpness of lines. German designers of the mature Baroque had similar interests. Balthasar Neumann designed architectural details in his buildings in a scholarly way using sophisticated modular constructions. In Bohemia (Czechia), the most innovative approach to shaping architectural profiles, which provided an opportunity to gain new means of expression, was represented by Christoph and Kilian Ignaz Dienzenhofer. They also used untypical, concave, elongated sections, referring to Gothic solutions. Thanks to that, the façades of the buildings erected by them were enriched with various chiaroscuro with deepened shadows, and the edges of the details, except for special cases, were described with a soft blurred contour (Wrabec 1991, Pavlík 2011,).

The appropriate selection of elements, their size, plasticity, profiling and interrelation of individual elements, as well as the saturation with decoration and arrangement on the façade determined the expressive character of the architectural composition. Small architectural details, slightly protruding from the wall, create a delicate, linear decoration. In this way, the wall receives the form of a sheet enclosing the space in a strictly defined place, both in the direct view and from a perspective. Massive, prominent forms, with a strong chiaroscuro dynamize the architecture, introduce the impression of movement of space, may blur the spatial boundaries. Entablatures, cornices, parapets emphasize horizontal features, make the objects seem lower and optically heavier, bind them to the ground and close the space. The balance of both divisions creates on the fa- 
çades a kind of network that stabilizes the composition. Particular articulation of such elements as columns, pilasters, lisens, risalitic walls and the embattled entablature above the supports gives the buildings a vertical character. This determines their apparent height or slenderness. It creates the illusion of lightness, sometimes even dematerialization.

\subsection{Colors of the elements of architectural order in the Renaissance - color and material}

At the beginning of the Renaissance both in architectural practice and in the first treatises no rules concerning colors in architecture were revealed. The resulting recommendations were limited at most to advice concerning the choice of materials; types of stone. Leon Battista Alberti partly connected properties of stones with their colors (Alberti 1541, L. I, cap. III, pp. 25-26, 1565, pp. 37-39). Sebastiano Serlio described materials used in ancient buildings (e.g. the porphyry frieze of the Pantheon) (Serlio 1540, p. XIIII). Only later did Palladio identify white as the most suitable color for temples (Palladio 1581).

In Florence, the durable, heavy pietra forte stone was used to finish the façades, despite the difficulty of its treatment; it gave them the desired effect of rusticity and defense (Palazzo Pitti, Palazzo Medici Riccardi, Palazzo Strozzi). Leon Battista Alberti kept this traditional material and uniform coloring, introducing decorations typical of the order (Palazzo Rucelai) (Turrini 2011). It was still used at the end of the 16th century (Buontalenti, façade of the church of Santa Trinita, 1593-1594). Alberti also took up the Roman method of applying cladding of precious stones, choosing a single-colored version for the architecture of church façades (Tempio Maltestiano, after 1450, two types of marble were used: pietra d'Istria and pietra di Noriglio). He planned to achieve the same effect by replacing expensive materials with single-colored plaster (S. Andrea, Mantua, after 1472-1494) (Romoli 2004/2005). An important achievement in introducing this order was a return to the travertine cladding known in ancient Rome (Santa Maria del Popolo, 1472-1477 ca) (Waters 2016). In particular, the return to closer imitation of ancient monuments resulted in a preference for monochromatic or subdued colors. Bramante (1444-1514) consistently chose travertine cladding for his works. His followers did the same.

Precious stones, mainly marbles, were also used for interior architectural elements and monuments, especially architectural tombstones and altars, most often shaped in the form of triumphal arches. Most of these were also monochromatic: white or cream, e.g. tombstone of Bartolomeo Roverella in the church of S. Clemente in Rome, Andrea Bregno, 1476; Piccolomini altarpiece in the Cathedral in Siena, Andrea Bregno, 1480-1503; Tabernacolo in the Chapel del Miracolo del Sacramento in the church of Sant'Ambrogio in Florence, Mino da Fiesole, 1481; Altare del Sacramento in the Cappella Corbinelli, S. Spirito in Florence, Andrea Sansovino, c. 1490; monument to Cardinal Mendoza in the Cappella Maggior of the Toledo Cathedral, Andrea Sansovino, 1495; tombstone of Ascanio Sforza in the church of S. Maria del Poppolo in Rome, 1505, Andrea Sansovino; tombstone of Girolamo della Rovere in the same church, 1507, Andrea Sansovino; tombstone of doge Nicola Marcello, Pietro Lombardo, Tulio Lombardo; tomb monument of Giovani Moceni, 1500-1522, in the church of S. Giovani e Paolo, Venice; tombstone of Leo X, 1536-1542 (Hills 1999), Cordini Antonio detto Antonio da Sangallo il Giovane, Roma, S. Maria sopra Minerva. The most valued marbles from antiquity came from Carrara. They were personally selected by the main designers and contractors on site, in the quarry, for example, for the chapel of Loreto by Andrea Sansovino.

However, from the very beginning of the introduction of order structures in architecture, alternative coloristic solutions appeared. This was largely due to the materials used for the projects. In his works Filippo Brunelleschi used pietra serena, a stone that is resistant and quite easy to process from deposits near Florence (Fratini et al. 2014). Pietra serena was used to make monolithic elements - supports: columns and pillars, arches and profiled elements of the cornice and entablature, between which a smooth frieze was made and plastered in white. This resulted in a two-color horizontal composition (the 
interiors of the churches of San Lorenzo 1419, 1425-1445 and Santo Spirito 1434-1466, the façade of L'Ospedalle degli Innocenti 1419-1445, the Pazzi chapel 1430-1444), which became almost a design rule. Michelangelo developed this initially two-tone color principle (Medici Chapel 1520-1535). He then enriched his designs with tonal chiaroscuro effects (Laurenziana Vestibule, 1524-1534, 1571). Also in Roman architecture of the Renaissance period, two-colored solutions were used, thanks to the use of different backgrounds, usually light to brown plaster, it was possible to better expose the stone architectural details (Zander 1986, p. 28). In this way Michelangelo's Roman architectural projects were continued - the palaces on the Capitoline Hill by his students, among others Giacomo Della Porta, who used ochre plaster as a background for travertine, cream architectural order (Campisi 1986, Frommel 1995).

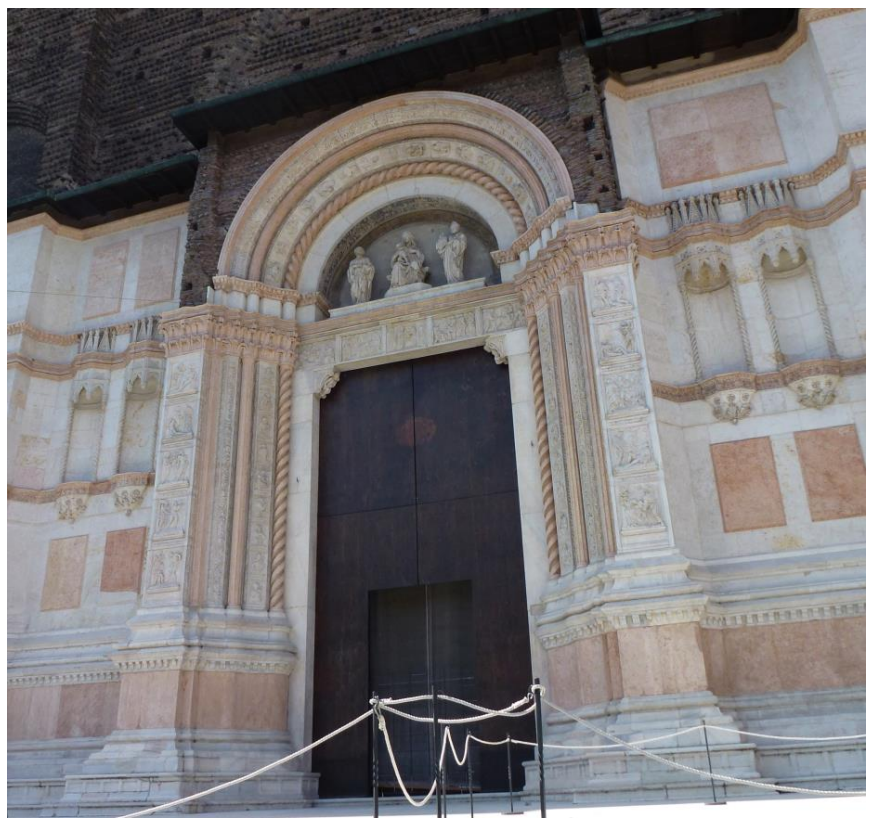

(a)

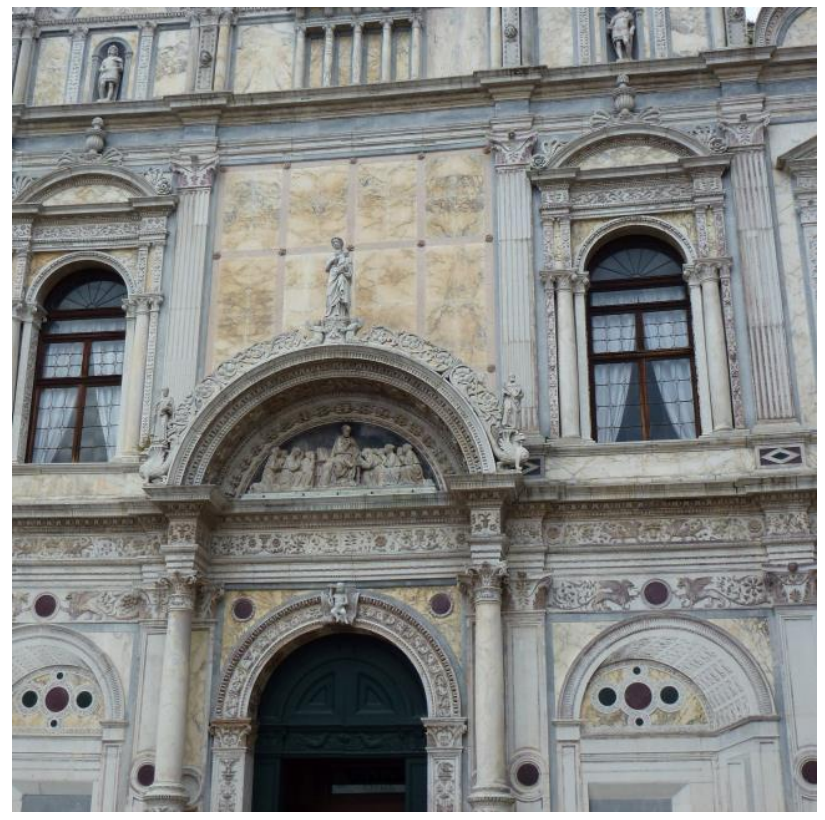

(b)

Figure 1. Renaissance colored architectonic orders: (a) traditional two-color combinations of façade marbles, Porta Magna of Basilica of San Petronio in Bologna made by Jacopo della Quercia of Candoglia marble (1425-1434); (b) colored marbles on the façade of Scuola San Marco in Venice (1490-1495). Photos Bogna Ludwig.

This principle of distinguishing a single-color architectural structure against a wall of a strongly contrasting color was used throughout the Renaissance and continued well into the Baroque. Various local types of stone were used and polychromies imitating the color of precious materials were made in places where no satisfactory color material was found. Apart from exposing grey architectural details on white and cream backgrounds, the opposite solution was used - bright structures were exposed on darker; grey or ochre ground. In the area of Milan, red elements were often introduced, made of the local pietra d'Angera limestone, used in Milanese buildings since the late Middle Ages (Fant et al. 2019) or painted in this very color (e.g. architectural orders on the façades of the Milanese palaces of Landrini and Bigli, 15th/16th c.). In such several basic versions Italian artists spread bichromatic solutions of Renaissance façades all over Europe (Koller 2003a).

At the same time, the medieval tradition of using color, which is particularly evident in the colorful paintings of the Trecento and Quatrocento, was continuously developed. More expensive and more varied materials were used especially since the beginning of the Renaissance in interiors. The northern Italian regions, especially Venice, showed a particular affinity to solutions using a wide color palette. However, also in Tuscany the order architecture was enriched by using the effect of small color additions, especially the most precious gilded and blue ones. In Rome the most significant pattern was the color solutions preserved in the interior of the Pantheon, where apart from the shafts of the columns and cladding of the walls made of one of the most expensive marbles (marmor 
numidicum, giallo antico) (Turrini 2007, Santoro 2021), dark red porphyry frieze was introduced in the main entablature (Serlio 1540, p. XIIII). Lucca Della Robbia (1399-1481), who collaborated with Brunelleschi and used the glazing technique he had invented, began to introduce colored, blue backgrounds; with time also friezes and realistically colored ornamental decorations were blue (Tabernacolo del Sacramento for the San Luca chapel, 1441-1442 ; altar chapels in the church of Santa Maria all'Impruneta together with Michelozzo). In the interior of the Pazzi chapel, where Della Robbia made tondos with representations of the Evangelists, the frieze was decorated in a similar way, with a blue background. Such color solutions were continued by his successors, especially Andrea della Robbia (1435-1525), who created tabernacles, altars and epitaphs (Madonna col Bambino tra angeli e santi, 1480, Convent of Santa Croce in Florence - Ala del Noviziato, Andrea e Giovanni della Robbia; Tabernacolo del Sacramento, 1512, Florence, Santi Apostoli; Adoration of the Magi, ca 1500-1510, Victoria and Albert Museum). Michelozzo also incorporated colored frieze backgrounds in a different material, using marble marquetry (Ciborio, Basilica di San Miniato al Monte, Firenze, 1448).

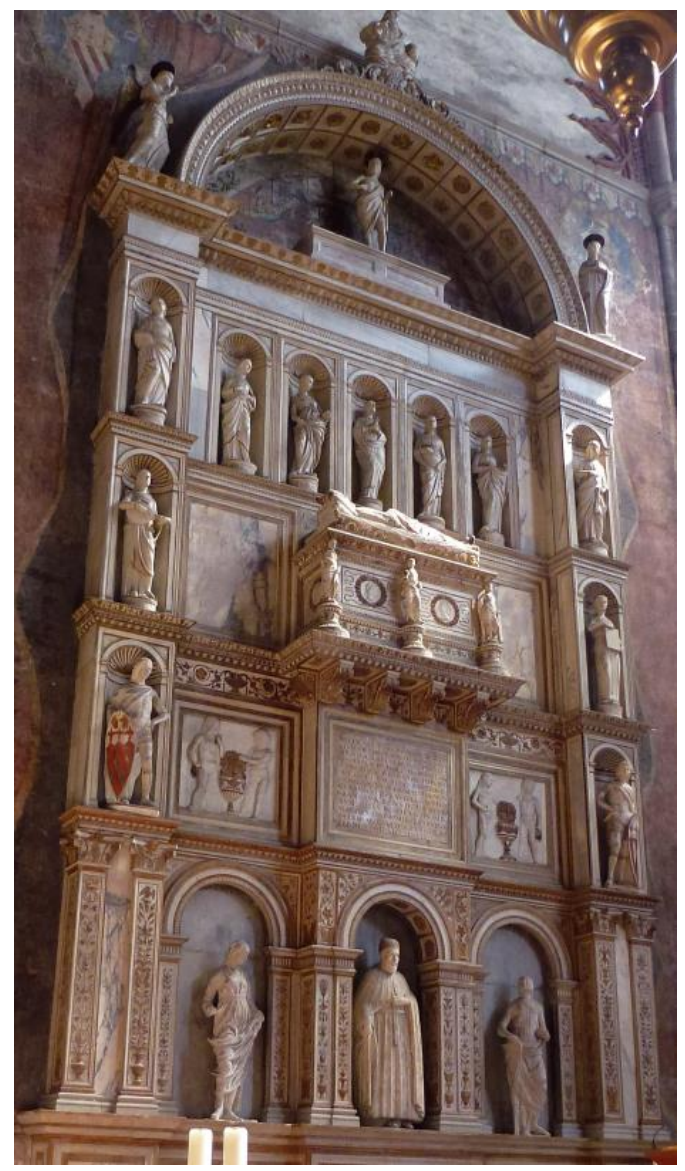

Figure 2. Colorful entablature and pilasters in sepulchral architecture. The funeral monument of Niccolo Trono in venetian church S. Maria Gloriosa dei Frari made by Antonio Rizzo (1476). Photo Bogna Ludwig.

Colorful backgrounds and colorful friezes of expensive marbles, green-grey or red-brown, were also used in tomb and altar architecture, both in Florence (tomb of Leonardo Bruni in the church of Santa Croce in Florence, Bernardo Rossellino, from 1445-1447, tombstone of Carlo Marsuppini in Santa Croce, Desiderio da Settiniano, 1459; tombstone of Ugo di Toscana, Mino da Fiesole, 1466-1481) as well as in Venice (tombstone of doge Andrea Vendramin in the church of Santi Giovanni e Paolo in Venice, Tullia and Antonio Lombard, 1493-1499, tombstone of Nicolo Orsini in the basilica of S. Giovanni e Paolo in Venice, completed 1514, main altarpiece in the church of San Rocco, 1517-1524, Venturino Fantoni). They were also used in monuments (the pedestal of the 
Gattamelata monument). This was also reflected in painted illusionist versions of architecture (Piero della Francesca, Madonna di Brera, 1472-1474, Giovanni Bellini, Pala di San Giobbe, c. 1487 and Pala S. Zaccaria, 1505).

Also in woodcarving works, where the whiteness of the stone was replaced by gilding, as was the case with the settings of Gothic polyptychs, the frieze was colored and often decorated, and painted dentils backgrounds were introduced (Tabernacolo dei Linaioli by Fra Angelico, 1433, Museo di San Marco in Florence with a cornice attributed to Lorenzo Ghiberti; Pala di San Zeno by Andrea Mantegna, 1457-1459, Basilica of San Zeno in Verona; Pala di Pesaro by Giovanni Bellini, c. 1474, c. 1472-1474). Such decoration of woodcarving works, consistent throughout Europe with medieval traditions, was adopted permanently throughout the modern period. This is how, for example, altars, epitaphs and pulpits typical of Lutheran churches were finished at the end of the 16th century and in the first half of the 17th century in Saxony, Silesia and Pomerania.

The varied colors of the frieze were used in polychromic interiors (Alberti and his continuators, S. Andrea in Mantua, after 1460; Domenico Ghirlandaio 1448-1494, Sala dei Gigli, 1482, Pallazo Vechio, Florence; Bramante, choir of the church of S. Maria presso San Satiro, 1482-1486, the Chigi Chapel in the church of S. Maria del Popolo in Rome, designed by Raphael, completed by Bernini) ((Murray 1971, Fano 1979, Camerota 2001). These manners of interior decoration with a colorful frieze of this architectural order were well immortalized by the paintings of the period (Masaccio's fresco "The Holy Trinity" of c. 1424, Sandro Botticelli, fresco in the Sistine Chapel illustrating the "Punishment of the Sons of Korah," 1481-1482, Carlo Crivelli, "Annunciation", 1486; interiors in Massolino's frescoes in the Brancacci Chapel, or Ghirlandaio in the Tornabuoni Chapel in the church of Santa Maria Novella in Florence).

Arrangements with a variety of colors appeared much less frequently on the external façades of buildings. In most cases, even when the walls had rich polychromies, the elements of architectural order remained monochromatic (e.g. the façade of the Oratorio di San Bernardino in Perugia, 1457-1461; the already mentioned façades of the Milanese palaces of Landrini and Bigli). However, the medieval methods of marquetry marble decoration were continued. Apart from Florence, façades finished with stone marquetry appeared in the Renaissance primarily in Venice and its provinces and Lombardy. However, different colors were still used primarily as a background for single-colored elements on façades (S. Maria del Fiore; Certosa di Pawia, 1473-1525). Sometimes areas of frieze made of colored marble were also introduced, as in interior architecture (in Venice: Scuola S. Marco; Scuola S. Rocco; Ca' Vendramin Calergi). Exceptional variations in color were made in small elements of the entablature, e.g. individual moldings (S. Maria Novella, Alberti, 1452-1456) (Desogus 2006). Colored column bases were also used. The multi-colored façade of the Coleoni Chapel in Bergamo (Giovanni Antonio Amadeo, 1470-1476) is a unique example. The architectural structure was in this case multicolored, made of a variety of stones - pink cornices and architraves of marble from Zandobbio, white and grey columns of marble from Candoglia and deep purple in the rosette elements of the pietra simona (Bugini and Folli 2005).

Colored marbles started to be fashionable especially since the pontificate of Pope Paul III - Alessandro Farnese (1534-1549). Marquetry was added to precious objects; walls and floors were decorated. Colorful column bases also appeared quite often. At first, especially in Roman architecture, granite shafts of columns and pilasters from spolia were used (in Palazzo Canceleria; in Bramante's works such as Tempietto and stairs in Cortile di Belvedere; loggias and porticoes in Palazzo Farnese; vestibule of Palazzo Farnese; courtyard of Palazzo Borghese) (Waters 2016). Then colored marbles were used or their imitations were painted in buildings that were decorated for the pope and his family, as in the halls and staircase of Palazzo Farnese in Caprarola or Villa Farnesina in Rome. In the last quarter of the 16th century the fashion from the papal court became widespread in the design of interiors, especially sacral interiors in all Italy. Expensive, multi-colored marbles coming not only from European quarries (marmor taenarium, rosso antico, portasanta from Chios) but also from Asia or Africa (marmor numidicum, gi- 
allo di Numidia, astracane from Tunisia), coming mainly from spolia (Catalogo 2005-2007), were used for interior decoration. Colored marbles were used for wall backgrounds and the faces of friezes in architectural orders (Licciardello 2008/2009). The method of marble marquetry, with the full range of possibilities used in utilitarian objects and furnishings, was introduced into the decoration of the Chapel of the Madonna di Trapani (1597-1599) (Vona 2020), in the Church of Del Gesù in Palermo, also known as Casa Professa, by Camillo Camilliani (mentioned between 1574-1603). In addition to illusory columns with twisted, richly decorated shafts, he also introduced a frieze with marquetry ornamentation.

Simultaneously with the return of the fashion for colored marbles, the use of colored stuccos and marbling began to spread. The techniques known in antiquity and sometimes still used in the Middle Ages began to be reintroduced. Initially certain types of stucco were used in quattrocento bas-relief, particularly models, but also realizations, even those decorating architecture (works by Donatello, Ghiberti, Jacopo della Quercia, Antonio Rossellino) (Bulfone Gransinigh and Amendolagine 2017). Deepening the knowledge of stucco and marbled works and their popularization, especially on the basis of discoveries of ancient works and information from the books of Pliny the Elder and Vitruvius (Book VII), made it possible to popularize the use of colorful solutions in interiors at much lower costs than stone marquetry. The dissemination of stucco, in particular by Raphael's associates Giovanni da Udine and Perino del Vaga, simultaneously influenced a much wider use of color in ornamental detail. Initially, however, all elements of architectural orders, except for the shafts of columns and pilasters, were made of white stone (Villa Madama, 1518-1523; Logge, 1518-1527). Later on, stone profiles started to be enriched with gilding. In the Vatican Stanzas (1508-1527), gilded astragals and cymatia (cymatium, ovolo) were applied, as well as the backgrounds of friezes and the shafts of pilasters decorated with ornaments (Kummer 2010). Giulio Romano in Loggia di Davide (1532-1534) in Palazzo del Te e.g. decorated elements of cymatium and astragal on the vault with gilding but kept the entablature in uniform color. Similar decorations were made by Giovani da Udine in interiors decorated in Venice (e.g. Palazzo Grimani). In Rome, Perino del Vaga used even more golden color, he introduced gilded backgrounds of friezes, consoles and dentils e.g. in the Regia di Vaticano Hall completed in 1573. Chapiters of pilasters were also often gilded e.g. in Galleria dei Carracci in Palazzo Farnese (1597-1600). In the entablature of Salone Sistino (The Sistine Hall) of the Vatican Library (1588), Domenico Fontana emphasized all the small details and ornaments with gilding.

In addition to polychrome and tinted plasters, striking imitations of expensive stone materials could be used in order architecture. The technique of marbling became particularly widespread in and around Venice, where Istrian limestone (pietra d'Istria), used for sculpture and stone cladding, also proved to be an excellent base material for marbling (Piana 2006). Marbling and hard stucco commonly used in the Venetian quattrocento (Bulfone Gransinigh and Amendolagine 2017) gained popularity and fame through its use in the works of famous artists such as Jacopo Sansovino, Andrea Palladio, and Vincenzo Scamozzi (Paternò 2016). They appeared in the halls and vestibules of the Doge's Palace, the Nuova Procuratia, the Foscari villa called Malcontenta, the Maser and Rotonda villas, in the Loggecta of San Marco in Venice or in the Palazzo dei Diamanti in Ferrara, as well as in the decoration of sacral interiors in Venice, with the most famous Palladian churches of San Giorgio Maggiore and Il Redentore at the forefront (Piana 2006). When designing architectural orders these artists usually remained with a two-color early-Renaissance solution (e.g. Palladio, Il Redentore, Sansovino Loggetta San Marco) or a monochromatic one (Palladio, San Giorgio).

In Sicily, where interior decoration received an unusually rich coloring, in addition to the shafts of the pilasters, colorful decorations were also introduced within the entablature. In the cornices and architraves the moldings were decorated in color or gilded, colorful backgrounds of cymatia and astragals as well as dentil bands and consoles were used, and the friezes and shafts of the supports were covered with colorful marbling, 
sometimes ornamented with marquetry or convex stucco. Antonio Ferraro and his sons applied decoration in convex stucco to the dark background of the frieze in the architectural order framing the walls of the choir of the church of San Domenico in Castelvetrano (1574-1580). Marble marquetry, marbling and stucco used together or even in a combined technique made it possible to create from the 1540 s to the 1560 s one of the richest decorative programs of sacral interiors in the Del Gesù Church. Similar programs were created later in other churches of Palermo and Trapani (Antista 2009).

Over time, marbling and its variant called scagliola became famous in northern Lombardy, particularly in the Valle Intelvi (Val d'Intelvi) in the Como region (Martinelli Braglia 1995, Mander 2005). Marbling techniques using colored materials were mainly applied to make furnishings, altars and tabernacles for churches. The effect of smoothed marble was particularly valuable. However, it was more difficult to ensure an expected color (Kurzej 2018, pp. 29-33, Wedekind 2010). Already at the turn of the 17th century intensely colored stuccos were used in this area in the entablature decorating the interiors of local churches (e.g. Oratorio-santuario di S. Pancrazio or S. Benedetto in Ramponio Verna, Como). Also in Bergamo, from about the middle of the 17th century, Giovanni Angelo Sala with his son Gerolamo made interior decorations by introducing to cornices and architraves painted backgrounds for gilded elements of palmettes, cymatia and astragals (S. Maria Maggiore) (Spiriti 2009). These regions and the neighboring ones, e.g. Ticino, abounded in stucco artists, but also stonemasons, builders and architects who erected representative buildings throughout Central Europe and further to Lithuania and Russia in the 16th and 17th centuries, up to the early 18th century. The earliest examples of Renaissance interior decoration north of the Alps are associated with the work of Italian stucco makers. White stucco prevailed (palace of Hvezda, near Prague, a Munich residence, Neugebaude palace, a chateau in Buczowice in the years 50s-80s of the 16th century) (Rinn 2010, Schmid 2010). However, we can also find the use of gilding and colored background, usually black or blue, for the elements of entablature, cymatia, astragals or ornaments on the friezes, in the rooms of the Town Hall in Landshut, e.g. in the hall of Italian Building (1536) or in the interior of the Boim Chapel in Lvov (1609-1615). The stuccos were only exceptionally painted to look like precious stones (Koller 1979, Kurzej 2018, pp. 32-33).

After the Thirty Years' War there were even fewer such examples of continuation of Mannerist solutions. We can point to the decoration of the choir vault of St. Peter's Cathedral in Trier, where dark blue backgrounds were used for ornaments of architectural details in entablature and friezes, or the interior of the church in Broumov (1687-1694, stuccowork by Tomasso and Antonio Soldati) (Stevens 2017), or slightly more frequently used in ornamental friezes backgrounds, e.g. pink (in the main nave of the monastery church in Garsten, 1682-1683). However, the predominant stucco decoration is entirely white (some of the most famous can be cited: Salzburg Cathedral, 1628, Passau Cathedral, 1668, the Theatine Church, now the Hofkirche in Vienna, 1673-1674, the Jesuit Church in Passau, 1675-1677, the Theatine Church in Munich realized until the 1780s, The Cistercian church in Schlierbach, 1682, the Viennese Schottenkirche Scots Church from the 1690s, the Cistercian church in Waldsassen, 1704 ) (Kurzej 2018, pp. 50-55).

However, gilding and colorful ornamentation of architectural elements and decorations appeared on façades only in exceptional circumstances. This was mainly the case with portals treated as a kind of separate work. Polychromic portals on tympana, but also within the richly carved entablature and pilaster chapiters appeared in the Como area, such as the works of Tommaso Rodari on the façades of the Cathedral of Como (Moizi 2020). Richly decorated portals became the most common architectural element of residential or urban buildings in Central Europe rebuilt or erected in this period by sculptors and stone masons from northern Italian regions. Most often made of sandstone, they were decorated with varied polychrome of colorful moldings, quarter rounds and other profiles, colorful backgrounds in cymatium and astragal stripes or consoles and dentils, as well as colorful fields of friezes. The richest used the most precious pigments: gold and blue. Earthy shades of yellow, red and black were commonly used. An example of such 
polychrome portals, mainly internal, are the works of Italian masters dating back to the beginning of the 16th century until the 30s. at the royal castle on Wawel Hill in Cracow (Grodzicka 1960, Stępien 1995). Recently, portals of tenement houses in Görlitz from the 20-80s of the 16th century or of the University in Helmstadt (1576-1597) have been reconstructed. In the same way the coloring of the entablature on the façades of the Schönhof in Görlitz (after 1526) (Bauer 2020) or the colorful background of the architectural ornaments on several other tenement houses in this town were reconstructed (until 2005) with multicolor details. Conservators established that elements of this type of polychrome may have been introduced even in Rome: in the entablature on the façade of Palazzo Pamphilij, probably designed by Carlo Rainaldi (until 1648), an astragal appeared on a grey-blue background (Leone 2016). Such solutions of Renaissance origin were still used in the second half of the 17th century, as it was established in the case of façades of monasteries in Henryków and Kamieniec Ząbkowicki in Silesia (Brzezowski and Wanat 2002), or the monastery in Lubiąż.

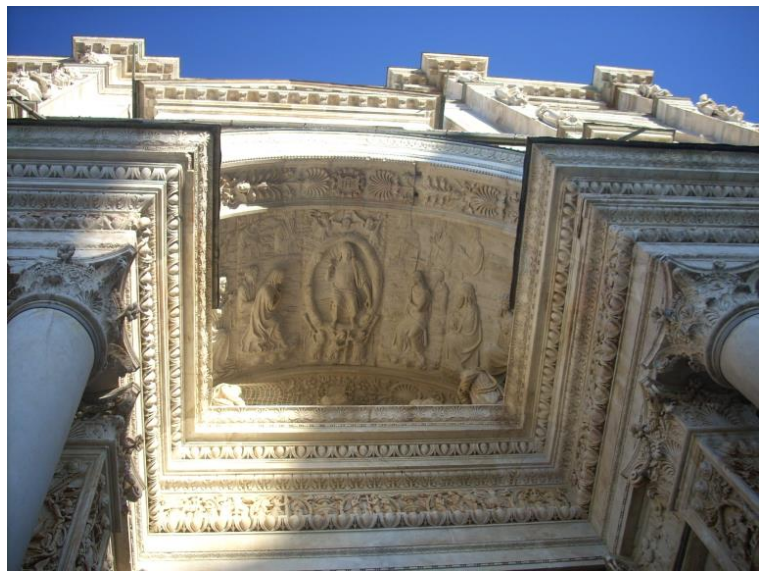

(a)

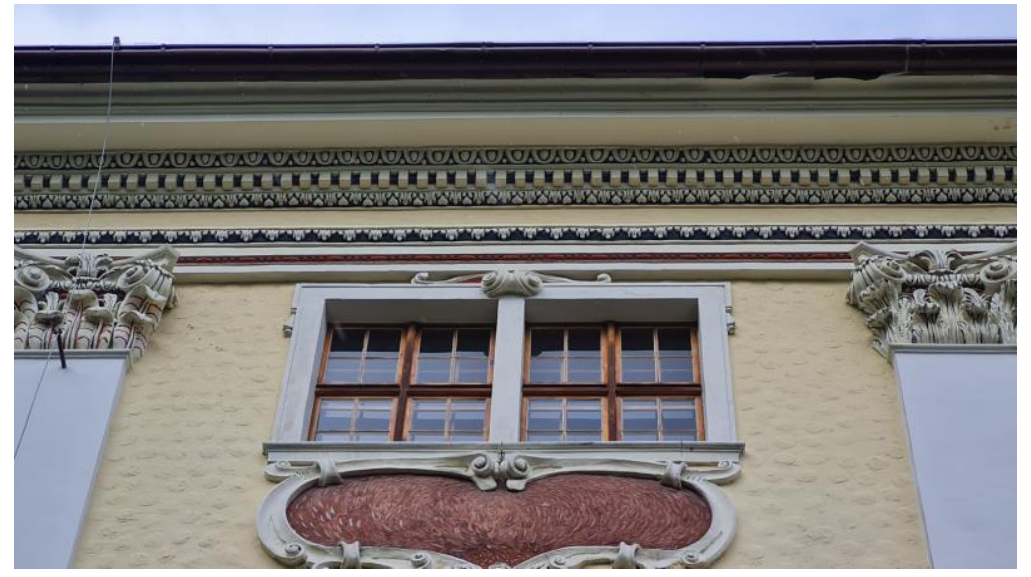

(b)

Figure 3. In the architectural orders of the Renaissance and Mannerism, color was used to bring out the details; to highlight the elements of the entablature, to mark the borders of cornices and architraves with moldings, to emphasize the decorative details or to strengthen the ornament on the frieze background: (a) A very plastic relief with a deep shadows gives expressiveness to the drawing of architectural ornaments. Portal entablature of the church of Santa Maria delle Grazie in Certosa di Pavia (1473-1525) made by Giovanni Antonio Amadeo and Benedetto Briosco (1501); (b) Color-varied polychrome of entablature. Colorful backgrounds in stripes of ovolo, astragal and dentils provide the legibility of a small ornamental detail. A fragment of the façade of the former Cistercian monastery in Kamieniec Ząbkowicki in Silesia (1675). Photos Marta Galantowicz and Katarzyna Ludwig.

In the architectural orders of the Renaissance and Mannerism, color was used to bring out the details; to highlight the elements of the entablature, to mark the borders of cornices and architraves with moldings, to emphasize the decorative details or to strengthen the ornament on the frieze background. The richest polychrome solutions used color to highlight all architectural elements of classical order systems: astragals, cymatia, dentils and consoles.

\section{Solutions of color schemes of façades in the Baroque period}

\subsection{Antique heritage and monochrome}

Ancient monuments, even if they once had the polychrome, have been preserved in the colors of natural stone until modern times; surface damage has often obscured the original color of the material. Such a form, strongly unified in terms of color, was accepted as the canon in force in antiquity. Only the chiaroscuro gave diversified tonal shades. This is how the objects were inventoried and in a similar form the project drawings were made (e.g. Giuliano da Sangallo, Michelangelo) (Elam 2017). Printing techniques imposed a graphic black and white form of presentation of architectural patterns first of all of orders in treatises from the earliest illustrated Renaissance (Serlio 1537, Pal- 
ladio 1581) illustrations to the works of Vitruvius and Alberti, up to works from the end of modern times. White elements or ornaments shown on a shaded background (Serlio), or then emphasized with chiaroscuro modeling of the form (Palladio, A. Pozzo), became a well-remembered figure of architectural norms.

Palladio, though emphasizing the special value of white in his treatise, contrary to the common belief, used quite a wide range of colors in his works (Paternò 2016). However, when using colorful backgrounds or column bases, e.g. quite intensive, made of facing brick, in the study of Loggia del Capitanio (combined with white stucco decoration and Istrian stone used in the ordering elements) or in the church of S. Giorgio in Venice (reddish columns of lesser order inside), he kept the entablature uniform, with facing of precious stone or plastered and with the polychrome in white or cream. In the case of the church of Il Redentore in Venice (1577-1586), white marble was used for the façade, while inside, for reasons of modesty dictated by the Capuchin rule, the order decorations, made of brick and plastered, pretended to be elements of white stone.

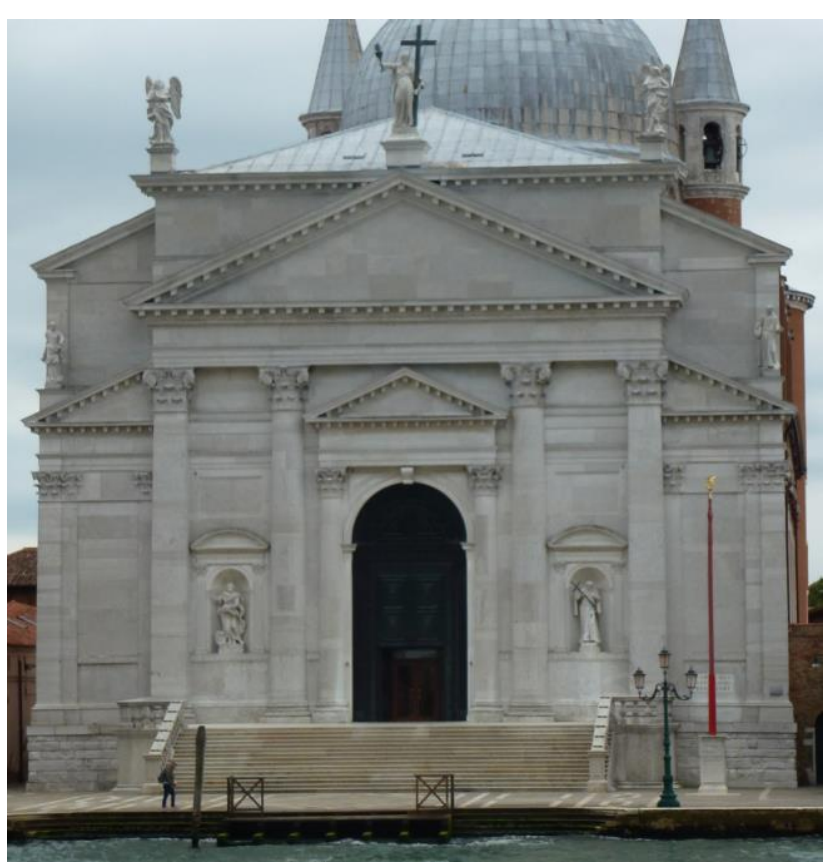

(a)

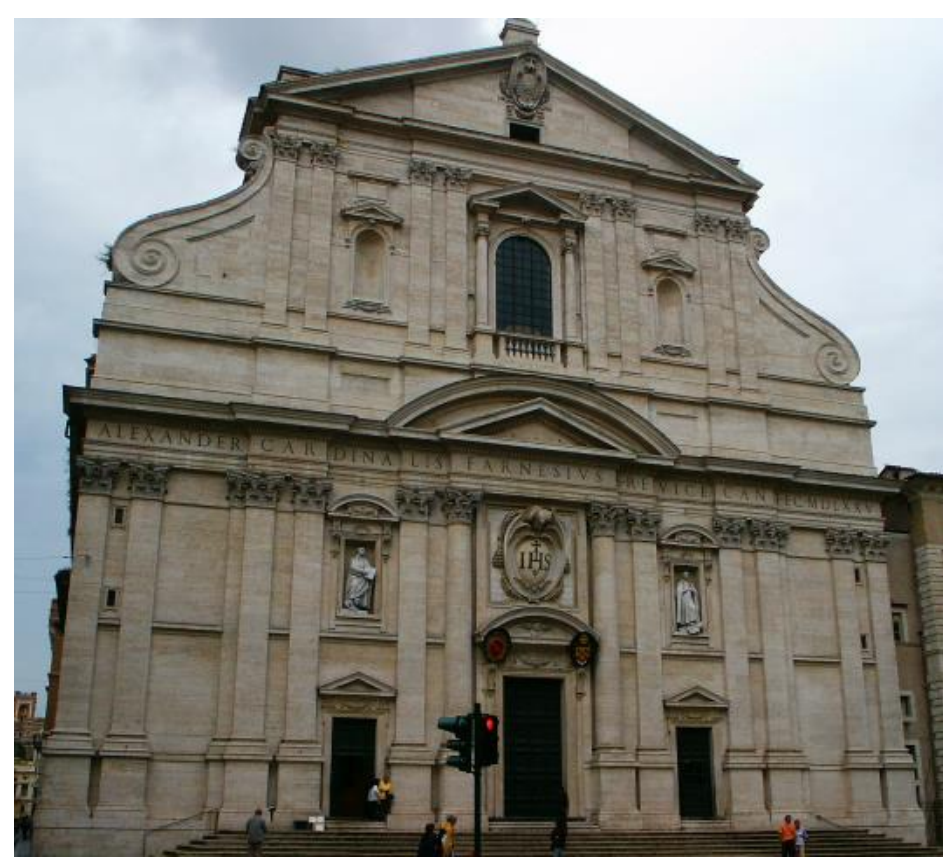

(b)

Figure 4. Monochrome facades: (a) made of pietra d'Istria - Il Redentore by Palladio in Venice; (b) and travertine - façade of the Jesuit church Il Gesù in Rome designed by Giacomo Della Porta (1584) particularly important for the development of sacred Baroque architecture. Photos Bogna Ludwig and Sebastian Wróblewski.

The architectural detail of monumental Baroque buildings in the early period was largely made of stone. In Rome in most cases a valuable material inherited from antiquity, travertine, was used (Bellini 2011). Carefully prepared material allowed to expose architectural forms, as in the case of churches from the turn of the century and styles. It can be seen in the realization of works starting from Mannerist works; particularly important for the development of sacral art, the façade of the Jesuit church Il Gesù (1584), designed by Giacomo Della Porta, the façade of the church of San Luigi dei Francesi (1589), designed by the same architect, façades by Martino Longhi the Elder - the church of Santa Maria della Consolazione (1587-1600), San Girolamo degli Schiavoni (1588-1590), façades of the church of S. Susanna (1597-1603) designed by Carlo Maderna, or the most important building of the Catholic Church - St. Peter's Basilica (1603-1607). Travertine became a distinctive feature of Roman buildings treated as an ideal material for shaping Baroque forms. Architects working in the Baroque period in Rome chose façades clad with this stone or, if funds were not sufficient, its imitation. In many cases the whole surface of the façade was covered with stone. Such were the façades of churches designed by Giovanni Battista Soria, a pupil of Maderna, such as the church of Santa Maria della 
Vittoria (1624-1626) (Acanto Restauri 2020a) and San Carlo ai Catinari (1635-1638), and the most famous architects of the period Pietro da Cortona - SS. Luca e Martina (1635-1664) or S. Maria della Pace (1656-1667), Francesco Borromini - San Carlo alle Quattro Fontane (1634-1667) and S. Agnese in Agone (1653-1657) and Gian Lorenzo Bernini - San Andrea al Quirinale (1658-1661), and later their collaborators and pupils e.g. Carlo Rainaldi - San Andrea della Valle (1655-1663) (Acanto Restauri 2020b) or Santa Maria in Portico in Campitelli (1659-1667).

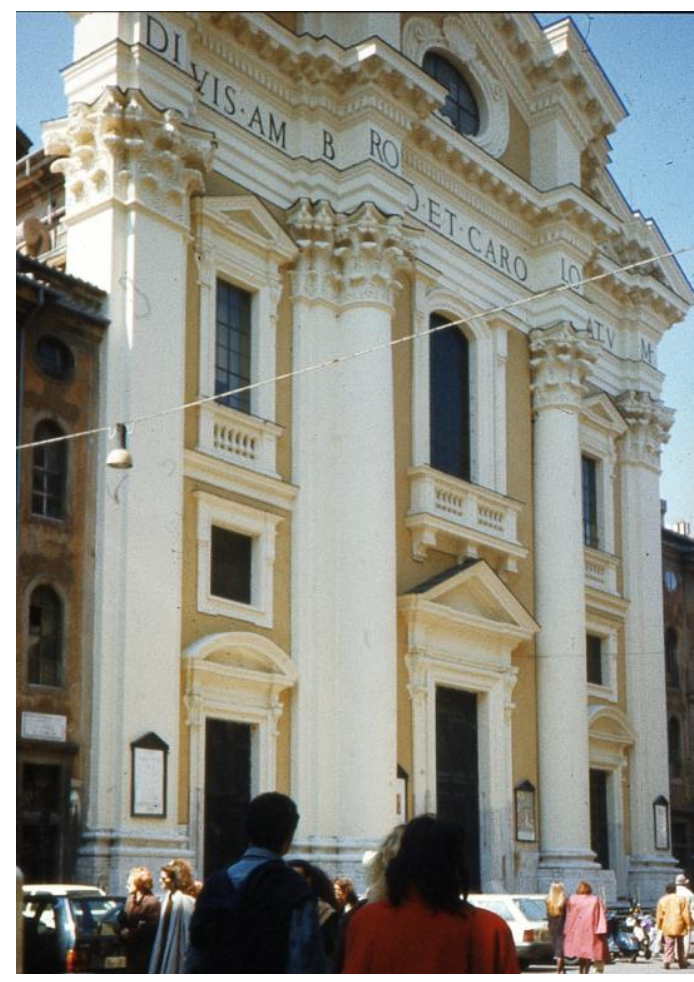

(a)

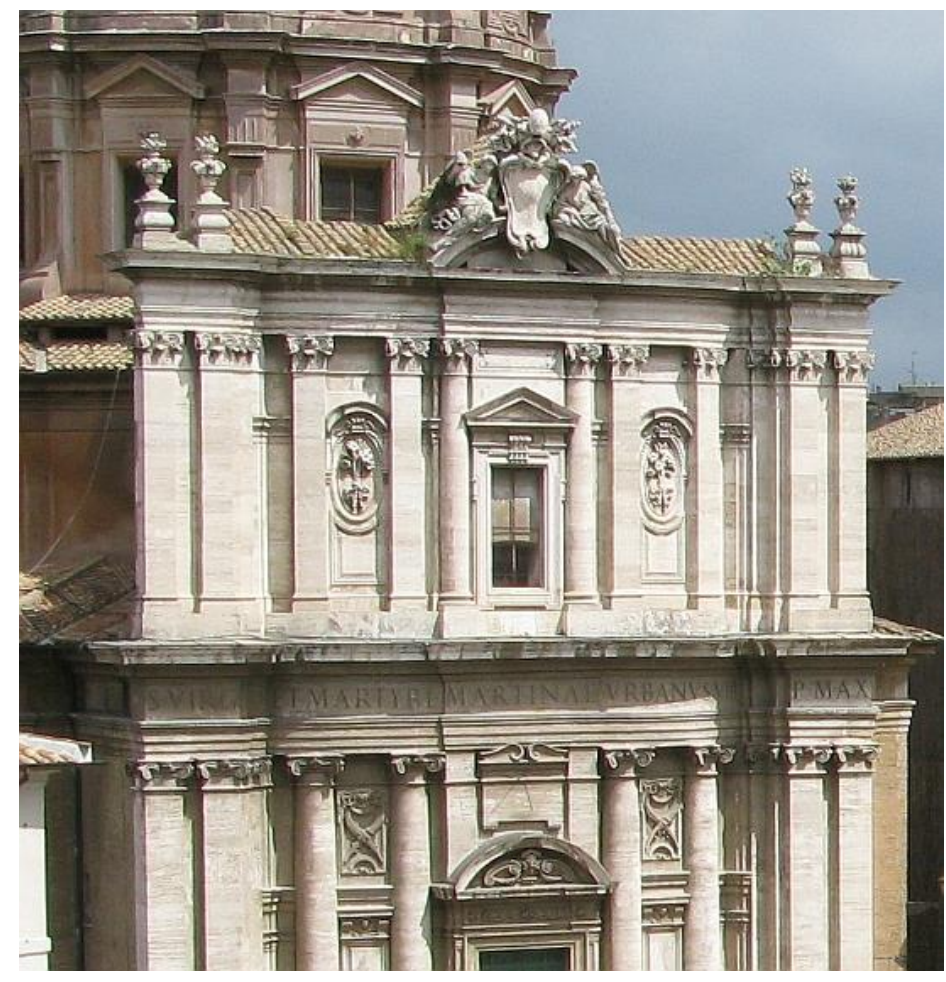

(b)

Figure 5. Monochrome architectural orders: (a) Stone entablature with an inscription frieze and a combination of a different background of the walls with a slightly contrasting architectural detail on the façade of the church of the Lombard community in Rome Santi Ambrogio e Carlo al Corso (1684), by Cardinal Luigi Alessandro Omodei, made under the direction of G.B. Menicucci; (b) Preserved small, balanced profiles within the details with subtle shadows, which ensured full visibility and clarity of the shapes. Cornices and architrave in the form of homogeneous stripes without ornamental detail. Fragment of the façade of the church of Santi Luca e Martina in Rome by Pietro da Cortona (1635-1664). Photos Bogna Ludwig.

Some of those artists consequently opted for monochromatic solutions also in interior design. Pietro da Cortona always designed decorations of sacral interiors in light stone (mainly travertine) and stucco, e.g. the interior of the church SS. Luca e Martina (Castelli Gattinara 2015). Borromini also preferred such a coloristic conception (Blunt 1979), which is best seen in the case of the interior of San Carlo alle Quattro Fontane, where the rich chiaroscuro offer a diverse range of shades made of light stucco architectural details. When cheaper or more convenient solutions were applied, with only constructional parts of order systems made of stone, most often a lighter shade of plaster, almost identical with the color of stone, was chosen for the background of walls and sometimes covering of friezes, e.g. in the work of F. Borromini S. Ivo della Sapienza (Acanto Restauri 2020c) or joint works of C. Rainaldi (1662-1677), C. Fontana and G.L. Bernini (1678-1681) like the twin churches in the Piazza del Popolo - Santa Maria dei Miracoli and Santa Maria in Montesanto (Benedetti 2012). In cases where the entire entablature was made of stone, especially when triglyphs and metopes friezes in the Doric order or inscription friezes were used, a two-colored rule of a different wall background with slightly contrasting detail was sometimes chosen, e.g. a light ochre color was used on the façade of the church of the Lombard community in Rome, Santi Ambrogio e Carlo 
al Corso (1684) by Cardinal Luigi Alessandro Omodei, made under the direction of G.B. Menicucci.

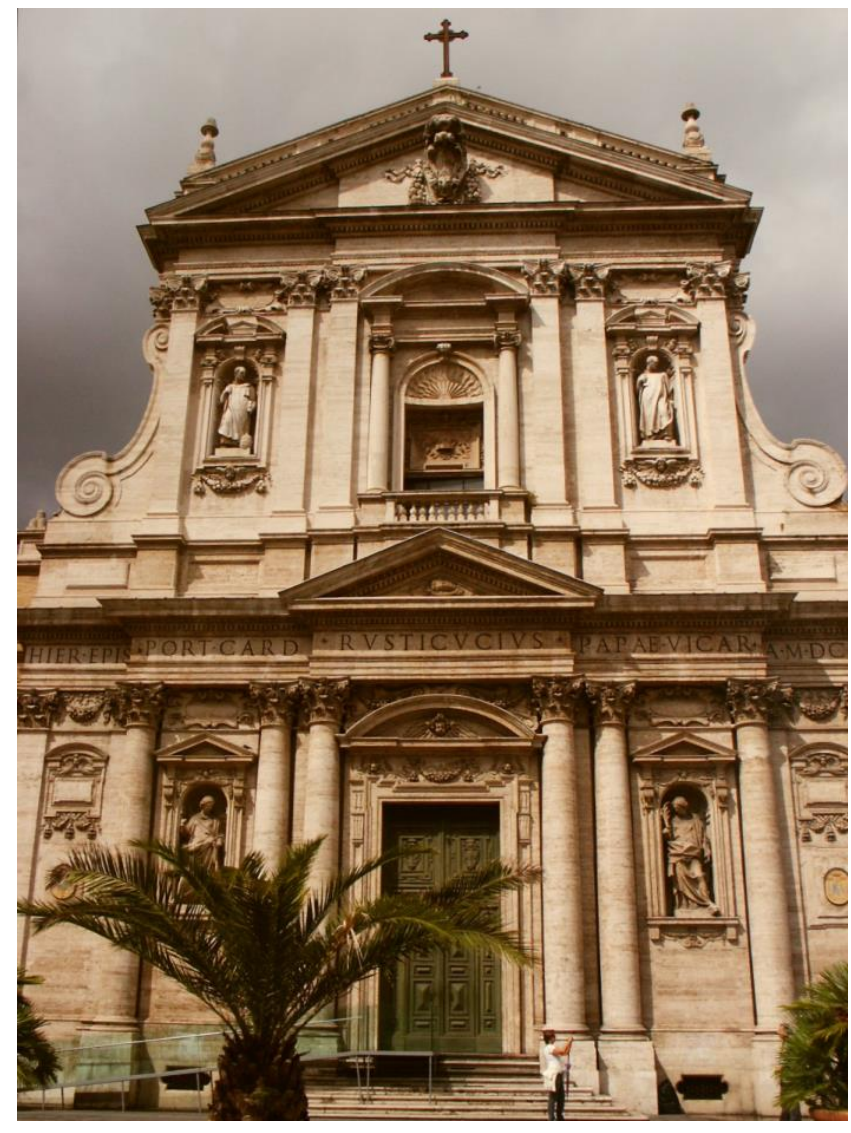

(a)

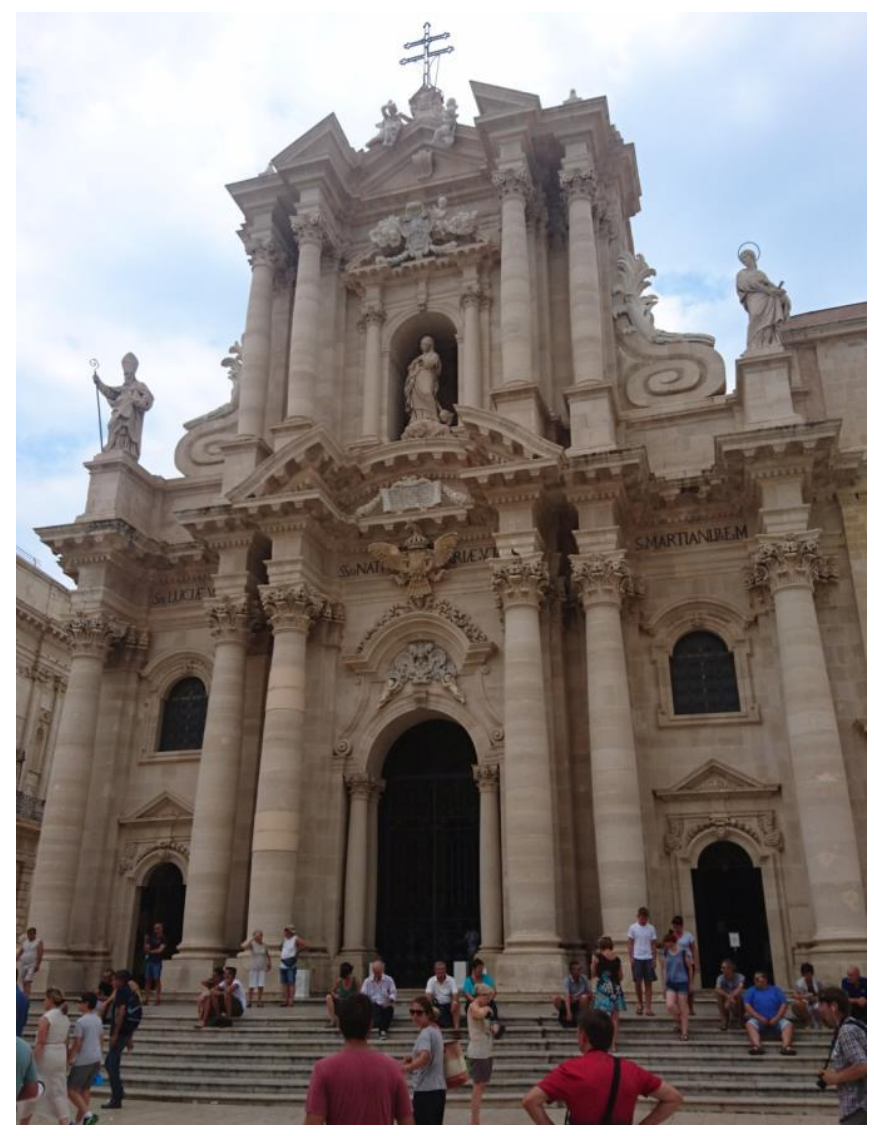

(b)

Figure 6. Monochromatic façades: (a) made of travertine - the façade of the church of S. Susanna in Rome designed by Carlo Maderna (1597-1603); (b) made of local limestone - the Cathedral of the Nativity of the Blessed Virgin Mary in Syracuse designed by Andrea Palma (1725-1753). Photos Sebastian Wróblewski.

The use of monochromatic solutions for the entire façade or the complete structure of the architectural order concentrated the design task on solving the light contrasts defining the limits of the forms, the ornamental drawing and the curvature of the profiles. Renaissance stone façades made it possible to precisely recreate ancient patterns. However, beginning with the works of Mannerists, it became more and more important to use chiaroscuro effects on profiled elements, operating with a stain, differentiating in perception the architectural forms. Gradual departure from linearism resulted in simultaneous simplification and dynamization of architectural forms, at the expense of removing small ornamental details: astragal and cymatium, and in time also dentil bands and consoles, as well as resignation from triglyphs and metopes and ornate frieze. According to the preserved antique models, the use of small details decorating the elements of architectural order such as palmettes, astragal and cymatium was recommended by Palladio in his treatise. He also used them in his own projects (Hemsoll 2016). The decoration of sima profiles with palmettes was abandoned as early as in the Renaissance. Michelangelo, in spite of willing modifications of classical patterns, preserved small decorations in the entablature of Sagrestia Nuova or in the cornice of Palazzo Farnese (1534-1548). Most Mannerist architects; Venetian, e.g., Jacopo Sansovio and Vincenzzo Scamozzi (Biblioteca Marciana 1537-1560, completed 1582-1586) or Roman, such as Domenico Fontana (Lateran palace, Quirinal palace, S. Trinita dei Monti), designed all the ornamentation in the entablature along with dentil bands and consoles. Some, such as Giacomo Della Porta, began to dispense with ornamental strips, usually retaining only the dentils and consoles under the cornices. Early Baroque artists also opted for simplified 
ornamental decoration of the entablature, e.g. C. Maderna (Vatican basilica, S. Sussana) and G.L. Bernini (S. Andrea al Quirnale) introduced only dentils and cymatia. Fr. Borromini usually limited himself to the preservation of consoles under the cornice, however in the cornice crowning the dome of S. Ivo della Sapienza, in a mannerist manner, he designed a cymatium, decorated with the heads of angels with wings instead of the egg-and-dart ornaments (DecArch 2014). Pietro da Cortona resigned from all such decorations. In his designs, cornices and architraves took the form of homogeneous strips, with the already mentioned subtle but clear chiaroscuro. This way was continued by the artists of mature and late Baroque, who differentiated and enriched chiaroscuro effects by means of extended, plastic profiles.

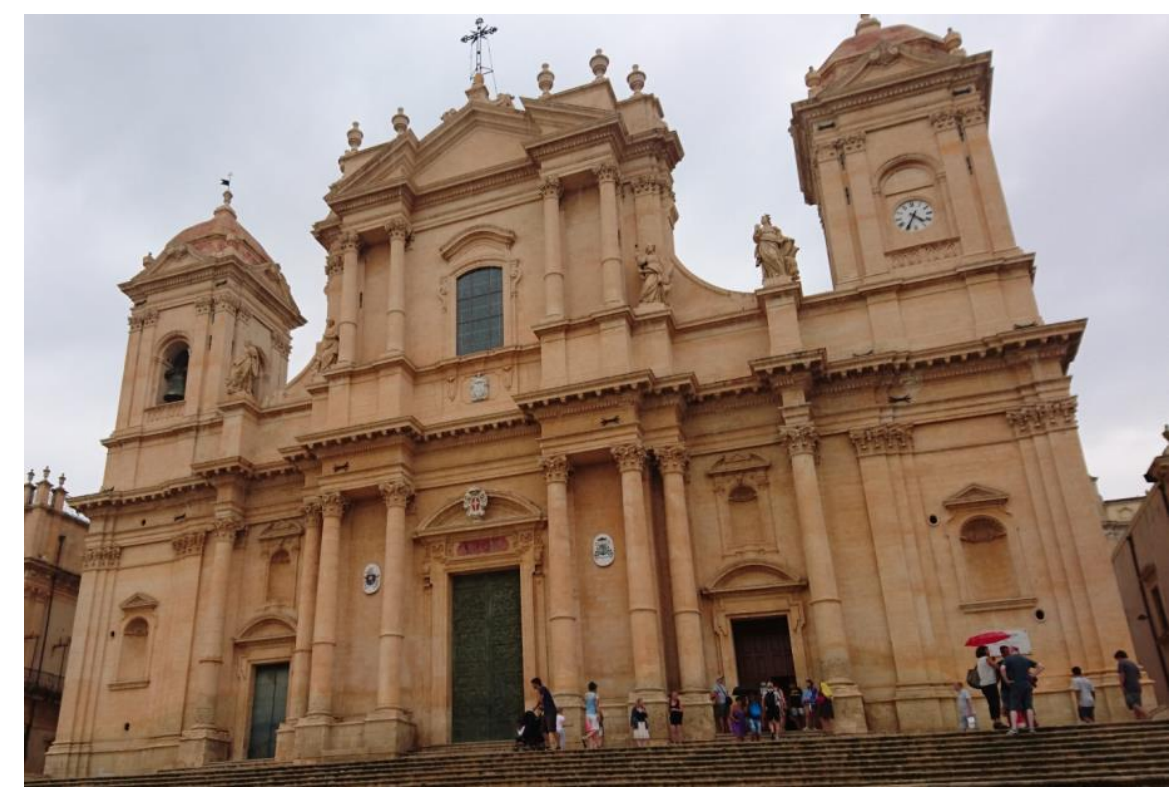

Figure 7. Monochromatic façade of the cathedral of Noto. Photo Sebastian Wróblewski.

The influence of Roman architecture was strong throughout Catholic Europe during this period. However, local building traditions were simultaneously continued, and natural material resources were utilized. Other types of stone were used, both for exposed elements of architectural orders and for wall cladding, especially in designs influenced by Roman Mannerist and early Baroque patterns as well as those of the late Baroque and mature Baroque inspired by the works of Borromini and Guarini. Marbles and limestones similar in color to travertine were chosen, e.g. in northern Italy pietra $d^{\prime}$ Istria was commonly used in the cities of the region and Venice itself, e.g. on the façades of the temples of S. Maria della Salute and S. Moisè, in southern Italy; in Lecce, pietra leccese, from which the façades of the churches of S. Croce, S. Angelo, S. Irene, Chiesa del Carmine and the cathedral were made; in Sicily, limestone from the area of Noto was used in the cathedral, the church of S. Salvatore and S. Francesco in this city, or limestone from the vicinity of Syracuse in the cathedral and church of S. Spirito.

Similarly, outside Italy, for example, in central France, local limestone sandstone (calcaire lutétien), already used in Romanesque and Gothic buildings, was still applied to façades of churches in St-Gervais-et-St-Protais, Saint-Paul-Saint-Louis, Val de Grace, Les Invalides or palaces in Versailles, Vaux-le-Vicomte, Compiègne, Chantilly, Écouen, Pierrefonds, Coucy; in Lower Austria, Eggenburg sandstone (Eggenburger Kalksandstein) was used, for example, on the facade of the Dominican church in Vienna (Ecker 2010). In Innsbruck a similar sandstone (Hötting Breccia) decorated the façade of the cathedral in that city (Unterwurzacher and Obojes 2012), or in Lesser Poland (Małopolska), e.g. in Cracow Dolomite and Jurassic limestone from the region was used on the façade of the Jesuit church of St. Peter and Paul (Olesiak 2017). However, buildings were also faced with sandstones of different colors (against opinion Koller 1998), such as the traditional dark stone pietra forte from Florence (e.g. the façade of the church of Santi Michele e 
Gaetano), or even different colors, such as the sandstone on the façade of the Jesuit church in Antwerp.

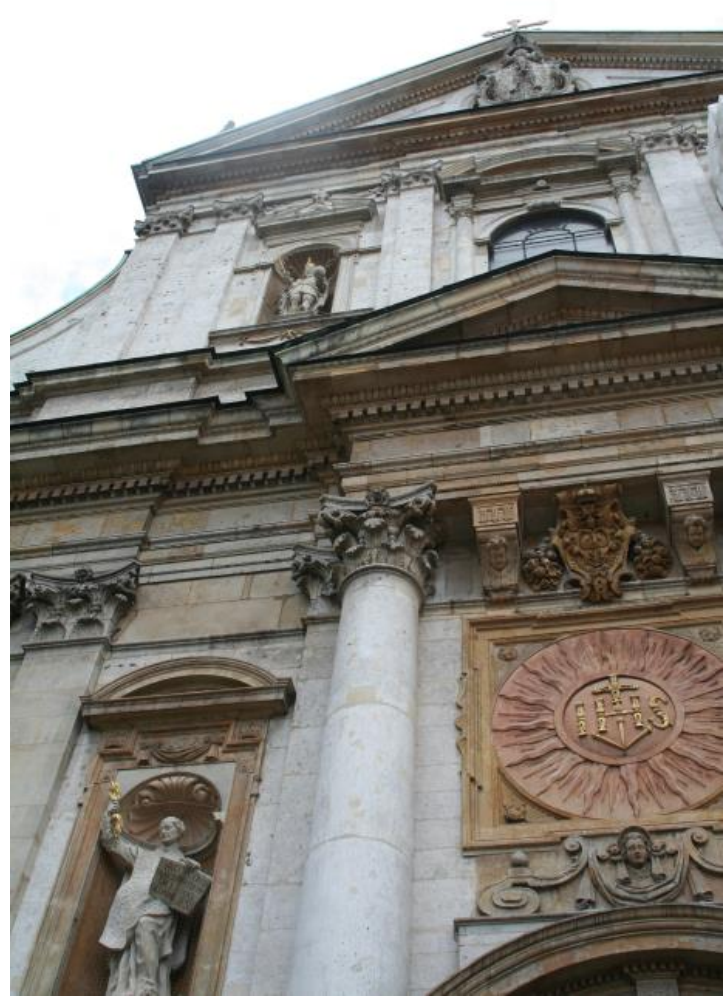

(a)

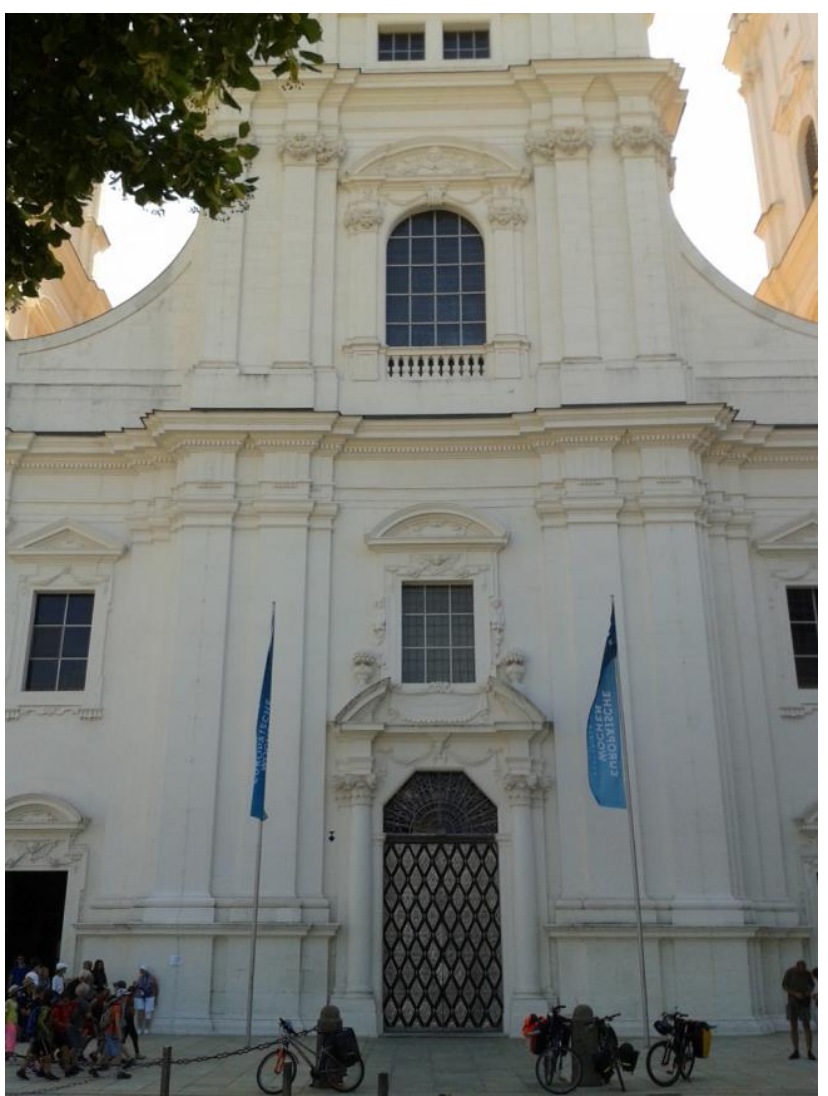

(b)

Figure 8. Monochromatic or semimonochromatic façade: (a) The façade of the church of Saints Peter and Paul in Cracow by Giovanni Trevano (1605-1619 to 1630) faced with Dolomite and Jurassic limestones from the region; (b) unification of the color of the natural light stone face entirely with a lime coating - the façade of Pasava Cathedral (1668-1693) by Carlo Lurago. Photos Bogna Ludwig.

Monochromatic color solutions of architectural orders were also designed in the late, dynamic Baroque, drawing on the ideas of Borromini and Guarini, Johann Lucas von Hildebrandt or architects from the extensive Dientzenhofer family and Johann Balthasar Neumann. Single-colored stone cladding was used: light sandstone, as in the case of the façade of the Bamberg Jesuit church (Gunzelmann 2016) designed by Georg and Leonhard Dientzenhofer (1686-1693), the façade of the monastery church in Michelsberg by Leonard Dientzenhofer (1696) and the abbey church in Neresheim by J.B. Neumann (1747-1792). The darker iron sandstone (Eisensandstein) on the façade of the abbey church in Banz by Leonhard and Johann Dientzenhofer (1698-1719) and the pilgrimage basilica in Vierzehnheiligen, built according to plans by J.B. Neumann (1743-1772), or even red sandstone, as on the façade of the Jesuit church in Heidelberg (1712-1759) and the façade of the Neumünster abbey church in Würzburg (1711-1716), the design of which is attributed to Johann Dientzenhofer. An exceptional solution for a façade is the uniform brick face of Palazzo Carignano in Turin by Guarino Guarini (1679), who consciously used this material in a manner customarily reserved for precious stones (Piccoli 2012). His imitations only appeared in the late Baroque designs of Bernardo Antonio Vittone. 


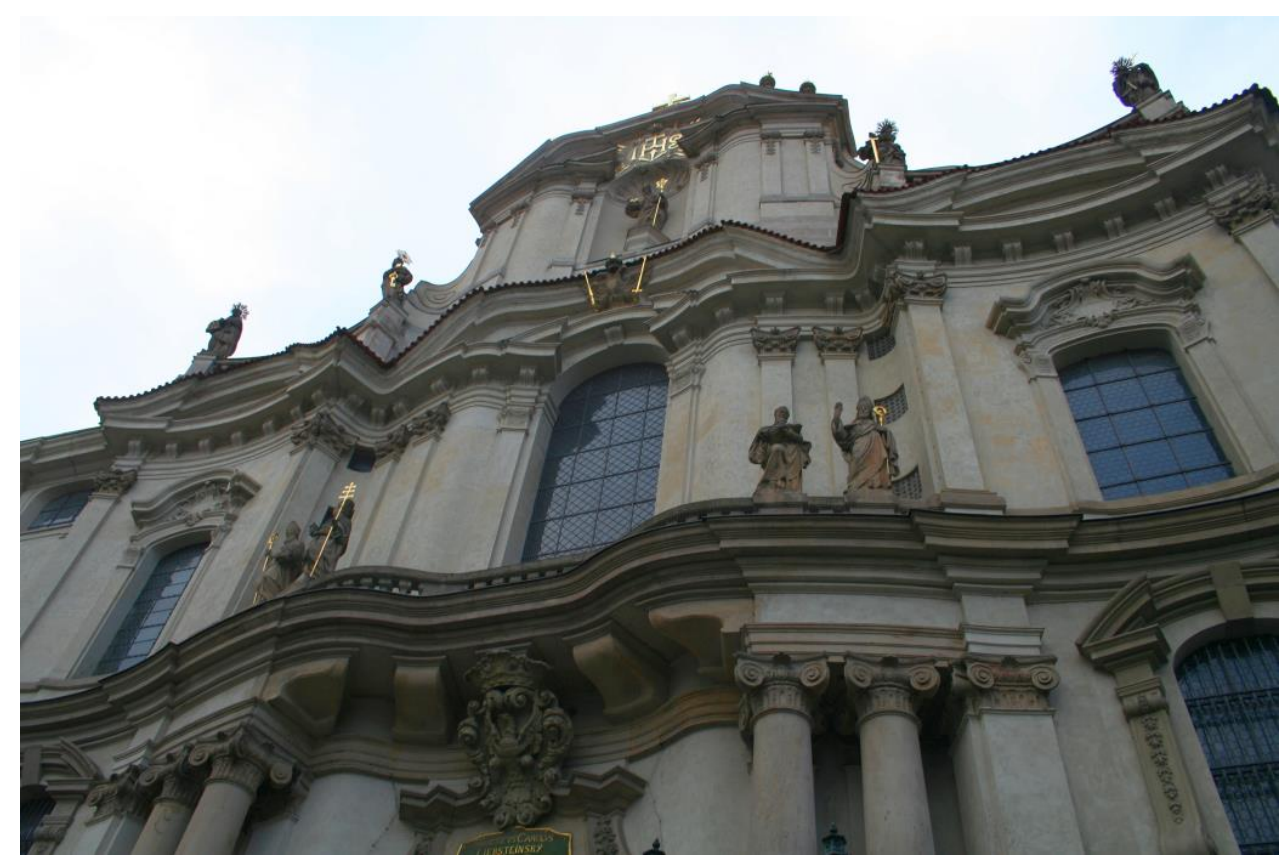

Figure 9. Strongly crimped entablature in the works of Christoph and Kilian Ignaz Dientzenhofer. Facade maintained in almost monochromatic colors with elements of various materials: stone and stucco. Facades of the churches of St. Nicholas on Mala Strana of Prague made in cooperation with the stonemason František Santini-Aichel. Photo Bogna Ludwig.

Façades were also covered with almost monochromatic colored elements made of various stone and stucco materials. Thus, the façade of Salzburg Cathedral (1614-1628) by Santino Solari was covered with so-called Untersberg marble using marbling and additions of light limestone. Sometimes a decision was made to unify the color of the natural light stone face entirely with a lime coating, as in the case of the façade of Pasava Cathedral (1668-1693) by Carlo Lurago (Hauck 2011). The court architects from Vienna used this façade finish particularly often. The façades of the Maria Trau Piarist Church in Vienna (1698-1719), designed by Lukas von Hildebrandt, or the so-called Reichskanzleitrakt at the Hofburg residence (1722-1726) (Koller 1997 and 2003) by the same architect, the Stadtpalais Prinzen Eugen (Winter Palace of Prince Eugene), executed from 1697 under the supervision of Johann Bernhard Fischer von Erlach, and then from 1708, of Hildebrandt, or the court church of St. Charles Borromeo (after 1716) designed by von Erlach were such developed. Sometimes darker ochre tones were chosen, as in the case of the exterior façades of the Esterház Palace (1663-1672) designed by F. Lucchese and executed by artists of the Carlone family. Christoph and Kilian Ignaz Dientzenhofer chose a lighter shade, as in the case of the façades of the Abbots' Church in Břevnov (1708-1740) or in Legnickie Pole (1719-1729, restored in the last renovation between 2014 and 2017), the churches of St. Nicholas in Mala Strana, St. Nicholas in the Old Town or St. John in Skalka, performed in collaboration with the stonemason František Santini-Aichel (Kotrba 1976). In some cases, slight tonal differences remained between stone elements and stucco or plaster. 


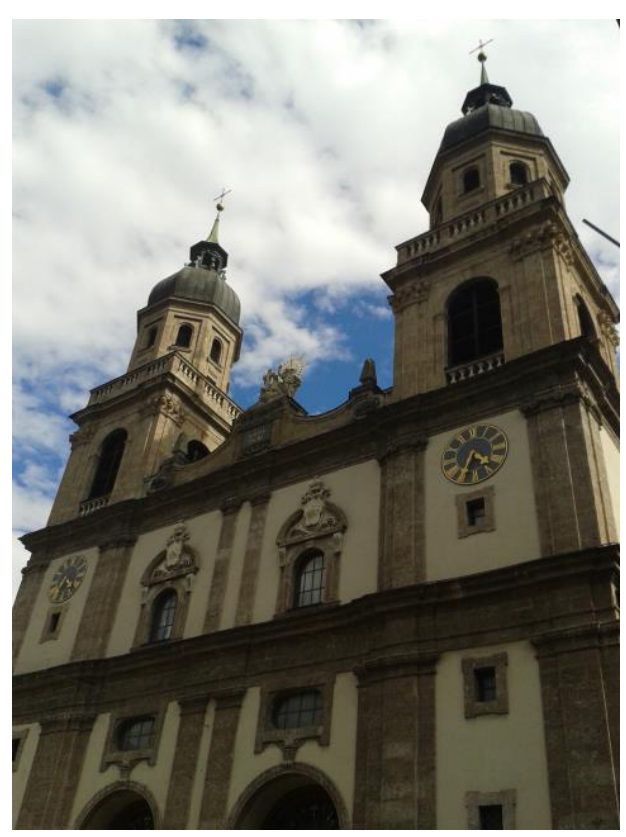

(a)

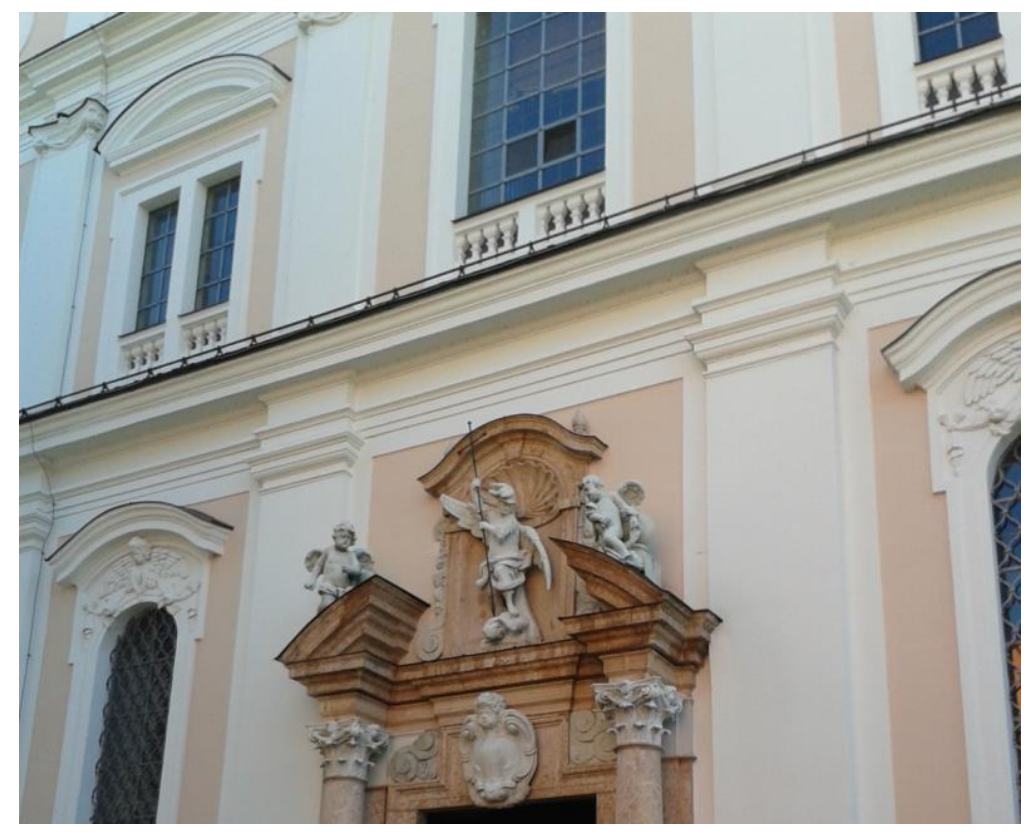

(b)

Figure 10. Monochromatic architectural order on colored walls: (a) creped entablature in sandstone architectural order the façade of the Jesuit church in Innsbruck (1627-1646); (b) white order on pink walls - the façades of the Jesuit church in Pasava (1677). Photos Bogna Ludwig.

Often, however, when stone construction elements were complemented with stucco ornaments or when only brick construction was used and covered with plasters and stuccowork, bichromatic solutions were introduced in colors. Usually, architectural details made of stone or stucco were unified in one color that stood out against a plaster or brick background, sometimes only with chapiters of pilasters made in another material. Plasters imitating the colors of stone or brick were used. Some solutions are associated with early Renaissance Florentine concepts, such as the façades of Jesuit churches in Innsbruck (1627-1646), where dark sandstone elements were exposed against a white background, or in Lucerne, where additionally granite capitals were used (Storemyr 2001). More subtle color combinations dominated - light, white, cream or ochre architectural detail, made of stone or its stucco imitation, appeared on the light background of plasterwork. Sometimes a white background was chosen, e.g., on the façade of the Jesuit church in Vienna (1624-1631) designed by Giovanni Battista Carlone and the façades of Gartenpalais Liechtenstein in Vienna by Domenico Egidio Rossi and Domenico Martinelli (1688-1700). More often a pastel-colored plaster was used: grey, as on the façade of the former convent church of Garsten (1685) designed and executed by Pietro Francesco Carlone and his sons, Carlo Antonio and Giovanni Batista, or on the church of St. Clare and St. Hedwig (Ursuline Sisters) in Wrocław, and even pink, as on the façades of the Jesuit church in Pasava (1677), designed by Pietro Francesco Carlone (renovation 2008), or green - on the façades of the Jesuit church in Linz (1669-1678) by Pietro Francesco Carlone and Carlo Antonio Carlone. Probably the most frequently used color of plaster was ochre yellow, as in the case of the walls of the University Church in Wrocław (1689-1698). At the beginning of the 18th century this two-colored scheme of polychrome of external façades with the use of yellow ochre or brick-red shades (Koller 2003b and 2007) began to dominate in southern Germany, which was influenced by the choice of color decoration for the Imperial Schönbrunn Palace designed by Fischer von Erlach. The stone (Eggenburger Kalksandstein) (Rohatsch 2005) elements of the architectural order on the façade of the imperial residence were plastered and painted in shades of white and set off against an orange-red brick background (realized by 1711; the façades were repainted the characteristic yellow in the 19th century) (Koller 2003c). 


\subsection{Color breakdown of the horizontal entablature. Distinguishing the colour of the frieze}

In classically elaborated order decorations an inscription frieze, often with gilded or dyed letters, sometimes replaced with ornamental belt, became an artistic element diversifying architecture. Such friezes can be observed both on façades and in interiors of the most famous Roman churches such as St. Peter's Basilica, churches of Il Gesù, S. Andrea della Vale or S. Ignazio. The frieze, like other elements of the entablature, was made of stone with engraved or carved surfaces. In solutions using bricks and stucco, which replaced those expensive materials, they were usually imitated with colors. Architectural orders treated in this manner became popular especially with the so-called Jesuit façade pattern. On most of the church façades designed according to this model, inscription friezes were used in the main entablature, similar to triumphal arches. Sometimes in the higher stores the frieze was ornamentally decorated, e.g. on the Jesuit church of St. Charles Borromeo in Antwerp (1626), where the superposition of three orders was used and accordingly, according to the rules, triglyphs and metopes, ornamental and console friezes were applied.

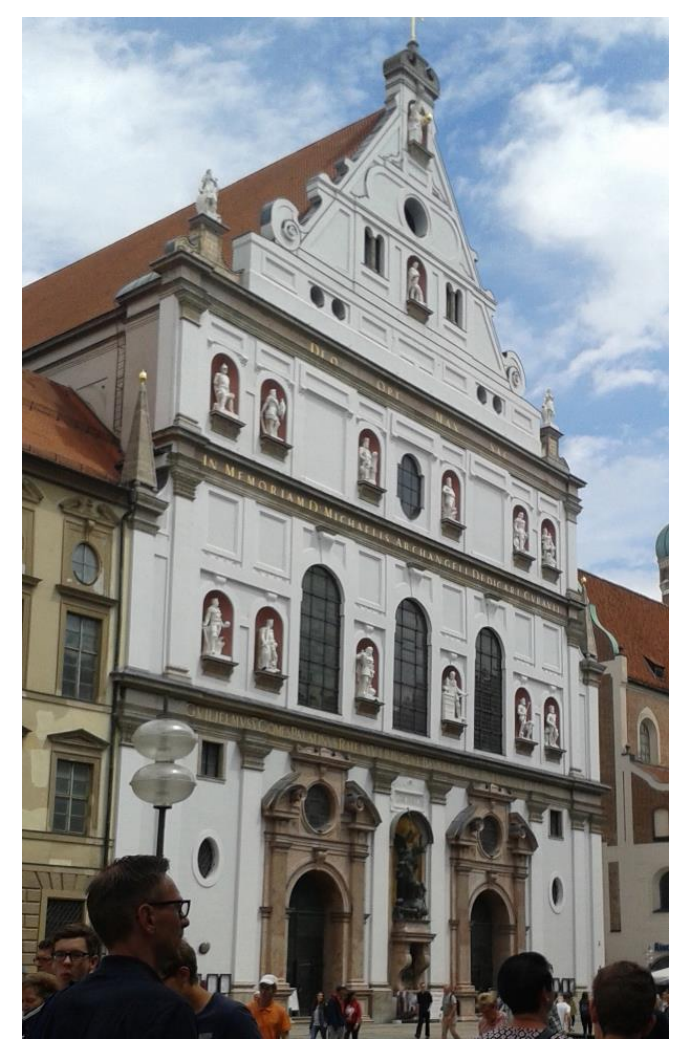

Figure 11. Entablature with a frieze of another type of stone covered with inscriptions. The façade of the Jesuit church of St. Michael in Munich (1583-1597), the largest Renaissance church north of the Alps. Photo Bogna Ludwig.

There were also solutions with friezes made of another type of stone, usually more intensively colored, e.g. red, as on the façade of St. Michael's Jesuit Church in Munich (1583-1597), the first significant work of the Renaissance in Munich and the largest Renaissance church north of the Alps: on the background of its white façade stone entablature of subsequent stores stood out with friezes covered with inscriptions (the façade was cleared of Baroque in the 1960s; the latest renovation in 2009-2013 restored the original color solutions) (Bertram 1961, Ertl 2019). In Milan, on the façade of the church of Sant'Alessandro in Zebedia (1623), Lorenzo Binago introduced a frieze with inscriptions in red pietra d'Angera (Segattini 2012a and b, Repishti 2003), and on the façade of the church in Certosa di Garegnano the same stone was used in three shades for the red cor- 
nice, the white architrave, and the yellowish frieze; in this color the walls were also finished.

In spite of the preference for monochromatic solutions in Mannerism and Baroque, varied color schemes were also constantly used in the decoration of architectural orders in interiors. This mainly concerned, apart from colorful backgrounds, the use of colorful friezes and shafts of supports. In designs based on classical patterns, backgrounds were still introduced to emphasize minor decorations of architectural detail such as cymatium or astragal. However, as in the case of monochromatic stone or plaster architecture, over time, with the Baroque influences, continuity and plasticity were sought after, reducing and simplifying ornamental forms in favor of architectural profiles characterized by rich chiaroscuro.

As a sculptor and interior decorator, Bernini appreciated the possibility of shaping expression through color effects. He combined precious marble and travertine materials and complemented them with stucco (Progetto di intervento 2015). He used colorful wall cladding, colorful column bases made of precious marbles, while in the case of the entablature, like the early Renaissance artists, he limited himself to using white or cream cornices and architraves, and only colorful friezes. He was particularly fond of the Cottanello marble (reddish-brown or orange) (Funiciello and Mattei 1991, Gasparini and Pensabene 2017), known as the material for the pillars of the columns of St. Peter's Basilica, which gained popularity again at that time. He used it in the form of a colorful orange-brown frieze between the white profiles of the cornice and the architrave in the decoration of the Cornaro chapel (works lasted until 1651), red in the interior of the church of S. Andrea al Quirinale (1658-1670), or red brown in the casing of the tomb of Pope Alexander VII (executed by his collaborators in 1672-1678) (Koortbojian 1991, Bernstock 1988). And in Sant'Agnese in Agone (1666-1668), he applied grey-blue frieze, and red shafts of columns. During this period also in interior decoration in the form of stucco, colored uniform or ornamentally decorated colored friezes were used, e.g. in the case of marbled and stuccoed interior of the church of Ss. Biagio e Carlo ai Catinari in Rome, probably by Domenichino (the author of the frescoes on the dome at the same time, 1627-1630), where an ochre frieze appeared in the main order, and in the entablature under the dome an inscription frieze with gold letters on a blue background (Eures Arte 2013). Such color schemes were adopted with the development of marbling techniques, at first mainly used for furnishings, then more and more commonly for wall decoration, including the finishing of the surface of order elements: column shafts and pilasters, but also colored friezes and wall backgrounds.

Colorful friezes made of marble or marbling were used in most architectural altars. Throughout the Baroque period they also appeared in interiors, both sacral and secular. Such solutions were realized as often as monochromatic, usually used with white stuccowork (Kurzej 2018). In many of his designs for altars and interiors they were used by Carlo Rainaldii (1611-1691), as in the case of the interiors of the churches of Sant'Agnese in Agone (1653-1657), S. Maria in Campitelii, S. Antonio dei Portoghesi or the chapel of the Spada family in the church of S. Maria in Vallicella. Some of the better-known architectural decorations of the interiors are works by Andrea Pozza, who, for example, applied colorful decorations to complete the chapel of St. Ignatius in the Il Gesù Church. The contractors were specialists from the northern Italian regions. Their services were highly valued in the 18th century. Late baroque and rococo interiors were decorated with rich marble or marbled decorations, and in the entablature there usually appeared stones intense in color or their imitations in the friezes. This is how the interiors of large churches were decorated, such as the imperial church in Vienna of St. Charles Borromeo, or Cistercian churches such as the church in Melk, the municipal monastic churches such as St. Nicholas in the Mala Strana in Prague, or richly decorated private and court chapels such as the Hofkirche in the palace of St. Peter and Paul in Prague. These include the Hofkirche at Würzburg Palace (1735-1743), designed by Lucas von Hildebrandt, or the Asamkirche in Munich, as well as representative rooms, monastic refectories and libraries such as those at Altenburg Abbey. 


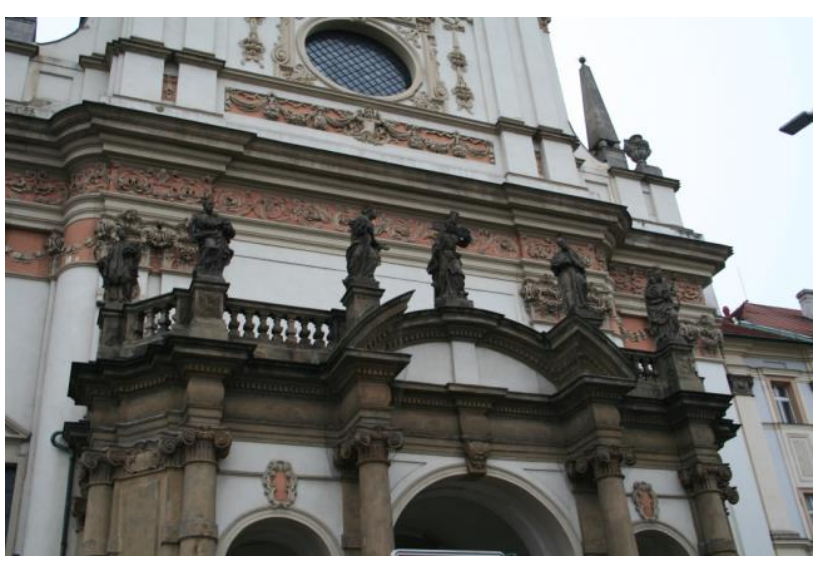

(a)

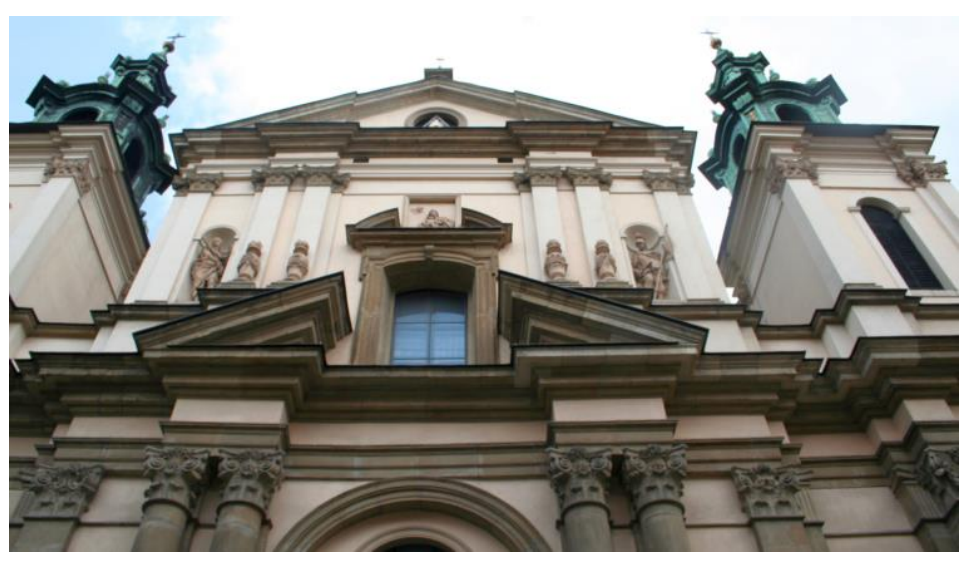

(b)

Figure 12. Entablature with a frieze of another type of stone or stucco: (a) colorful ornamental frieze in Carlo Lurago's architecture. Fragment of the façade of the church of St. Ignatius in the New Town in Prague (1665-1670); (b) St. Anne's Collegiate Church in Cracow, with cream-colored walls with sandstone and limestone detail (Tylman of Gameren 1689-1695). Photos Bogna Ludwig.

When various materials were used for wall structures and their plaster, stucco and paint finishes, and particularly when materials for the entablature were varied, it was common to treat the frieze, and sometimes also the shafts of the supports, as a background, contrasted with cornices, architraves and chapiters. In the most frequently introduced two-color systems, cornices, architraves and chapiters were made in one color of natural stone or one color of paint, and their background and the frieze area in another color. Both in Mannerism and early Baroque, slight chromatic differences were used. In one of his first architectural works, the façade of the church of S. Bibiana in Rome (1624-1626), G.L. Bernini used such an arrangement with a light sand color of plaster in the frieze area between the travertine cornice and architrave and the same on the shafts of pilasters (Ticconi 2020). Fr. Borromini designed the same color scheme for the façade of the Oratorio di San Filippo Neri in Rome (1637-1667), using cheaper techniques, due to the requirements of the monastic rule, of a brick structure finished with stucco and plaster (Argan 1955, Portoghesi 1967). This was also how Francesco Maria Richini (Ricchino) arranged the colors of the façades of churches in Milan after his stay in Rome (churches of San Giuseppe, Santa Maria alla Porta 1652). Earlier he had chosen color compositions closer to Milanese Renaissance traditions; with red cornices and architraves, as on the façade of the church of Santi Giacomo e Filippo in Pavia (1626). The architect-decorator Carlo Lurago, a native of the Como region who moved to Bohemia, used rich stucco detail in friezes and on chapiters, as on the façades of the Prague churches of the Most Holy Saviour in Clementinum (1638-1648) and St Ignatius in the New Town in Prague (1665-1670). In the latter case, according to a recent restoration, the detail was very colorful. In Tirol, entire façades were often polychromed in white and the architectural order was decorated in yellow with an isolated white frieze, an example being the pilgrimage church near Salzburg Maria Plain, designed by Giovanni Antonio Dario with a façade completed in 1674. On the façade of the church of St Teresa in Vilnius (1654), whose design is attributed to Constantine Tencalla, from the Ticino region, the architectural order with stone capitals is distinguished by white belts of cornices and entablature and a dark frieze, now grey, and in this color, slightly lighter, the shafts of the pilasters or St. Anne's Collegiate Church in Cracow, with cream-colored walls with sandstone and limestone detail (Tylman of Gameren 1689-1695). 


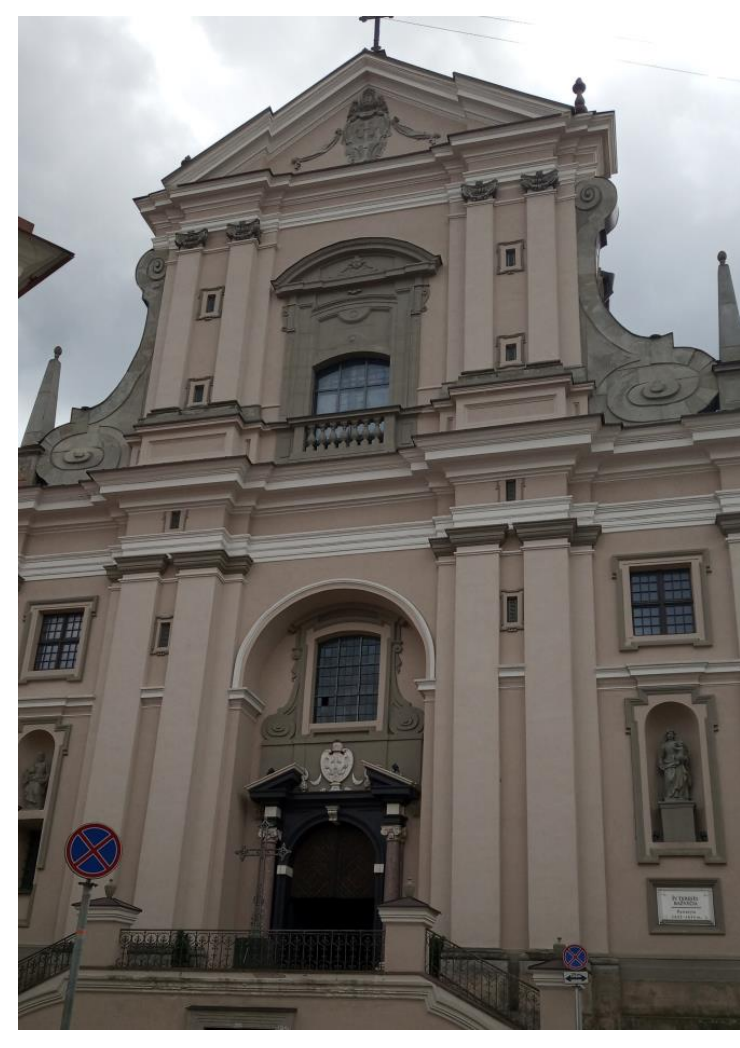

(a)

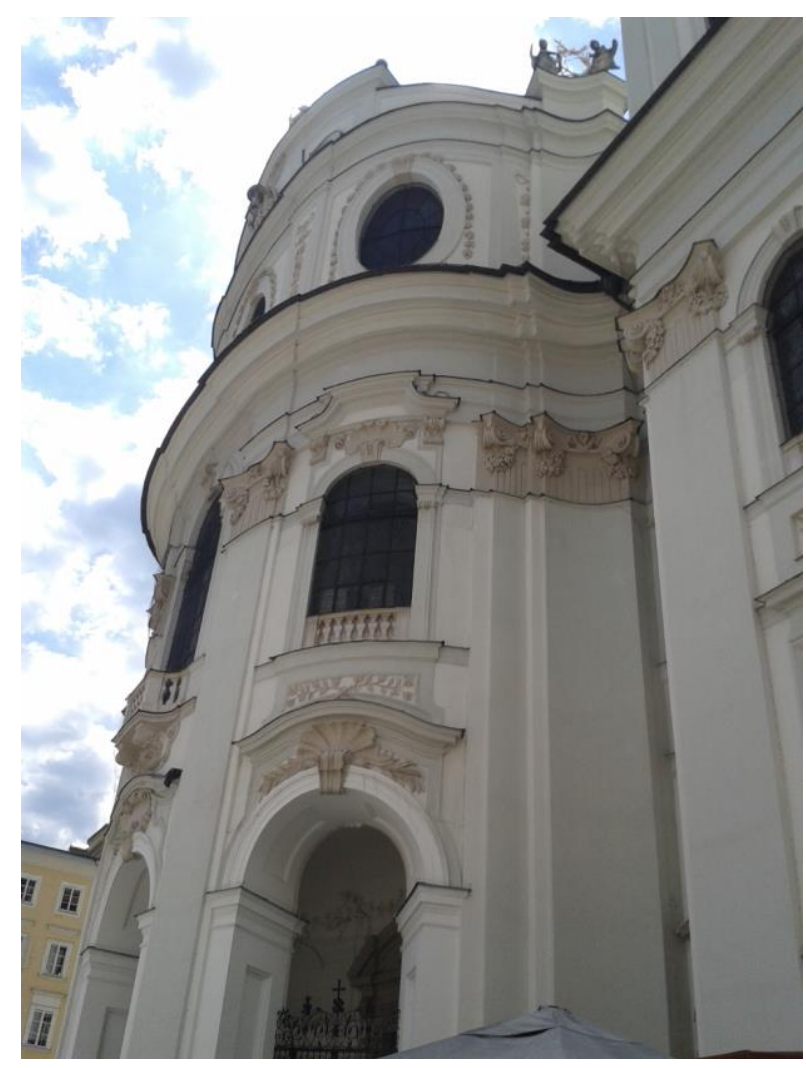

(b)

Figure 13. The architectural order with stone chapiters is distinguished by white stripes of cornices and architrave and a darker frieze: (a) the façade of the church of St. Teresa in Vilnius (1654) attributed to Constant Tencalla; (b) a grey order, light background and stucco decorations - the Kollegienkirche (Collegiate Church) by Johann Bernhard Fischer von Erlach (1696-1707). Photos Bogna Ludwig.

In the eighteenth-century Baroque, as mentioned, architects, especially Viennese court architects, most often used uniformly colored entablature, and more often whole façades in white or cream. However, Johann Bernhard Fischer von Erlach, when designing the façades of the churches in Salzburg, used a subtle two-tone arrangement with a frieze in the color of the walls, in the case of the façade of the Holy Trinity Church (1694-1702) - a white order on a light grey background, and the Kollegienkirche (Collegiate Church) (1696-1707) - a grey order, light background and stucco decorations (Koller 1998). A similar solution was probably proposed for the façades of the Church of St. John of Nepomuk in Prague-on-the-Hradany (1720-1729) and St. Magdalene in Karlovy Vary (1732-1736) by Kilián Ignác Dientzenhofer. The façade of the Priesterseminarkirche in Linz, designed by Johann Lucas von Hildebrandt (1718) and completed by the builder Johann Michael Prunner in 1725, was painted in equally subtle but warm tones with a white background and friezes in this color. The monastery church in Jablonné (Gabel, 1699), designed by Hildebrandt, was instead given a colorful façade with red cornices and architraves embracing white friezes and grey pilaster shafts (perhaps a contribution by Domenico Perini, who completed the construction). In the Asam brothers' designs, for example, the façade of their church in Munich, the so-called Asamkirche (1733-1746), was decorated with marbled friezes, the orange color between the white elements of the cornice and architrave in the main entablature, and the other way round, white between the red stripes of the order profiles in the torn tympanum (Reichwald 1976). Another façade of the Maria de Victoria Church in Ingolstadt, built according to their concept, was similarly colored. Such two-colored combinations within the entablature and usually different colored shafts of supports were used by late Baroque Italian architects, e.g. in Rome: Giuseppe Sardi - Church of S. Maddalena (1735), in Naples: Luigi Vanvitelli, Ss. Annunziata (after 1757), and Ferdinando Fuga - church of dei Girolamini (1780), Basilica di Santa Maria degli Angeli a Pizzofalcone (2nd half of 18th century), in Turin: Carlo 
Juvarra - Church of Santa Cristina, (1715-1718). Juxtapositions with sand background and white elements typical of South Germany and Lower Austria were used as on the façades of the monastery in Klosterneuburg (confirmed according to the renovation of 2013) (Ecker 2013), repeated the other way round, with colorful architectural details, sand yellow on a white background as on the façades of the palace in Wilanów (Jaskanis 2011) or orange-pink on Basilika Maria Dreieichen (1733) near Mold, or the parish church in Schwechat (1765) in Lower Austria (Koller 2007). There were also examples of façades using shades of green, as on the façade of the Fürstenfeld monastery church (1701-1747, Giovanni Antonio Viscardi, Johann Georg Ettenhofers).

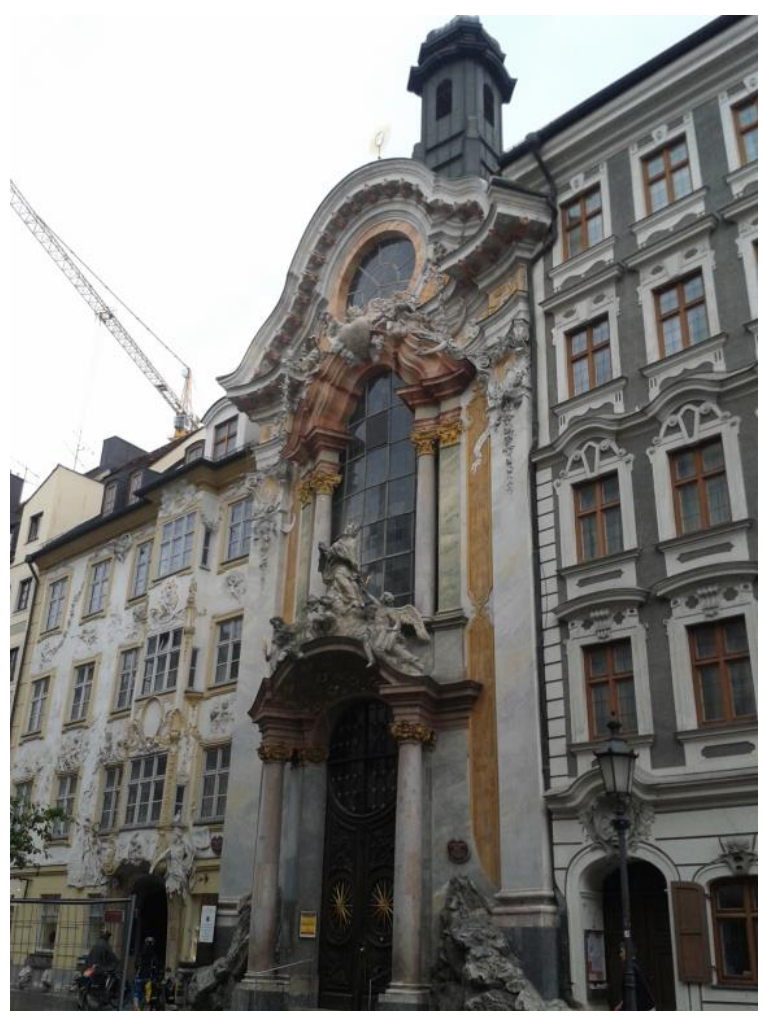

(a)

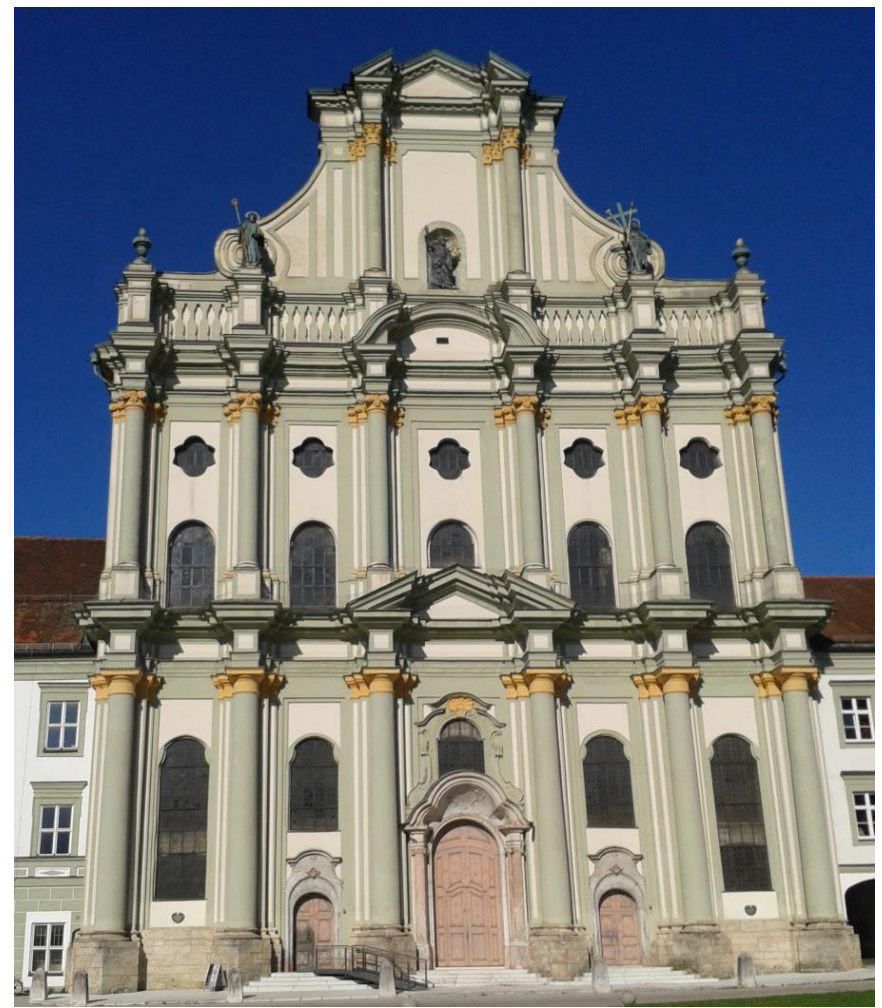

(b)

Figure 14. Two-color entablatures: (a) made in the marmorisation technique - the façade of the church of St. John of Nepomuceno in Munich, the so-called Asamkirche (1733-1746); (b) colored in shades of green - the façade of the monastery church Fürstenfeld by Giovanni Antonio Viscardi and Johann Georg Ettenhofers (1701-1747). Photos Bogna Ludwig.

In some circumstances, architraves were also used in a different color than the rest of the entablature elements, which usually resulted from the difference in the material. Initially, this was the case with multi-colored elements of entablature in continuation of Renaissance and Mannerist solutions, e.g. in Milan, where differently colored stone elements, red, yellow and white, were used. Similarly it was imitated in painted entablature e.g. in the case of architectural order in Henryków monastery. A few examples can also be found in the late Baroque. Probably due to the material used, especially spolia, a distinctive colorful architrave was introduced on façades at that time. Examples from Catania can be invoked here, a granite architrave in the Cathedral of S. Agata or local light stone, the so-called pietra giurgiulena (pietra bianca di Siracusa), in the church of Santa Maria dell'Elemosina. 


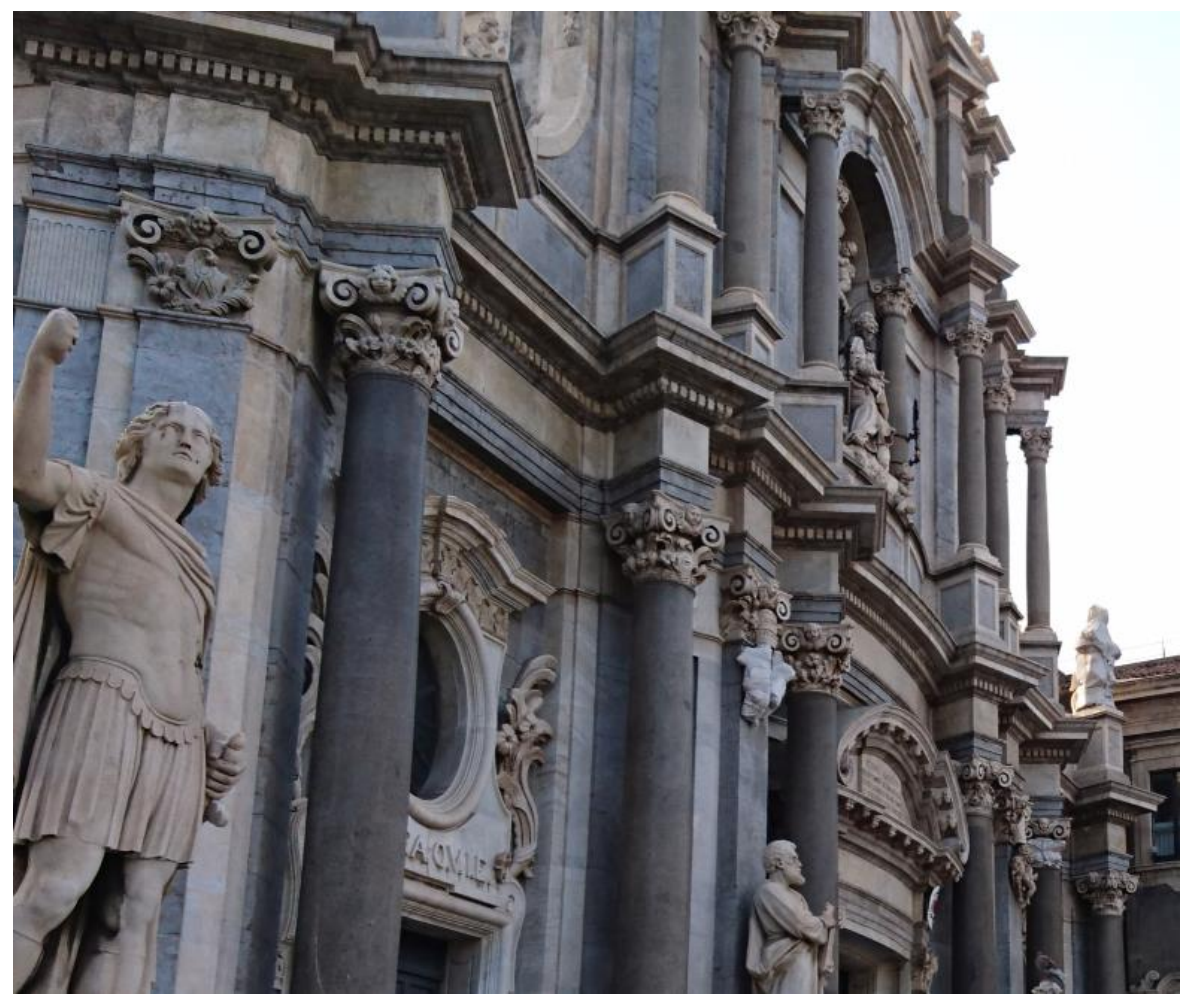

Figure 15. Due to the material used, especially spolia, a distinctive colorful architrave was introduced on façades a granite architrave in the Cathedral of S. Agata in Catania. Photo Sebastian Wróblewski.

\subsection{Color breakdown of the frieze in vertical arrangement. Colors of pseudo-imposts}

Changes in architectural dynamics during the late Renaissance, Mannerism and early Baroque consisted in a transformation of the balanced layout in favor of bivalent composition, and then the predominance of verticalism. It was largely connected with the breaking of the optical continuity of the entablature, embattled above the supports.

The layout with cornices protruding above the columns was already known from Roman architecture, especially from the triumphal arches, especially the best-preserved ones: Titus, Septimius Severus and Constantine. It was already used by Alberti (Tempio Malatestiano Rimini). In Rome, it appeared on the façade of the church of S. Maria del Popolo (1472-1477), and then on the church of S. Agostino in Campo Marzio (1483), which could confirm the authorship of both projects attributed to Baccio Pontelli, who is also sometimes associated with a similarly designed entrance façade of the Turin Cathedral. This solution of the entablature became more widely known thanks to the inventories of Giuliano da Sangallo (c. 1445-1516) and Antonio Da Sangallo il Giovane (1484-1546). It was often introduced in architectural casings of tombstones and altars from the turn of the 16th century, e.g. in the works of Tullio and Antonio Lombardo in Venice, Andrea Bregno or Andrea Sansovino. They were implemented in architectural projects by Antonio Da Sangallo il Giovane (design of the façade of St. Peter's Basilica in Rome, 1519-1520, design of the façade of the church of San Lorenzo in Florence). Bramante had already proposed embattled entablature within the risalits in the Belvedere courtyard at the Vatican (Cortile del Belvedere, project 1504-1505, completed in the 1640s). It was a transformation of Alberti's idea of a network façade with a superposition of orders. Such a scheme of architectural division structure found wide application especially in French palace architecture (Chateau of Chambord, 1519-1547, façades after 1525, Domenico da Cortona, built until 1559, Chateau of Blois, 1519-1536) (Tanaka 1992).

From the very beginning of his designing activity, Michelangelo made use of embattled entablature, which strengthened the expression of forms. They appeared in the decoration of the inner façades of the New Sacristy and the enclosures of the Medici tombstones located there (erected until 1534) and the vestibule of Laurenziana 
(1524-1534). This treatment introduced a kind of structural unease, particularly in the case of the library vestibule, where the entablature was set back rather than forward above the columns in niches. Jacopo Sansovino used this solution, taken from triumphal arches, like many other sculptors of the period, in the architectural decoration of tombstones. He also introduced the motif based on the architecture of the Arch of Constantine with a strongly embattled entablature into the design of the Loggia Campanilia in Venice (1537-1549). Apart from the connection with typically Mannerist expression in architecture, such a structure could emphasize the vertical arrangement in the composition, and for this reason it was probably associated with Gothic forms. Such a choice was made in the façade design for Bologna Cathedral (c. 1545) by Giulio Romano and Jacopo da Vignola (Progetti 2014), who nevertheless used massive simple entablature usually with inscriptional frieze in the completed façades of new churches.

The architectural composition taken from triumphal arches, used in a similar application as in the case of the Roman Porta Pia designed by Michelangelo (1561-1565) and widely known thanks to the published inventory of Vignola, was also often applied in the arrangements of palace façades. The compositional solutions of triumphal arches became popular through the publications of Serlio and Palladio. In "I quattro libri dell'architettura" Andrea Palladio presented examples of façades composed on the basis of these patterns (Palladio 1581, L. II, p. 9). The architect himself also used them in projects such as the Teatro Olimpico and the Loggia del Capitanio, as well as the Palazzo Valmarana in Vicenza (1565).

However, the greatest significance for the spread of the triumphal arch composition in monumental architecture had the model of the church façade in the form of the front of the Jesuit church Il Gesù in Rome (Giacomo della Porta, 1573-1580). The architectural design of this temple was one of the effects of the discussion during the Council of Trent, undertaken, among others, in connection with the rebuilding of St. Peter's Basilica, on the functionality and symbolism, and the corresponding spatial solutions of the church. It resulted in guidelines developed by Charles Borromeo (Borromeo 1572, Blunt 1956, Krasny 2017). Trying to find artistic means that were closest to the ideas of Cardinal Borromeo, it is worth noting Pellegrino Pellegrini called Tibaldi (1527-1596), the architect who was for a long time his collaborator. Tibaldi became the author of several churches in and around Milan, as well as part of the decoration of the Milan Cathedral. His main artistic explorations were based on the method of decomposition of orderly elements, the use of anamorphosis, a new spatial organization of interiors and the individualization of urban decorum within façades (Tafuri 1981). He often used embattled cornices in façade designs in the manner proposed by Michelangelo (San Fedele Milan 1569; S.S. Gervasio e Protasio, Parabiago, 1570, executed after 1610; San Gaudenzio Novara, 1577; Madonna dei Miracoli Saronno, 1583; Milan Cathedral façade design 1580). Other heirs to Michelangelo's ideas, such as Bernardo Buontalenti in Florence (façade of the church of Santa Trinita, 1592-1594), used similarly expressive entablatures.

Such a structural solution became almost a standard adopted in the design of all Jesuit church façades, but also other religious and diocesan churches. In Italy, it is possible to list façades of Jesuit churches composed in this way, starting from the south, e.g. Palermo del Gesù (1603-1607, reconstructed by N. Masuccio, project by G. Tristono) (Abbate 2001), in Rome S. Ignazio, (after 1626, around mid-16th century, Alessandro Algardi), in Reggio Emilia San Giorgio (1638), or the sanctuary Santa Maria della Porta in Milan (1652, Ricchini). In the Spanish Niederlands, close imitations were used on the façades of the Jesuit churches in Antwerp (1615-1621, 1626), Brussels (after 1621, now demolished), Bruges (1619-1642), and Leuven (1650-1666); the layout of the architectural order was also designed in this way for brick-faced architecture, as on the façade of the Jesuit church in Saint Omer (1615-1640) (Acker 1972, Snaet and De Jonge 2012). Within the empire, Jesuit churches in Vienna (1623-1627) and Innsbruck (1627-1646), for example, were decorated in this way. They were also used in combination with Gothic forms, as on the façade of the Jesuit church, now cathedral, of S. Marie Himmelfahrt in Cologne (1618-1678). 
The activity of Northern Italian builders contributed to the spread of such architectural solutions also in other Central European countries, e.g. the Republic of Poland. J.M. Bernardoni, who had already designed the stone façades of the churches of San Michele in Cagliari (1578, now rebuilt) and Santa Caterina in Sassari (1579-1609) in such a way, composed similar arrangements for Jesuits in Jarosław, Nieśwież (1586-1593) and Kalisz (before 1586) (Stankiewicz 2016), where triglyphs were incorporated into the frieze (Betlej 2018). The structure of vertical divisions on the façade of St Casimir's Church in Vilnius (1604-1618), destroyed in 1655 by Moscow army, was probably designed in the same way by G. M. Bernardoni and his student Jan Frankiewicz (Paszenda 2003 and 2010a), who later used the system in the Warsaw Jesuit church (construction of the church began in 1609, the façade probably dates to 1626) (Katalog zabytków 1993, Poplatek and Paszenda 1972, Paszenda 2010b). Similarly, Giovanni Trevano arranged the façade of the most famous Jesuit church in Poland, St. Peter and Paul Church in Cracow (1605-1619 to 1630). The embattled cornices were later used on almost all more impressive church façades in Poland, such as in Cracow in the case of the Bernardine Church, or in Poznan - the churches of the Jesuits, Bernardines, and Discalced Carmelites. This type of solution of the tectonics of the architectural order together with the increase in the number of vertical elements was very well suited to the continuation of the Gothic tradition still present in this area.

Similar factors were decisive for the widespread use of strongly embattled entablature in mature and late Baroque buildings in southern Germany, Austria, the Bohemia with Silesia, and the Commonwealth of Poland and Lithuania. The builders intensely verticalized the façade composition. This can already be seen in the work of Carlo Antonio Carlone (1635-1708) (Schmeller 1957), a native of Val'Intelvi, in his reconstructions of the façades of large monasteries, monastic, pilgrim and parish church façades in Upper Austria; in Schlierbach (1680-1683), and continued by Jacob Prandtauer in Sankt Florian (1686-1705), Christkindl, Kremsmünster and Garsten. Such increasingly expressive solutions can also be traced in the work of the Dientzenhofer family: Leonhard, for the Jesuit church and Neue Residenz in Bamberg, the façade of the monastery church in Schöntal (1707), and the monastery in Banz; Johann, for the façade of Fulda Cathedral and the monastery church in Banz; and Christoph and Kilian Ignaz, for the façade of the Church of St. John of Nepomuk on the Rock in Prague, St. Nicholas in the Mala Strana, the monastery church in Legnickie Pole, and the parish churches in Hořice and Nepomuk. Ottaviano Broggio (1660-1742) designed even more strongly orchestrated arrangements with repeatedly bent cornices on the façades of the churches of St Wenceslas in Litoměrice, the monastery church in Osek, St Adalbert in Ústí nad Labem and the façade and entrance gate of the monastery in Doksany (1697). Analogous compositions were used by late Baroque architects, including Italian artists inclining to Classicism, such as Domenico Rossi on the façade of the church of Santa Maria Assunta in Venice (1715) or Ferdinando Fuga - façade of S. Maria Maggiore in Rome (1741-1743), as well as artists from Germany and Central Europe, such as Balthasar Neumann (1687-1753), who strove to increase the dynamics of form, for example, in the façade of the Holy Trinity Pilgrimage Church in Goessweinstein (1730-1739), the Basilica of the Fourteen Holy Helpers near Bad Staffelstein (1743-1753) and the abbey church in Neresheim (1747-1792). Cornices protruding above supports appeared in almost all works of Pawel Antoni Fontana (1696-1765), who worked in the Commonwalth of Poland, e.g. on the façades of the churches of St. Anne in Lubartów (1733-1738), Nativity of the Blessed Virgin Mary in Chełm (1735-1756), St. Louis in Włodawa (1743-1757), designed by Franciszek Placidi: the Piarist Transfiguration of Our Lord Church in Cracow (1759-1761), the Brothers of Mercy Church of the Holy Trinity (1751-1758), and the Church of St. Sophia in Polotsk (1738-1750) by Jan Krzysztof Glaubitz from Lithuania.

The embattling of the cornice changed the way the frieze was made, it was necessary to strengthen a fragment of the frieze above the capitals; the frieze was made entirely of stone or strengthened in this part where the frieze was fragmented. Initially, efforts were made to obliterate the traces of differentiation. According to the late Renaissance, Palla- 
dian tradition and later the models of Roman architecture, the white or light color, imitating the natural colors of stone, was preserved within the whole entablature by means of unification with plaster and polychrome. However, with time the introduction of stone elements within the frieze that differed from the rest of the plastered frieze resulted in a change of color of these fragments. Such construction techniques appeared in northern Italian regions, Lombardy. It may have resulted from the implementation of local construction traditions to classical architectural solutions but most of all from saving precious building material which in that region was stone.

This is how local Lombard architects, active in the first half of the 17th century, executed the façades according to their designs. F.M. Richini, the author of various versions of the Milanese Cathedral façade designs, based on Roman models he had studied during his travels, introduced this type of structure into the design of the façade of the church of San Giuseppe (erected between 1629 and 1630), described as the first example of Milanese Baroque, and later into the façade of the church of S. Martino in Veduggio con Colzano (1642, well visible after conservation in 2012) (Balestreri 2017, Wittkower et al. [1958] 1999, p. 86). His collaborator and successor on the Milan Cathedral site, Carlo Buzzi, followed a similar approach in numerous façade designs for churches in Milan and the surrounding area (S. Ambrogio in Merate, Santo Stefano Maggiore in Milan, San Bartolomeo Loggio in Valsolda).

At the same time, such constructional and design concepts were applied by Jesuit architects who based their projects on the Tibaldi model. This is best seen in the case of the retention of unplastered stone elements, as in the case of the façade of the Jesuit church in Lviv (ca. 1630) by Giacomo Briano (Paszenda 1972, 1973 and 1999, Betlej 2002), a Jesuit from Modena, where the structural elements, including the reinforcement of the frieze over the chapiters of the Corinthian pilasters, were made of dark stone, contrasting with the white of the plastered walls (Wittkower et al. [1958] 1999, p. 97) (A 1). The architects and builders from Como and Ticino regions designed similarly. Here we can mention the work of stucco artists and builders of the Lurago family. On the stucco façades of the churches of San Giorgio (c. 1647-c. 1685) and San Barnaba (after 1660) (Iton 2018, Angelo 2018) in Modena, Antonio Loraghi (Lurago) (Pinto 2006, Bieri 2017) designed a composition with continuous vertical elements - in architectural orders, contrasting white on brick backgrounds above columns and pilasters in embattled entablature within the frieze, a type of impost, also white, was introduced, standing out against the background of the frieze matched to the color of plaster. His older brother Carlo Lurago, active in Lower Austria and later Bohemia, worked in the same way on church and monastery façades, but chose lighter, less contrasting backgrounds, as in the case of the pilgrimage church façade in Maria Taferl (1670-1671), the Church of the Assumption of the Virgin Mary in Hradec Králové (1654-1679) or the façade facing the river in Prague's Clementinum (1654-1679). 


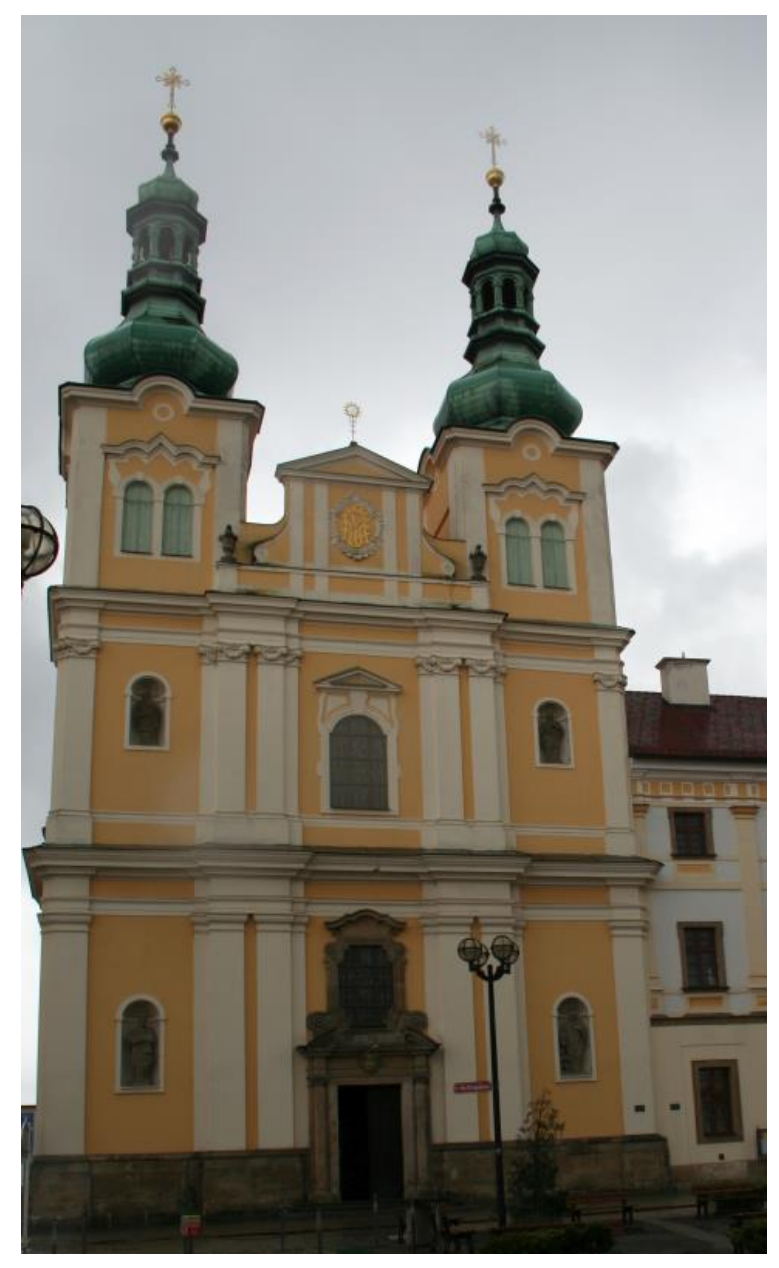

(a)

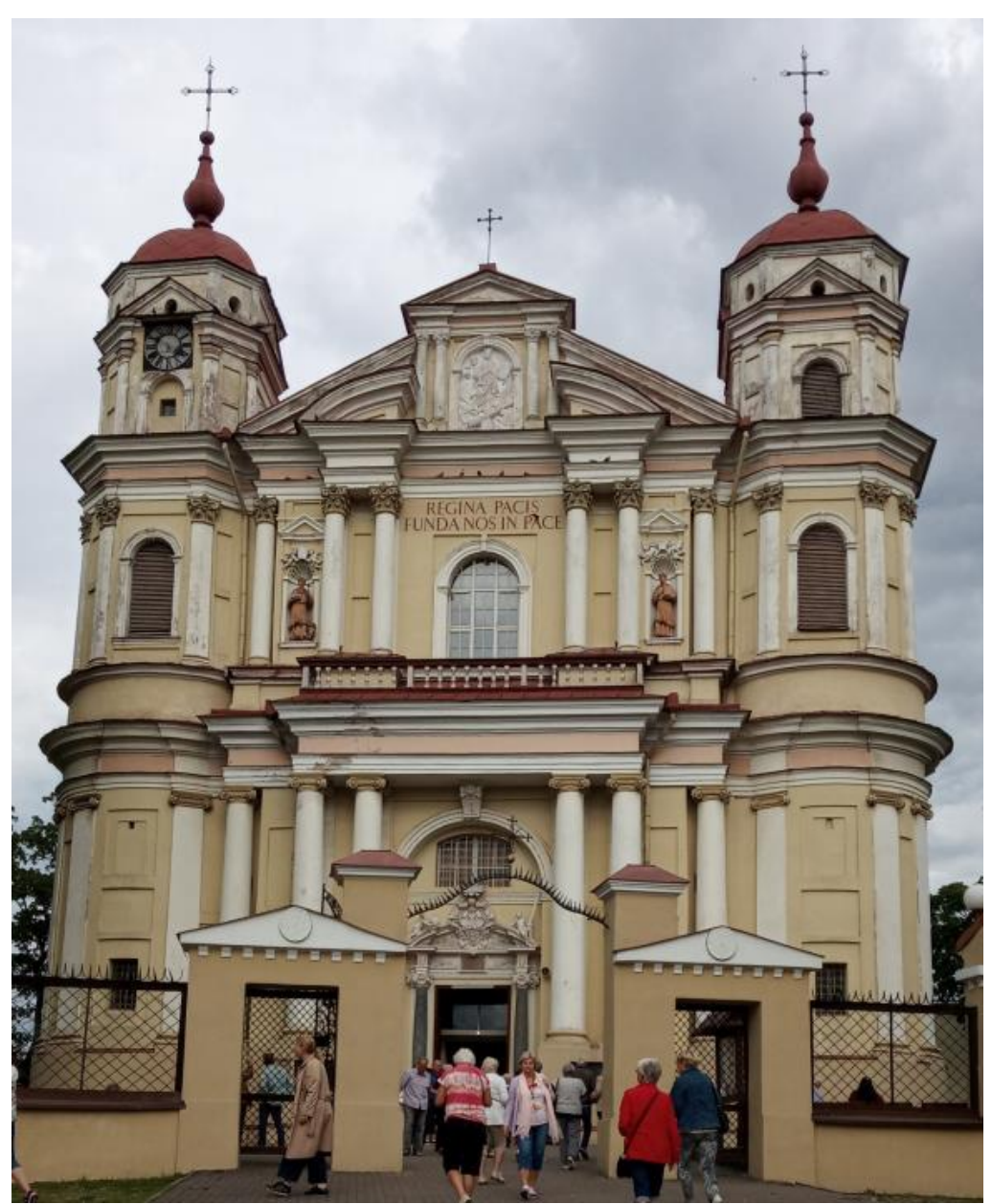

(b)

Figure 16. Composition with continuous vertical elements - in architectural orders: (a) the façade of the Church of the Assumption of the Virgin Mary in Hradec Králové (1654-1679) by Carlo Lurago; (b) the façade of the church of St. Peter and Paul on Antokol in Vilnius (1670s), according to the design of the Krakow architect Jan Zaor, probably modified by Giovanni Battista Frediani. Photos Bogna Ludwig.

The ideas of northern Italian artists were continued by local builders who collaborated with them. This was the case with the façade of the Jesuit Church of St. Francis Xavier in Lucerne (1673-1677), which may have originally been designed by Tommaso Comacio of Roveredo in Grisons (Santi [2004] 2021), but was built by Michael Beer and Michael Thumb from the Austrian province of Voralberg to the east and completed by Jesuit Heinrich Mayer (Bieri 2012). It uses, as already mentioned, the Renaissance color scheme with the dark drawing of the stone order on the light background and the elements of the frieze above the pilaster chapiters are made in this dark sandstone. The same artists reproduced this design on the façade of the Premonstratensian church in Obermarchtal (1686). Collaborating with them, the Jesuit Heinrich Mayer also designed the façade of the church of his order in Soleure (Solothurn) in Switzerland (1680-1687) (Carlen 1981). Through such artists the solution spread further in Europe. Sometimes a version emphasizing even more the vertical arrangement of the façade's structure was chosen by resigning from the continuous architrave and frieze elements and replacing them with the impost, supporting the cornice above the pilasters' chapiters, as on the façade of the Am Hof church in Vienna (1662) by Carlo Antonio Carlone or some works by Czech Dienzenhofers.

The continuity of color in the elements of the vertical structure, i.e. the painting of the part of the frieze, discontinued above the pilasters, in the same color as the supports themselves, and thus distinguished from the background of the frieze itself, have been frequently reconstructed recently during conservation works and restoration of the color 
scheme of church façades. According to the research, such solutions were most often chosen by architects or, what is sometimes difficult to establish, builders from northern Italian and Swiss regions who cooperated with them. One can cite examples from the 1680 s to 1690 s erected throughout Central Europe from the region of Upper Austria including façades in Steyr: of the Dominican Marienkirche (1642-1644) and the Jesuit St. Michael's Church (1648-1677), the pilgrimage church of Heiligenkreuz near Kremsmünster (1687-1690), designed by Carlo Antonio Carlone, Lower Austria - e.g. from Vienna: façade of the pilgrimage church Mariahilf under the care of the Barnabites (until 1711) made on the basis of plans presumably originating from an Italian author, and built by Sebastian Carlone the Younger and stonemason Ambrosius Ferrethi (with coloring reconstructed in 2003) (Ecker 2003), Silesia - e.g. from Wrocław: façades of the churches of St. Jacob (St. Anne, 1686-1690), (maintenance works 2010) designed by the architect Sigmund Linder and St. Anthony (1685-1692), designed by an Italian architect, erected under the direction of the master builder Mateusz Biener of Wrocław (restoration works 2011), Poland - the façade of the church of the Oratorians near Gostyn (1675-1698), erected under the direction of the Italian architects Jerzy and Jan Catenazzi, the church erected for the Jesuits in Krasnystaw of St Francis Xavier, designed by Jan Ignacy Delamars (1697-1715) (Rusińska-Kurzątkowska 1956, Szewczyk and Bubicz 2020), the pilgrimage church in Święta Lipka (1687-1695) built (until 1730) or perhaps designed by Jerzy Ertlie (Paszenda 1993 and [1998] 2015), (restored to its original colours in 2010-2013) (Dzieciątkowska 2010), to Lithuania - e.g. the façade of the Church of Saints Peter and Paul in Antokol in Vilnius (1670s-1770s), designed by the Cracow architect Jan Zaor, probably modified by Giovanni Battista Frediani, who may have also designed a similar façade for the Trinitarian Church in that city (1694-1716) (Guttmejer 2019).

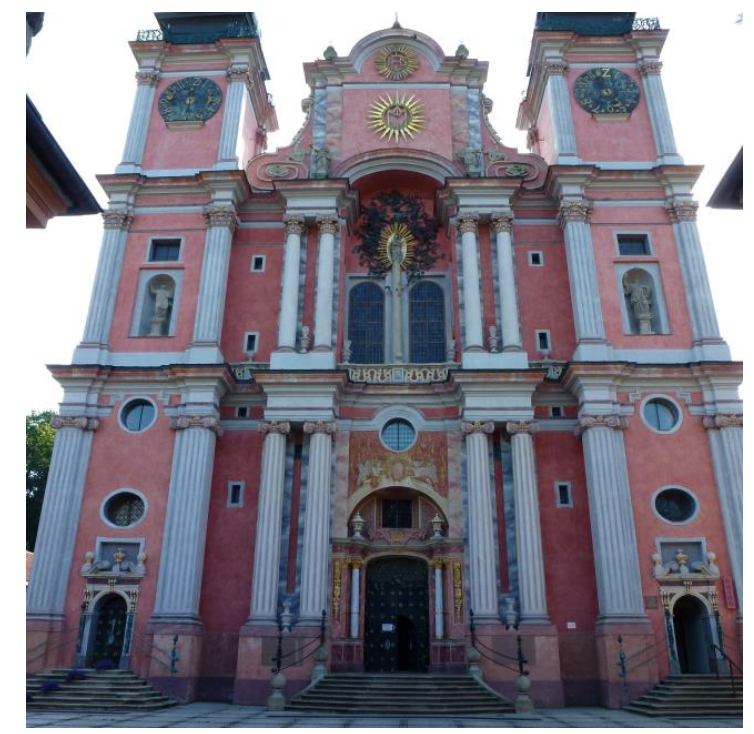

(a)

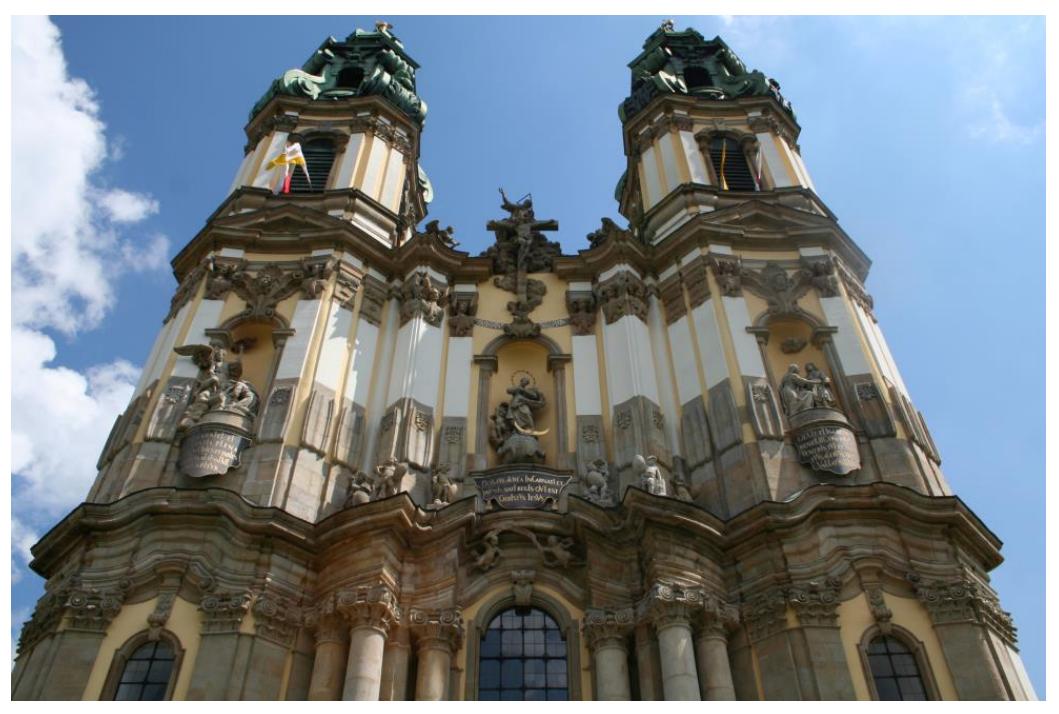

(b)

Figure 17. Continuity of multiplied elements of vertical division was emphasized by color: (a) the façade of the pilgrimage church in Święta Lipka (1687-1695) built and perhaps designed by Jerzy Ertlie; (b) the façade of the monastery church in Krzeszów in Lower Silesia (1728-1733). Photos Bogna Ludwig.

Simultaneously with the development of dynamics of architectural forms in the Baroque, compositions were often made vertical. It was connected with interest in Gothic heritage, present in works of Northern Italian Mannerists and their continuators, e.g. Borromini himself, taken up by Baroque artists working in territories with still strong Medieval traditions. It manifested itself in the use of architectural profiles referring to Gothic forms, sometimes with literal quotations (best seen in the works of e.g. J.B. Santini Aichel), but also in the use of structural solutions (e.g. Czech Dientzenhofers implemented a solution with buttresses inside). However, the most visible manifestation was accentuation of façades with strongly visible, often multiplied elements of vertical divi- 
sions - half-columns and pilasters or lesenes. Such solutions were of particular importance in the works of mature and late Baroque architects working in Bavaria, the Habsburg Empire, Bohemia and Silesia, and later their students and followers, who came to the Grand Duchy of Lithuania, such as Jan Krzysztof Glaubitz from Świdnica in Silesia.

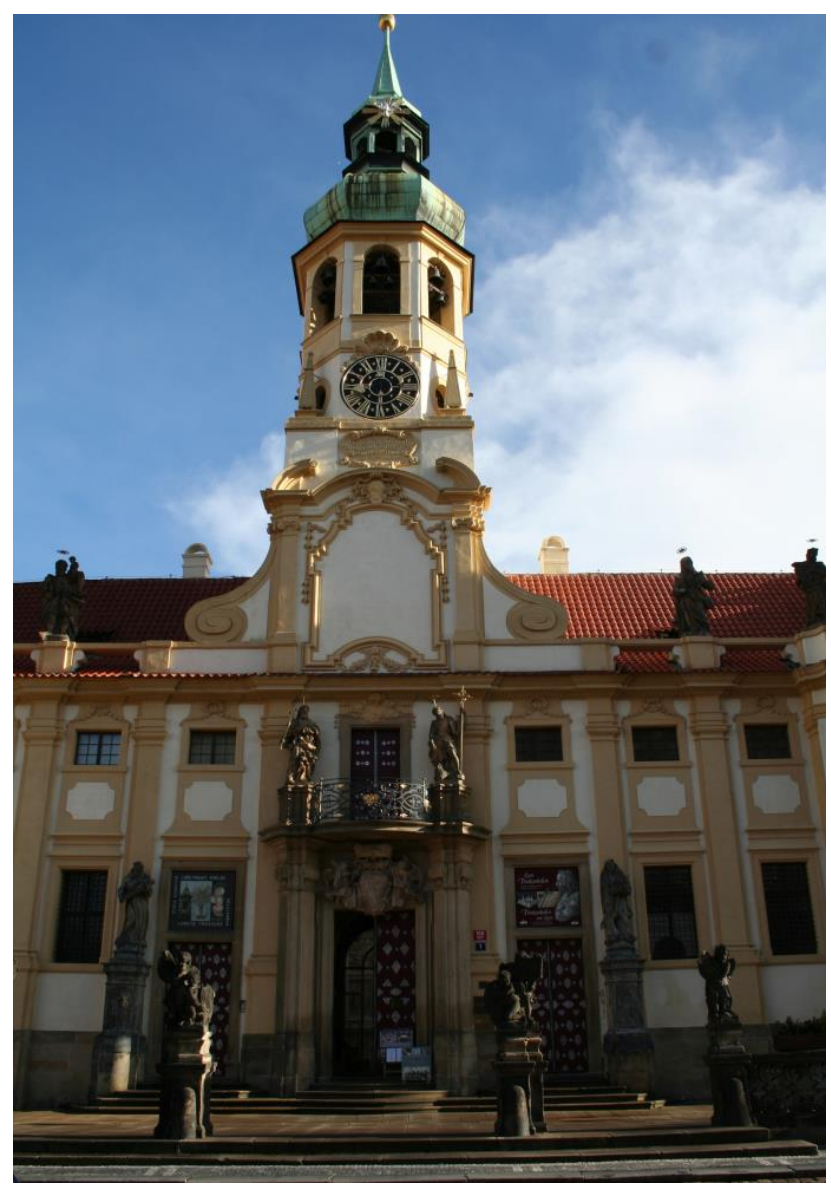

Figure 18. The monumental façade of the Loreto complex in Prague by Ch. and K.I. Dienzenhofer (1722-1726). Photo Bogna Ludwig.

The expression of the work shaped in this way could be highlighted by the discussed color scheme of the architectural order. The earliest examples of polychrome decoration of an entablature with a distinction of pseudo-imposts, different in color from the frieze, emphasizing the vertical composition, appear among the designs by Christoph and Kilian Ignaz Dienzenhofer on the façade of the monastery church of St. Joseph in Obořiště (1702-1711) and by Matthias Steinsell (Steindl) on the façade of the parish church in Laxenburg near Vienna (1703) (Ecker 2003). They use slightly contrasting juxtapositions with light detail and sandy ochre colors. The monumental façade of the Loretto ensemble in Prague, overshadowing the Church of the Nativity of Our Lord with the Loretto House (1722-1726) by the Dienzenhofer family, was performed in a similar layout using interrupted friezes and architraves (imposts) (Líčeníková 2017, Koberová 2017). However, in many works of artists or builders from this circle, such a solution of polychrome is reproduced on continuous, only crimped entablature, as in the case of examples from Lower Silesia: the façade of the monastery church in Krzeszów (1728-1733) (Ałykow 2014), Lubomierz (1728-1730, selected by master builder J.J. Scheerhofer), the parish church of St Valentine in Lubiąż, the former Benedictine selected Scheerhofer), the parish church of St Valentine in Lubiąż, the former Benedictine church of St Maurice in Legnica, designed by J. J. Scheerhofer, and the church of the Blessed Virgin Mary at the Cistercian monastery in Neuzelle in Lower Lusatia (c. 1730). Such polychrome arrangements of architectural order appear in the works of Jakob Prandtauer (1660-1726) on the façades of the abbey church in Melk (1711-1725) (Koller and 
Paschinger 1980, Koller 2010, Murczek 2017), the Carmelite church in St. Pölten, built by Matthias Steiner, and the church of the Cistercian nunnery in St. Moritz. Pölten, built by Matthias, the pilgrimage church in Sonntagberg (1718-1732) and the parish church in Wullersdorf (1725-1733), as well as on the large-scale façades of the Moravian palaces attributed to him in Jaroměrice nad Rokytnou with the Church of St. Margaret (1710-1735) and in Myslibořice. They can be found among the works of Hildebrandt and artists from his circle, as on the façades of St. Peter's Church in Vienna (1701-1733), possibly in its final form designed by Kilian Ignaz Dientzenhofer, the Trinitarian Church in Bratislava (1717-1727), designed by Franz Jangel and J.L. von Hildebrandt, St. Anne's Church in Pilsen, Bohemia (1717-1727) by Jakub Auguston, who probably also used similar designs for the façades of monasteries e.g. in Chotěšov, and palaces, the monastery church in Fürstenfeld by Giovanni Antonio Viscardi and Johann Georg Ettenhofer, the monastery church of St. Lawrence and St. Stephen in Innsbruck (1713-1719) by Georg Anton Gumpp (1682-1754), the church of the Brothers Hospitallers in Linz (1729-1732) by Johann Michael Prunner and the Lamberg palace in Passau (1724), all designed by this architect. This color scheme was also used by the Graz court architects Andreas Stengg and his son Johann Georg Stengg, for example on the façades of the Mariatrost pilgrimage church (1714-1724) and the Church of the Brothers Hospitallers in Graz (until 1740).

In addition to these two-color systems with light architectural details and wall backgrounds in ochre, sometimes beige, or the other way round, with darker details on a light background, we can also find three-color polychromes with the use of colors unprecedented in the earlier period, such as, for example, in the Lower Austrian pilgrimage church in Mariahilfberg near Gutenstein (1724-1727) where a pink frieze between the white cornice and architrave and grey pilaster shafts were used (Koller 2007). Occasionally there was a return to the Renaissance color scheme; with a red outline of order elements on a white background, as on the façade of St. Wenceslas Church in Vysočany (1734-1738) by O. Broggio (restored in 1998).

Such a color scheme of architectural order structure was commonly used by late Baroque and Rococo designers, such as Dominikus Zimmermann, Johann Michael Fischer or Jan Krzysztof Glaubitz. All façades of buildings, both public and sacred, designed by D. Zimmerman were painted to emphasize vertical articulation - e.g., the highly ornamental front of the town hall in Landsberg am Lech (1719), the pilgrimage church in Steinhausen (1729), or the more modest parish church in Buxheim (1729). Among Fischer's works with such an order painting using a two-color scheme of grey and white are the tower façades of the Church of the Holy Sepulchre in Deggendorf (1722-1727) and the monastery church of Marienmünster Dießen in Dießen am Ammersee (1731-1739), or, this time with a strongly contrasting ochre detail on a white background, the monastery church of St. Michael in Berg am Laim (1738-1751). The same color combination was used for the façade of the Premonstrantensian sanctuary in Wilten near Innsbruck (1751-1755), built according to plans by the Tyrolean architect Joseph Stapf. In J. K. Glaubitz's designs the continuity of multiplied elements of vertical division was emphasized by color in almost all façades of the Vilnius churches, e.g. the Church of St. John the Baptist and St. John the Evangelist (1738-1749), St. Catherine (1741-1744) or Holy Spirit Church (1753-1770). Similar solutions were applied by Antonio Paracca, who worked at the same time in Vilnius on the Basilian Monastery Gate, and the façade of the Missionary Church (1751-1756) (Karpowicz 2011), as well as by the Jesuit Paweł Giżycki, author of the façades of the Jesuit church in Krzemieniec (1731-1745), Stanislavov (1752-1763), and the Bernardine Monastery in Lutsk (1752-1789) (Betlej 2000a, b and 2003).

In Cracow, this polychrome effect emphasizing verticality first appeared on church façades by Antonio Solari, who redesigned the façade of the church of St Michael the Archangel and St Stanislaus the Bishop and Martyr on Skałka (1733-1749) (Lenartowicz 2003) (restored in 2019). A similar arrangement was used on the façade of the church of the Transfiguration in Łuków (1733-1762) by this architect. Also, on the front façade of the Piarist Church of the Transfiguration of Our Lord in Cracow (1759-1761) by Fran- 
ciszek Placidi (restored in 2007) (PPKZ 2012), similar in expression to the examples from Vilnius, the painting of the transfiguration was done in this way.

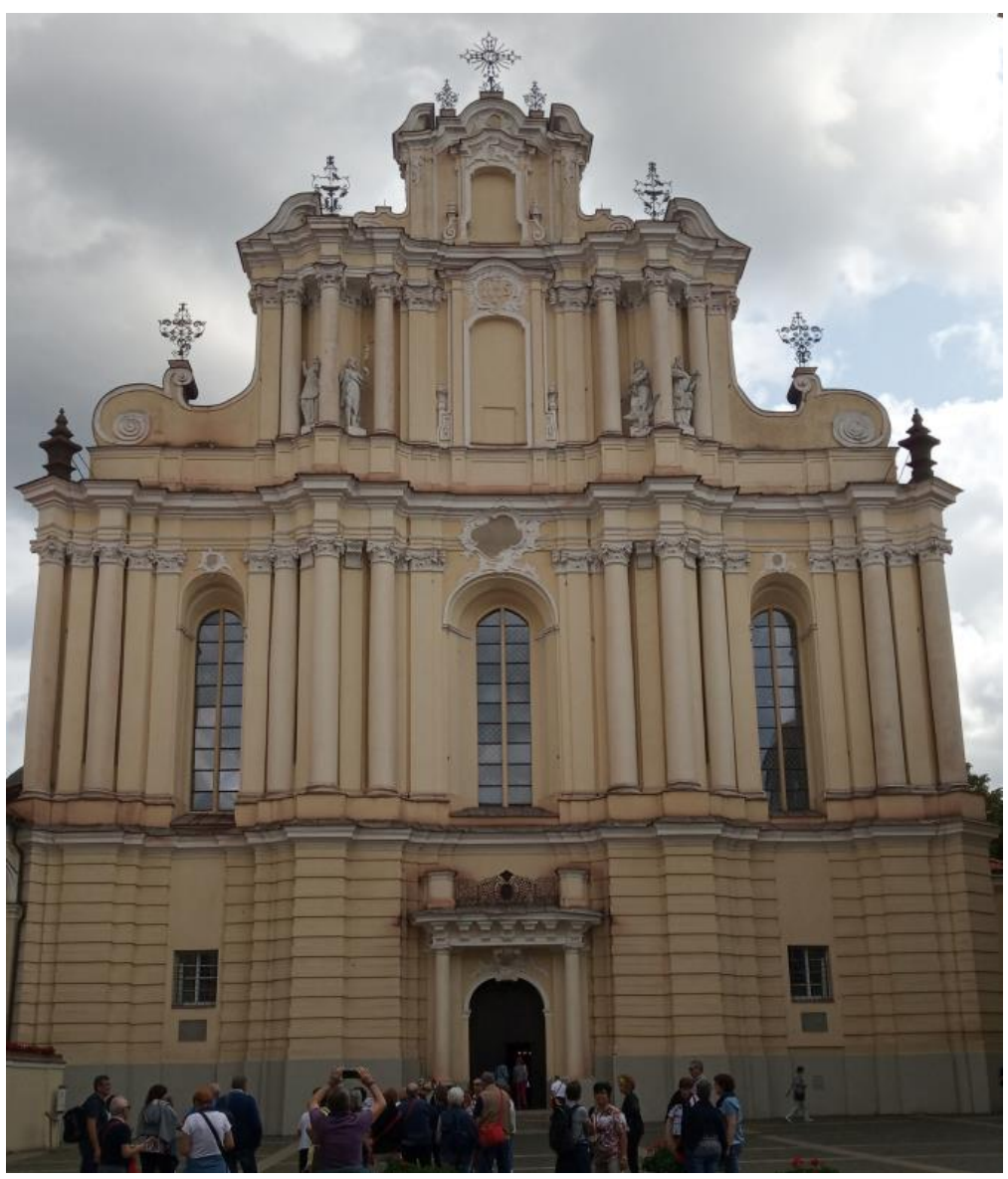

(a)

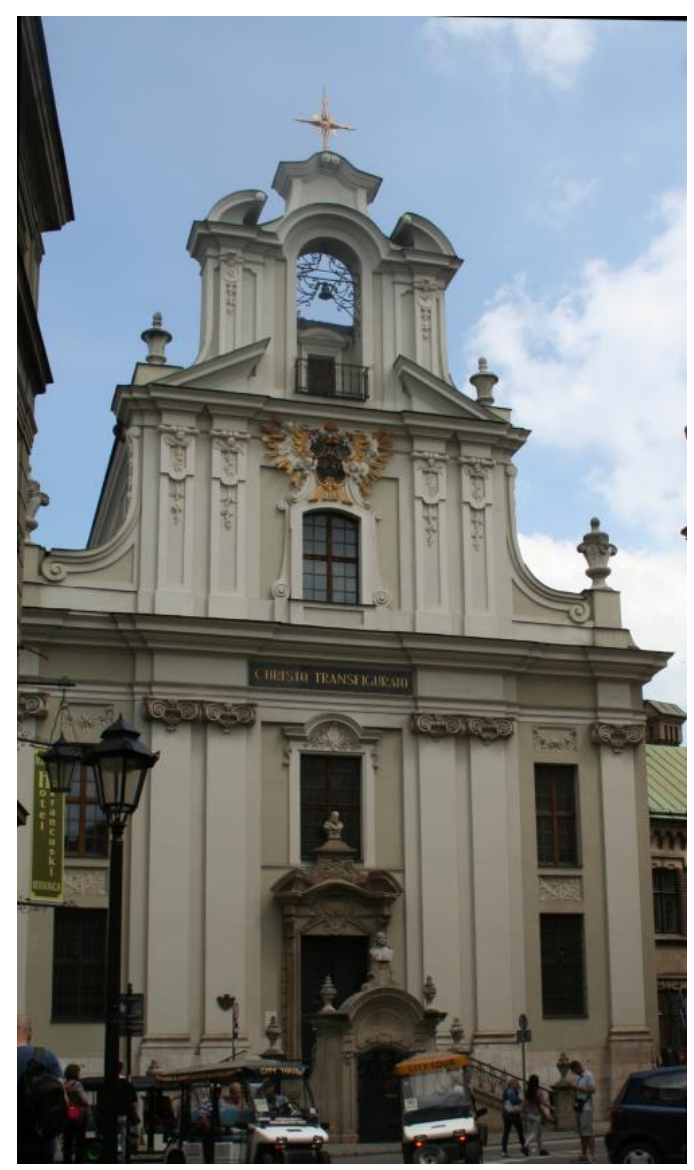

(b)

Figure 19. The late Baroque examples of highlighting the vertical articulation of the architectural structure with color: (a) the façade of the church of St. John the Baptist and St. John the Evangelist in Vilnius designed by J.K. Glaubitz (1738-1749); (b) the façade of the Piarist Church of the Transfiguration of Our Lord in Cracow (1759-1761) by F. Placidi. Photos Bogna Ludwig.

Further examples of such a system of polychrome façade order can be found among the continuations and imitations of South German and Czech models, such as the façades of the Church of the Purification of the Blessed Virgin Mary in Dub nad Moravou (1756), the Minorite Church of St Anthony in Eger (1758-1773), (recently repainted from red to ochre in 2013), and the works of the next generation of artists from the Como region working in Italy, such as Andrea Nono, author of the Rococo façades of the Church of the Holy Trinity in Crema (1740). Tuscan Bartolomeo Rastrelli, working in Ukraine and Russia, designed the façades of St Andrew's Cathedral in Kiev (1747 and 1754), the Smolny Monastery in St Petersburg (1748-1764) and the Winter Palace (1754-1762) in the same color scheme. 


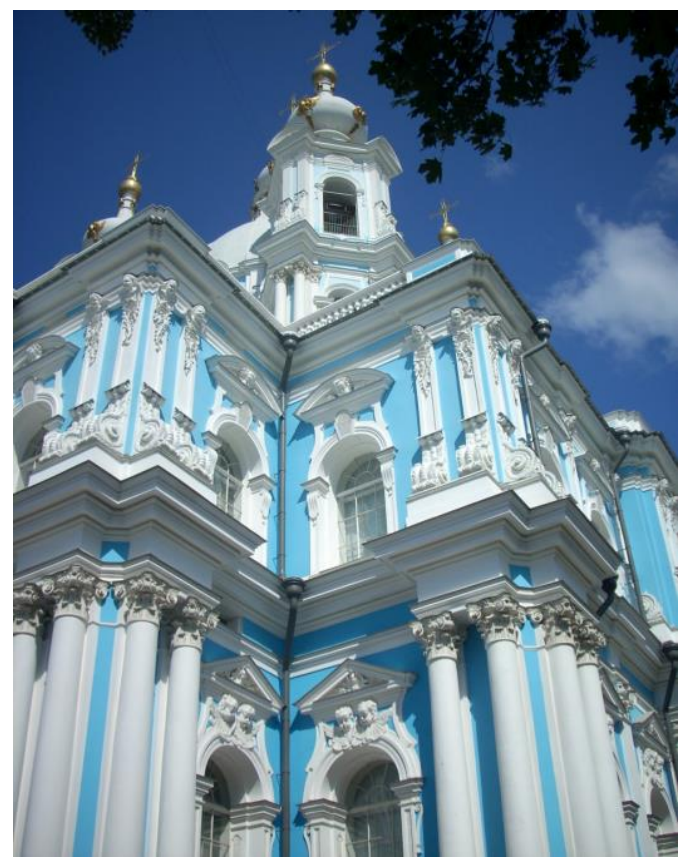

Figure 20. Despite the ahistorical color of the walls, the polychromatic distinction of the vertical structure was preserved. The Smolny Cathedral in St. Petersburg, Russia (1748-1764) designed by Bartolomeo Rastrelli. Photo Marta Galantowicz.

\section{Discussion. The role of color arrangement of the components of architectural order in shaping compositional expression}

During the early Renaissance, architectural detail introduced into the façades became a linear element defining compositional divisions. The most important task was to guarantee its legibility, which could be achieved by contrasting order structures against the background of walls. The simplest method was the bicolor juxtaposition of profiles and the façade face, which differed significantly in shade or color. Bichromatic contrasting of grey or red entablature and supports against a pale wall was the most common solution. The earliest examples of the use of antique-inspired arrangements of entablature show the treatment of the frieze area as the surface of the wall, which emphasized the role of horizontal divisions in the structure of the façade decoration. A more thorough knowledge of antique architecture and distinction of principles binding in designing specific architectural orders resulted in introduction of much richer, multi-element profiles, ornamentally decorated, varied with dentil bands and consoles under the cornice as well as cymatia and astragals. The forms and ornaments could be highlighted by means of polychrome, as it was done in antiquity. Gilding and then polychroming of architectural decorations started and was mainly applied in case of stuccowork in interiors. It served the purpose of emphasizing small details and highlighting decorativeness. Thus, it made it possible to bring out the linear drawing in the elaboration of the elements of the order system. Colored backgrounds and moldings were a specific continuation of the medieval interest in details, which was revealed in the paintings of the Italian quattrocento or the art of the early Dutch Renaissance. Even with very rich color versions, used mainly in interiors, with marquetry and marbling or multicolored polychromes, the color decoration of architectural orders was left with these two tasks - compositional influence, emphasizing the horizontality of the layout and precise linearity, characteristic features of the Renaissance.

Initially, the same compositional values were sought to be emphasized on monochromatic façades. During the mature Renaissance, the focus was on reproducing classical designs as closely as possible in balanced architectural structures. Mannerist architects, largely limiting themselves to completely monochromatic façades or an architectural order maintained in one color against a different wall background, tried to emphasize the expression of form through nuances of chiaroscuro, tonal effects rather than col- 
or. These measures were analogous to those used in the sculpture of the period, and partly also in the painting of Tenebrism. Significant for the architectural solutions adopted was the background of architects who simultaneously worked as sculptors or painters, such as Michelangelo, Bernini or Pietro da Cortona (Payne 2014). The ability to operate with such sophisticated effects was also determined by excellent knowledge of the material. One can cite the example of Borromini, who worked as a stonemason in his youth. At the same time, the influences of his work as a stucco artist were also important and, in particular, were widely reflected in his work (Blunt 1979).

In spite of the creation of various artistic effects of the façades, sometimes extremely dynamic, both in the Mannerist and early Baroque periods, the basic principle was to maintain or even emphasize the continuity of the elements of the entablature. This was also important when introducing bichromatic or polychromatic solutions within the architectural order structures on the façades. The special role that the inscription frieze gained in the iconographic program of the façades of sacral buildings (but also in their interiors) and the heritage of the Renaissance experience in its decoration influenced the decision to emphasize this field with a different color. Even more frequently, material savings limiting the use of stone to the elements of cornices and architraves determined the decision to make the frieze in brick and plaster. The chromatic solutions of the façades followed two basic courses: continuation of the tonally or color-contrasted two-color scheme, or enrichment of the scale of chiaroscuro effects by subtle color differentiation of the walls and friezes with decorative details. The continuity of horizontal stone and later stucco elements created clear belt arrangements on the façades. In the Mannerist period, simultaneous introduction of accented, especially large-order, vertical components of structures in the form of supports, most frequently pilasters, in front of the wall face, resulted in the typical for that period double character of artistic expression. In the Baroque, the vertical direction of the composition was strongly emphasized by multiplying or applying perspective arrangements of supports, and finally by embattling cornices. However, in the system of façade tectonics, the moment of stopping the upward flight of the eyes in the form of horizontal massive strips of crowning entablature remained. This weakened the dynamics of the structure, but emphasized its monumentality. A change was brought about only by decisions regarding the material and color separation of elements of the frieze above the supports within the embattled entablature, the type of imposts above the chapiters of semi-columns or, more frequently, pilasters. The uniform color of all vertical elements of the façade structure, sometimes interrupted only by a small, very decorative fragment of differently treated capitals, guaranteed an unambiguous verticality of the composition. It is characteristic that from the very beginning, the introduction of successive stages of this solution, from molding of the cornice to color separation of the pseudo-imposts, was connected with the influence of the medieval tradition, e.g. with the designs of the Milan Cathedral façade, or with the introduction of the concept of post-Reformation church façade in the countries where until then the Gothic forms dominated in architecture. It also depended on the personal inspiration of the designers with strongly expressive Gothic structures, as in the case of the artists of the mature and late Baroque of Central Europe. These decisions on the disposition of colors within the entablature in the architectural order had a particularly significant influence on the final expression of the work.

In most cases, the question of whether the color solution was developed by the architect or one of the contractors remains unresolved. However, even if it was the choice of one of the executors, in the case of Baroque buildings he repeatedly demonstrated a thorough understanding of the architectural expression of the façade structures. It is interesting that this applies not only to the works of the most eminent artists, but also to more modest buildings from more provincial areas. Perhaps this was due to a very conscious copying of patterns and an understanding of the artistic intent of the designers.

\section{Conclusions. Significance of conservators' decisions in the field of coloring and shaping the compositional effect of Baroque architecture}


It is also uncertain whether all solutions of color schemes originate from the times when the buildings were constructed or resulted from careful stratigraphic research conducted by conservators. Some polychromes may have been lost permanently; sometimes the later layers are wrongly interpreted as the original ones, which is reflected in decisions on radical changes of the architectural color scheme restored after the latest research. In recent times great emphasis was put on correct identification of original polychrome. It seems, however, that in some cases it is limited to determining the colors and pigments used, and not their exact distribution on all fragments of the façade. Often the upper parts of the building are heavily damaged, which makes it difficult to decipher correctly the coloring of the entablature, and in particular to resolve the issue of the color split of the frieze field.

As it can be seen from the presented considerations, and what we mostly realize (Philippot [1988] 1998), the meaning of the impact of an architectural work in the surrounding space is significantly influenced by the choice of color. However not everyone is probably aware how important for the expression of baroque façades is the decision concerning the color continuity of the frieze or the introduction of pseudo-imposts distinguished in color above the supports of the architectural order. This can be illustrated by examples, where the vertical ordering of the architectural structure is changed to an arrangement with an accentuated entablature by the uniform color of the frieze (e.g. on the façade of the parish church of St. Nicholas and St. Francis Xavier in Otmuchów), or without the possibility of research, in the case of reconstructed buildings it is decided to introduce a pattern with colorful imposts (the Jesuit church in Warsaw, where in 2008 a polychrome arrangement was designed, referring to analogous color solutions, probably without realizing that it would be one of the earliest examples of this solution).

Of course it is inevitable that design decisions concerning the restoration of the color scheme of baroque façades are based on conservation research, which cannot answer all the questions due to its limited possibilities. It is necessary to use general knowledge, information drawn from analogous projects, or those created in a similar circle of artists, place or time. Perhaps this article will be a contribution to such considerations in the field of solving the color scheme of architectural order structures.

Funding: This research received no external funding.

Acknowledgments: Photos Fig. 1a and 20 author Marta Galantowicz, Fig. 2a Katarzyna Ludwig and $4 b, 5 b, 6,7$ and 15 Sebastian Wróblewski.

Conflicts of Interest: The authors declare no conflict of interest.

\section{Appendix A}

A 1 Briano duplicated the pattern of embattled entablature from the Northern Italian solution, also used in church in Palermo, in the construction of which he participated. However, perhaps due to material shortages, he ordered only reinforcements in the frieze part over the supports of stone.

\section{References}

1. (Abbate 2001) Abbate, Francesco. 2001. Storia dell'arte nell'Italia meridionale. Roma: Donizelli, vol. 3 , s.329

2. (Acanto Restauri 2020a) Acanto Restauri. 2020a. Chiesa di Santa Maria della Vittoria (Roma) 2011. Interventi, https://www.acantorestauri.it/portfolio/chiesa-di-santa-maria-della-vittoria-roma/

3. (Acanto Restauri 2020b) Acanto Restauri. 2020b. Basilica di Sant'Andrea della Valle (Roma). Interventi, https://www.acantorestauri.it/portfolio/basilica-di-santandrea-della-valle-roma/

4. (Acanto Restauri 2020c) Acanto Restauri. 2020c. Chiesa di Sant'Ivo alla Sapienza (Roma) 2012. Interventi, https://www.acantorestauri.it/portfolio/chiesa-di-santivo-alla-sapienza-roma/

5. (Acker 1972) van Acker, Jules. 1972. Belgique baroque et classique, 1600-1789, Bruxelles: Marc Vokaer, pp.12-14.

6. (Alberti [1485] 1541) Alberti, Leon Battista. 1541. De Re aedificatoria libri decem Leonis Baptistae Alberti. Edited by J. Cammerlander (Argentorati). Strasbourg: Eberhard Tappe. First published 1541. https://gallica.bnf.fr/ark:/12148/bpt6k857506k/f68. 
7. (Alberti [1485] 1565) Alberti, Leon Battista. 1565. L'architettura di Leon Batista Alberti. Tradotta in lingua Fiorentina da Coì̀mo Bartoli Gentil Huomo e Accademico Fiorentino. Nel Monte Regale [Mondovi]: Lionardo Torrentino, https://archive.org/details/larchitettura00albe/page/188/mode/2up

8. (Ałykow 2014) Ałykow, Zespół Inżynierów 2014? Opactwo Cystersów w Krzeszowie - kościół p.w. Wniebowzięcia Najświętszej Maryi Panny, Bazylika Mniejsza (XVIII w.) https://alykow.com/opactwo-cystersow-w-krzeszowie.html

9. (Angelo 2018) Angelo, Tommaso. 2018. I rinforzi per il consolidamento e miglioramento sismico della chiesa di san Barnaba a Modena. Ingenio

$09 / 02$,

https://www.ingenio-web.it/18924-i-rinforzi-per-il-consolidamento-e-miglioramento-sismico-della-chiesa-di-san-barnaba-a-m odena

10. (Antista 2009) Antista, Giuseppe. 2009. Il libeccio antico. Un marmo del barocco siciliano. Lexicon. Storie e architettura in Sicilia e nel Mediterraneo. Rivista semestrale di Storia dell'Architettura. file://C:/Users/Z30/AppData/Local/Temp/Dialnet-IlLibeccioAntico-5775400.pdf

11. (Argan 1955) Argan, Giulio Carlo. 1955. Borromini. Verona: Mondadori, p. 107. http://www.mindeguia.com/tesis/LT_10-abstracta2.pdf

12. (Balestreri 2017) Balestreri, Isabella. 2017. Francesco Maria Ricchino (1584-1658), progetti milanesi fra storia e storiografia. Studi e Ricerche 1: 28-47, http://www.edizionicaracol.it/wordpress/wp-content/uploads/2016/06/2 Balestriri-pag-singola.pdf

13. (Bauer 2020) Bauer, Markus. 2020. Die Restaurierung des Schönhof. In Moderne Kultureinrichtungen im Denkmal - Chancen und Grenzen. Görlitz: Stiftung Schlesisches Museum zu Görlitz, pp. 33-37 https://www.schlesisches-museum.de/fileadmin/user_upload/slider/ueber_uns/projekte/tagung_sband_denkmal_druckversio $\underline{\text { n.pdf }}$

14. (Bellini 2011) Bellini, Federico. 2011. La basilica di San Pietro: da Michelangelo a Della Porta. Rome: Argos, pp. $169,417$.

15. (Benedetti 2012) Benedetti, Simona. 2012. La molteplice poetica di Carlo Rainaldi: progetti, modelli, architetture. In: Architetture di Carlo Rainaldi: nel quarto centenario della nascita. Edited by Simona Benedetti, Roma: Gangemi, pp. 242-253 (203-253)

16. (Bernstock 1988) Bernstock, Judith. 1988. Bernini's tomb of Alexander VII. Saggi e Memorie di storia dell'arte 16: 167-190, 363-373, https://www.jstor.org/stable/43140589?seq=9\#metadata info tab contents

17. (Bertram 1961) Bertram, Walther. 1961. Die Restaurierung der Giebelfassade von St. Michael in München. Deutsche Kunst und Denkmalpflege 1: 35-38, p. 36

18. (Betlej 2000a) Betlej, Andrzej. 2000a. Kościół Jezuitów w Krzemieńcu. Uwagi na temat autorstwa i genezy architektury oraz relacji architekt-fundator. In Studia nad sztuka renesansu i baroku. Edited by Jerzy Lileyko, vol. 5, pp. $193-216$. http://archiv.ub.uni-heidelberg.de/artdok/3424/1/Betlej_Kosciol_jezuitow_w_Krzemiencu_2000.pdf

19. (Betlej 2000b) Betlej, Andrzej. 2000b. Uwagi na temat twórczości architektonicznej Pawła Giżyckiego. Zarys katalogu dzieł. In Sztuka ziem wschodnich Rzeczypospolitej XVI - XVIII w. Edited by Jerzy Lileyko. Lublin: Towarzystwo Naukowe Katolickiego Uniwersytetu Lubelskiego, pp. 495-514 https://d-nb.info/1211355497/34

20. (Betlej 2002) Betlej, Andrzej. 2002. „Lwowskie” projekty Giacoma Briana a fasada krakowskiego kościoła świętych Piotra i Pawła. In Magistro et Amico amici discipulique. Lechowi Kalinowskiemu w osiemdziesięciolecie urodzin. Edited by Jerzy Gadomski, Adam Małkiewicz, Anna Różycka Bryzek and Klementyna Żurowska. Kraków: Wydawn. Uniwersytetu Jagiellońskiego, pp. 271-281, http://archiv.ub.uni-heidelberg.de/artdok/4924/1/Betlej_Lwowskie_projekty_Giacoma_Briana_2002.pdf

21. (Betlej 2003) Betlej, Andrzej. 2003. Pawet Giżycki SJ architekt polski XVIII wieku. Kraków: Towarzystwo Naukowe "Societas Vistulana", pp. 152-153

22. (Betlej 2018) Betlej, Andrzej. 2018. Architecture of Jesuit Churches in the Former Polish-Lithuanian Commonwealth, 1564-1773. Journal of Jesuit Studies 5, Issue 3: 352-384 https://brill.com/view/journals/jis/5/3/article-p352 352.xml?language=en

23. (Białobłocka 2014) Białobłocka, Karolina. 2014. Historic colour schemes in silesian secular interiors. Technical Transactions, Architecture 10-A: 3-18 file:///C:/Users/Z30/AppData/Local/Temp/Architektura-Zeszyt-10-A-(23)-2014-1.pdf

24. (Bieri [2008] 2012) Bieri, Pius. 2008, rev. 2012. Br. Heinrich Mayer SJ (1636-1692) In Süddeutscher Barock https://www.sueddeutscher-barock.ch/In-Meister/h-r/Mayer Heinrich.html

25. (Bieri 2017) Bieri, Pius. 2017. Carlo Lurago (1615-1684). In Süddeutscher Barock https://www.sueddeutscher-barock.ch/In-Meister/h-r/Lurago Carlo.html

26. (Blunt 1956) Blunt, Anthony. 1956. Le Concile de Trente. In Anthony Blunt, Le teorie des arts en Italie de 1450-1600, Paris: Gallimard, pp. 175-219.

27. (Blunt 1979) Blunt, Anthony. 1979. Borromini. Cambridge-London: Belknap, Harvard University Press, pp. $24,68$.

28. (Borromeo 1572) Borromeo, Carlo. 1572. Instuctiones Fabricae et Supellectilis Ecclesiasticae, Romae, Fondazione Memofonte onlus Studio per l'elaborazione informatica delle fonti storico-artistiche https://www.memofonte.it/home/files/pdf/scritti borromeo.pdf (10.12.20)

29. (Brzezowski 2000) Brzezowski, Wojciech. 2000. Faktura i kolorystyka elewacji barokowych na Śląsku. Architectus 1 (7): 61-70;

30. (Brzezowski 2010) Brzezowski, Wojciech. 2010. Kolorystyka architektoniczna na Śląsku w XVII i XVIII w. In Kolorystyka zabytkowych elewacji od średniowiecza do współczesności. Historia i konserwacja. Materiały międzynarodowej konferencji z okazji 30-lecia wpisu Starego Miasta w Warszawie na Listę Światowego Dziedzictwa UNESCO. Warszawa 22-24 września 2010. Edited by Karol Guttmejer. Warszawa: Krajowy Ośrodek Badań i Dokumentacji Zabytków, pp. 113-123.

31. (Brzezowski and Wanat 2002) Brzezowski Wojciech, and Piotr Wanat. 2002. Barokowe elewacje klasztorów w Henrykowie i Kamieńcu Ząbkowickim. Architectus 1 (11): 91-104, http://architectus.pwr.edu.pl/files/numery/arch 2002 1.pdf 
32. (Bugini and Folli 2005) Bugini, Roberto and Luisa Folli. 2005. Le pietre impiegate nell'architettura milanese e lombarda. In Lezioni di petrografia applicata. Milano: CNR Istituto per la Conservazione e la Valorizzazione dei Beni Culturali, no pages, http://www.naturalstoneinfo.com/download/pietre.mi.pdf

33. (Bulfone Gransinigh and Amendolagine 2017) Bulfone Gransinigh, Federico and Francesco Amendolagine. 2017. Il cantiere della calce fra continuita' e rinnovamento, Actas del Décimo Congreso Nacional y Segundo Congreso Internacional Hispanoamericano de Historia de la Construcción. Donostia-San Sebastián, 3-7 octubre 2017. Madrid: Instituto Juan de Herrera. Actas 1: 225-234.

34. (Camerota 2001) Camerota, Filippo. 2001. Architettura dipinta. In Nel segno di Masaccio: l'invenzione della prospettiva. Edited by Filippo Camerota. Firenze: Istituto e Museo di Sienze, p. 148.

35. (Campisi 1986) Campisi, Michele. 1986. I colori del Palazzo Senatorio in Roma nei Conti della Camera Capitolina. Bollettino d'Arte. Intonaci colore e coloriture nell'edilizia storica. Atti del Convegno di Studi, Roma 1984, vol. I, Supplemen to 35-36: 87-89 http://www.bollettinodarte.beniculturali.it/opencms/multimedia/BollettinoArteIt/documents/1372165151842_20_-_M._Campis i.pdf

36. (Carlen 1981) Carlen, Georg. 1981. Zur Fassadenrestaurierung der Solothurner Jesuitenkirche. Bericht der Denkmalpflege, Unsere Kunstdenkmäler: Mitteilungsblatt für die Mitglieder der Gesellschaft für Schweizerische Kunstgeschichte 32 Issue 1: 84-92 http://docplayer.org/76526617-Zur-fassadenrestaurierung-der-solothurner-jesuitenkirche-bericht-der-denkmalpflege.html

37. (Castelli Gattinara 2015) Castelli Gattinara, Federico. 2015. Il color travertino dei Santi Luca e Martina. Il Giornale dell'Arte. 1 dicembre https://www.ilgiornaledellarte.com/articoli/2015/12/125351

38. (Catalogo 2005-2007) Catalogo della Collezione di Marmi Antichi, 2005-2007. Il Museo di Storia Naturale dell'Accademia dei Fisiocritici, Accademia dei Fisiocritici Onlus http://www.musnaf.unisi.it/risultatomarmi.asp

39. (Conforti et al. 2020) Conforti, Claudia, Fabio Colonnese, Maria Grazia D'Amelio and Lorenzo Grieco. The Critical Agency of Full-Size Models, from Michelangelo and Bernini to the Picturesque Garden. Architectural Theory Review Volume 24 Issue 3: 307-326 https://www.tandfonline.com/doi/full/10.1080/13264826.2021.1925716?src= ;

40. (DecArch 2014) DecArch. 2014. barocca: avevate mai visto un kyma ionico con le facce? (S.Ivo alla Sapienza) https://twitter.com/DecArchit/status/529171571580358656

41. (Desogus 2006) Desogus, Restauri, $2006 . \quad$ Santa Novella, https://www.desogusrestauri.it/restauri/santa-maria-novella-firenze/.

42. (Dettloff 2010) Dettloff, Paweł, 2010. Kolorystyka barokowych fasad kościelnych Krakowa. Zarys problematyki. In Kolorystyka zabytkowych elewacji od średniowiecza do współczesności. Historia i konserwacja. Materiały międzynarodowej konferencji z okazji 30-lecia wpisu Starego Miasta w Warszawie na Listę Światowego Dziedzictwa UNESCO. Warszawa 22-24 września 2010. Edited by Karol Guttmejer. Warszawa: Krajowy Ośrodek Badań i Dokumentacji Zabytków, pp. 125-145.

43. (Di Mauro 2020) Di Mauro, Leonardo. 2020. Anonimo Palazzo Farnese in costruzione 1541 ca. Catalogo delle opere della parte seconda. In Leonardo e il Rinascimento nei Codici napoletani: Influenze e modelli per l'archittetura e l'ingegnieria. Edited by Alfredo Buccaro, Maria Rascaglia, Napoli: Cirice, pp. 637-640.

44. (Dzieciątkowska 2010) Dzieciątkowska, Justyna. 2010-2011. Sanktuarium Matki Bożej w Świętej Lipce. Konserwacja fasady. Projekty MAPEI 4465 https://www.mapei.com/pl/pl/projekty/szczegoly-projektu/sanctuary-of-st-mary--wi-ta-lipka-4990

45. (Ecker 2003) Ecker, Wolfgang, Gesellschaft 2003. Pfarrkirche Laxenburg. Denkmalpflege, https://www.ecker-stein.at/referenzen/denkmalpflege/pfarrkirche-laxenburg

46. (Ecker 2003) Ecker, Wolfgang, Gesellschaft 2003. Pfarrkirche https://www.ecker-stein.at/referenzen/denkmalpflege/pfarrkirche-mariahilf

47. (Ecker 2010) Ecker, Wolfgang, Gesellschaft 2010? Dominikanerkirche (Wien Innere Stadt). Denkmalpflege Archiv, https://www.ecker-stein.at/referenzen/denkmalpflege-archiv/dominikanerkirche-st-maria-rotunda

48. (Ecker 2013) Ecker, Wolfgang, Gesellschaft 2013. Stift Klosterneuburg - Stiftsgebäude Außenfassaden (Restaurierung 2010-2013). Denkmalpflege, https://www.ecker-stein.at/referenzen/denkmalpflege/fassade-stift-klosterneuburg

49. (Elam 2017) Elam, Caroline. 2017. Giuliano da Sangallo, Florence. Exhibitions. The Burlington Magazine November: 937-939

50. (Ertl 2019) Ertl, Florian. 2019. Jesuitenkirche Sankt Michael wird renoviert. Citykirche in München 02.04. https://mk-online.de/meldung/jesuitenkirche-sankt-michael-wird-renoviert.html

51. (Eures Arte 2013) EURES ARTE. 2013. Chiesa dei SS. Biagio e Carlo ai Catinari (Roma). In Stucchi (monocromi, policromi, dorati) e dipinti murali http://www.euresarte.it/project/stucchi/

52. (Fano 1979) Fano, Gaetano. 1979. Correzioni ed illusioni ottiche in architettura. Bari: Laterza, pp. 62-63.

53. (Fant et al. 2019) Fant, Rebecca, Cristina Miedico and Folco Vaglienti. 2019. La pietra di Angera. Uso storico, economico e problemi di conservazione. In Le vie della pietra. Estrazione e diffusione delle pietre da opera alpine dall'età romana all'età moderna. Atti del Convegno in occasione del decennale dell'Ecomuseo del Granito di Montorfano. Edsited by Gruppo Archeologico e Museo di Mergozzo. Mergozzo: Ecomuseo del Granito di Montorfano, pp. 137-164, https://www.academia.edu/44477870/La pietra_di_Angera_Uso_storico_economico e problemi_di_conservazione.

54. (Ferretti 2020) Ferretti, Emanuela. 2020. All'ombra di Leon Battista Alberti e Michelangelo: modelli lignei e cultura architettonica fra Cosimo Bartoli, Vincenzo Borghini e Giorgio Vasari. Kritikè 1: 83-114.

55. (Fratini et al. 2014) Fratini, Fabio, Elena Pecchioni, Emma Cantisani, S. Rescic, and Silvia Vettori. 2014. Pietra Serena: The stone of the Renaissance. Geological Society, London, Special Publications 407 Issue 1: 173-186.

56. (Frommel 1995) Frommel, Christoph L. 1995. 11 Palazzo Senatorio. In La facciata del Palazzo Senatorio in Campidoglio: momenti di un grande restauro a Roma. Edited by Maria Elisa Tittoni. Ospedaletto: Pacini, pp. 31-45, http://archiv.ub.uni-heidelberg.de/artdok/7196/1/Frommel Il Palazzo Senatorio_1995.pdf. 
57. (Funiciello and Mattei 1991) Funiciello, Renato and Massimo Mattei. 1991. Le rocce di faglia nel Barocco Romano. Le Scienze 276: 38-45, http://download.kataweb.it/mediaweb/pdf/espresso/scienze/1991_276_4.pdf

58. (García 2019) García, Jorge Tomás. 2019. Classical Tradition and the Painting of Giovanni da Udine, RES Antiquitatis 1: 14-28, https://research.unl.pt/ws/portalfiles/portal/17646351/Classical Tradition and the Painting of Giovanni da Udine.pdf.

59. (Gasparini and Pensabene 2017) Gasparini, Eleonora and Patrizio Pensabene. 2017. Il "marmo di Cottanello". In La Villa Romanadi Cottanello. Edited by Patrizio Pensabene and Carla Sfameni, Bari: Edipuglia, pp. 315-330, https://www.academia.edu/41250692/Il marmo di_Cottanello

60. (Grodzicka 1960) Grodzicka, Maria. 1960. Kilka uwag o polichromii wawelskich portali z epoki zygmuntowskiej. Studia do Dziejów Wawelu 2: 449-450

61. (Grognardi and Tagliasacchi 1988) Grognardi, Daniela and Germano Tagliasacchi. 1988. In Colore in un ambiente barocco. Tinte e Attrezzature Urbane di Via e Piazza Palazzo di Città a Torino (1600-1900). Torino: Allemandi.

62. (Gunzelmann 2016) Gunzelmann, Thomas. 2016. Steinlandschaften - wo die Bamberger Bausteine herkommen. In Naturstein nachhaltiger Umgang mit einer wertvollen Ressource. Dokumentation des Expertenworkshops "Schöne Steine aus der Heimat?! Nachhaltiger Naturwerksteinersatz: sozial, ökonomisch, ökologisch" am 13. und 14. Januar 2015 in Bamberg. Edited by Inge Gotzmann. Frankfurt Leipzig BHU, pp. https://www.thomas-gunzelmann.net/wordpress/wp-content/uploads/2016/02/08-Gunzelmann.pdf

63. (Guttmejer 2019) Guttmejer, Karol. 2019. Kościół Trynitarzy w Wilnie. Uwagi o jego budowaniu. Acta Universitatis Nicolai Copernici, Zabytkoznawstwo i Konserwatorstwo 50: 7-48.

64. (Hauck 2011) Hauck, Michael. 2011. Die Fassaden am Dom St. Stephan in Passau. Die Erneuerung der barocken Kalkfassung als Teil eines konservatorischen Gesamtkonzepts, In Kalk in der Denkmalpflege. Bindemittel in der Restaurierung. Erfahrungsberichte aus der Praxis. Tagungsband; Inhalte, Projekte, Dokumentationen, Schriftenreihe des Bayerischen Landesamtes für Denkmalpflege. München: Volk Verlag, pp. 51-57

65. (Hemsoll 2016) Hemsoll, David. 2016. Palladio's Architectural Orders: From Practice to Theory, Published online by Cambridge University Press: 12 January, palladios_architectural_orders_from_practice_to_theory.pdf, https://www.cambridge.org/core/services/aop-cambridge-core/content/view/C68A90DF5BA41B45C0899B72CDAB3284/S0066 622X00002574a.pdf/palladios_architectural_orders_from_practice_to_theory.pdf

66. (Hills 1999) Hills, Paul. 1999. Polychromy in Early 15th Century Venetian Architecture and Sculpture. In Paul Hills, Venetian Colour: Marble, Mosaic, Painting and Glass 1250-1550, 1999, New Haven: Yale University Press, pp. 57-90, https://www.academia.edu/42989793/Polychromy_in_Early_15th_Century_Venetian_Architecture_and_Sculpture

67. (Iton 2018) ITON S.r.l. (Interventi speciali per l'edilizia). 2018. Ripristino, miglioramento sismico della Chiesa di San Barnaba Modena, https://iton.it/ripristino-miglioramento-sismico-della-chiesa-san-barnaba-modena/

68. (Jaskanis 2011) Jaskanis, Paweł. 2011. Kolory baroku w wilanowskim pałacu Silva Rerum -04-27, https://www.wilanow-palac.pl/kolory baroku w wilanowskim palacu.html

69. (Karpowicz 2011) Karpowicz, Mariusz. 2011. Wileńska odmiana architektury XVIII wieku. Biuletyn Historii 73 Issue 3-4: 371-414,

70. (Katalog zabytków 1993) Kościół Matki Bożej Łaskawej. Katalog zabytków sztuki w Polsce. Miasto Warszawa, t. XI, cz. 1, red. J. Z. Łoziński and A. Rottermund, Warszawa, s. 223-228

71. (Knoepfli 1965) Knoepfli, Albert. 1965. Stuck-Auftrag und Stuck-Polychromie in der barocken Baukunst. In: Festschrift Hans Burkard, Restauration und Renovation im Kirchenbau. Edited by Hans Burkard. Gossau: Cavelti \& Co., pp. 37-82.

72. (Koberová 2017) Koberová, Veronika. 2017. Reconstruction of front façade of Loreto from the heritage preservation perspective. In Dientzenhofers and Loreto. Exhibition catalogue. Edited by Peter Bašta and Markéta Baštová. Praha: Provincie kapucínů v ČR, pp. 41-62, https://issuu.com/loreto-prague/docs/dientzenhofer cz issuu

73. (Koller 1979) Koller, Manfred. 1979. Die Farbigkeit der Stukkatur - zu ihrer Entwicklungsgeschichte in Österreich vom 16. bis 18. Jahrhundert. Kunstjahrbuch der Stadt Linz, 1979: 5-29.

74. (Koller 1997) Koller, Manfred. 1997. Die Fassaden der Wiener Hofburg. Erforschung und Restaurierung 1987-1997. Österreichische Zeitschrift für Kunst und Denkmulpflege 51: 494-536.

75. (Koller 1998) Koller, Manfred. 1998. Zur Farbigkeit der Salzburger Bauten Johann Bernhard Fischers von Erlach. Barockberichte 18/19:

$77-87$,

https://www.salzburgmuseum.at/fileadmin/Salzburg_Museum/06_Service/Publikationen/03_Barockberichte/Pdfs_Barockberi chte/BB_18_19/Koller_Farbigkeit.pdf

76. (Koller 2003a) Koller, Manfred. 2003a. Material und Farbe in der Architekturoberfläche - Begriffe und Bedeutung, In Historische Architekturoberflächen: Kalk, Putz, Farbe. Internationale Fachtagung des Deutschen Nationalkomitees von ICOMOS und des Bayerischen Landesamtes für Denkmalpflege, München, 20.-22. November 2002. Historical architectural surfaces: lime, plaster, colour. Edited by Jürgen Pursche. München: Lipp, p. 114-119, file://C:/Users/Z30/Downloads/20980-Artikeltext-54792-1-10-20150611.pdf.

77. (Koller 2003b) Koller, Manfred. 2003c. „Steinfarbe“ und "Ziegelfarbe“ in der Skulptur und Architektur vom 13. bis 19. Jahrhundert. Restauro 2: 123-129.

78. (Koller 2003c) „Schönbrunner Gelb“ - Kaiserlicher Trend mit Zukunft. 2003c. (Interview with Manfred Koller). Baumit Journal 2/2003: 5, https://en.calameo.com/read/001102318ce6a6bc54c79

79. (Koller 2007) Koller, Manfred. 2007. Sehen und Verstehen - Architektur und Farbe. Denkmalpflege in Niederösterreich 55: 6-11 https://www.noel.gv.at/noe/Kunst-Kultur/Denkmal Band 55.pdf 
80. (Koller 2010) Koller, Manfred. 2010 Untersuchungen und Restaurierungen an Fassaden Jakob Prandtauers. In: Jakob Prandtauer (1660-1726). Planen und Bauen im Dienst der Kirche. Katalogbuch zur Sonderausstellung des Diözesanmuseums St. Pölten aus Anlass des 350. Geburtstages Jakob Prandtauers8. Mai bis 30. Oktober 2010. Edited by Wolfgang Huber und Huberta Weigl St. Pölten: Gradwohl, pp. 91-101.

81. (Koller 2017) Koller, Manfred. 2017. Über Denkmalwerte und Farbe in Architektur und Bauskulptur. Österreichische Zeitschrift für Kunst und Denkmalpflege 71 Issue 2/3: 235-241 file:///C:/Users/Z30/Downloads/OEZKD 2017 Heft 2-3.pdf

82. (Koller and Paschinger 1980) Koller, Manfred and Hubert Paschinger. 1980. Die Fassadenfarbigkeit von Stift Melk. Österreichische Zeitschrift für Kunst und Denkmalpflege 34: 88-95.

83. (Koortbojian 1991) Koortbojian, Michael. 1991. Disegni for the Tomb of Alexander VII. Journal of the Warburg and Courtauld Institutes 54: pp. 268-273, https://www.jstor.org/stable/751499?seq=1\#metadata_info_tab_contents

84. (Kotrba 1976) Kotrba, Viktor. 1976. Česká barokní gotika. Dílo Jana Santiniho Aichla. Praha: Academia.

85. (Krasny 2017) Krasny, Piotr. 2017. Exempla viva. The prelates of the roman catholic church as inspirers of Charles Borromeo's instructions on shaping sacred art. Folia Historiae Artium, Seria Nowa 15: 35-58.

86. (Kummer 2010) Kummer, Stefan. 2010. Anfänge der neuzeitlichen Stuckdekoration in Rom. In Stuck des 17. und 18. Jahrhunderts. Geschichte-Technik-Erhaltung. Internationale Fachtagung des Deutschen Nationalkomitees von ICOMOS in Zusammenarbeit mit der Bayerischen Verwaltung der staatlichen Schlösser, Gärten und Seen. Würzburg, 4.-6. Dezember 2008. Edited by Jürgen Pursche. Berlin: Hendrik Bäßler, pp. 72-77, https://www.icomos.de/admin/ckeditor/plugins/alphamanager/uploads/pdf/Bd L Stuck.pdf.

87. (Kurzej [2012] 2018) Kurzej, Michał. 2018. Siedemnastowieczne sztukaterie w Małopolsce, Kraków: DodoEditor. First published 2012. https://issuu.com/dodoeditor/docs/siedemnastowieczne sztukaterie w ma

88. (Lazzarini 2012) Lazzarini, Lorenzo. 2012. Pietra d'Istria: quarries, characterisation, deterioration of the stone of Venice. In Materials from 12th International Congress on the Deterioration and Conservation of Stone, Columbia University, New York 2012, pp. 1-16, http://iscs.icomos.org/pdf-files/NewYorkConf/lazzarin.pdf

89. (Lenartowicz 2003) Lenartowicz, Światosław. 2003. Barokowy kościół Na Skałce, historia powstania i geneza formy. Peregrinus Cracoviensis 14: 143-162.

90. (Leone 2016) Leone, Stephanie. 2016. La costruzione di Palazzo Pamphilj. In Palazzo Pamphilj: Ambasciata del Brasilea Roma. Turin: Società Editrice Umberto Allemandi \& C. S.P.A., eScholarship@BC, Boston College University Libraries. pp. 15-67, https://dlib.bc.edu/islandora/object/bc-ir:107933/datastream/PDF/view

91. (Licciardello 2008/2009) Licciardello, Andrea. 2008/2009. I marmi policromi nell'architettura sacra del tardo cinquecento romano. Storia, conservazione e restauro. Doctoral thesis, Sapienza Università di Roma, Rome, Italy, pp. 49-58 file://C:/Users/Z30/AppData/Local/Temp/Tesi\%20dottorato\%20Licciardello.pdf

92. (Líčeníková 2017) Líčeníková, Michaela. 2017. Outline of construction development of the Prague Loreto. In Dientzenhofers and Loreto. Exhibition catalogue. Edited by Peter Bašta and Markéta Baštová. Praha: Provincie kapucínů v ČR, pp. 13-26.

93. (Mander 2005) Mander, Micaela 2005. Leoni. In Dizionario Biografico degli Italiani, vol. 64 Istituto della Enciclopedia Italiana fondata da Giovanni Treccani S.p.A. https://www.treccani.it/enciclopedia/leoni_(Dizionario-Biografico)/

94. (Marconi 1984) Marconi, Paolo. 1984. Colore e "colorito" in architettura: il cantiere storico, le tecniche storiche di manutenzione. Contributo al problema del "colore di Roma". Bollettino d'Arte. Il colore nell'edilizia storica. Riflessioni e ricerche sugli intonaci le coloriture. Supplement $\quad$ to 6: http://www.bollettinodarte.beniculturali.it/opencms/multimedia/BollettinoArteIt/documents/1371726293991_04_-_P._Marconi .pdf.

95. (Martinelli Braglia 1995) Martinelli Braglia, Graziella. 1995. Fassi, Guido. In Dizionario Biografico degli Italiani, vol. 45, Istituto della Enciclopedia Italiana fondata da Giovanni Treccani S.p. https://www.treccani.it/enciclopedia/guido-fassi (Dizionario-Biografico)/

96. (Moizi 2020) Moizi, Mirko. 2020. Tommaso Rodari e il Rinascimento comasco. Un'indagine sul cantiere del Duomo di Como tra XV e XVI secolo. Mendrisio: Accademia di architettura, Università della Svizzera italiana p. 51, 63, 193 https://doc.rero.ch/record/328783/files/Moizi_Tommaso_Rodari_e_il_Rinascimento_comasco.pdf

97. (Muratore 2010) Muratore, Oliva. 2010. Il colore dell'architettura storica: un tema di restauro. Firence: Alinea Editrice.

98. (Murczek 2017) Murczek, Manfred. 2017? Klaus Wedenig. Stiftskirche Melk, Wachau. Restaurierung Südturm der Westfassade. Alt bau neu. Objekte Niederösterreich https://www.altbauneu.at/objekte-nieder\%C3\%B6sterreich/stiftskirche-melk/

99. (Murray [1966] 1971) Murray, Peter. 1971. Architettura del Rinascimento. Venezia: Mondadori Electa, pp. 122-139. First published 1966.

100. (Olesiak 2017) Olesiak, Jacek. 2017. Technologie Remmers w renowacji architektury. Konserwacja kościoła pw. Świętych Apostołów Piotra i Pawła w Krakowie oraz Zamku w Pieskowej Skale. Renowacje $i$ Zabytki 3, no pages https://www.renowacjeizabytki.pl/artykuly-techniczne/Technologie-Remmers-w-renowacji-architektury.-Konserwacja-koscio la-pw.-Swietych-Apostolow-Piotra-i-Pawla-w-Krakowie-oraz-Zamku-w-Pieskowej-Skale,4631

101. (Palladio [1570] 1581) Palladio, Andrea. 1581. I quattro libri dell'architettura. Venice: Bartolomeo Carampello L. IV, Cap. VI, pp . 6-7, https://archive.org/details/iquattrolibridel01pall/mode/2up

102. (Paszenda [1998] 2015) Paszenda, Jerzy. 2015. Święta Lipka, Olsztyn: Ośrodek Badań Naukowych im. Wojciecha Kętrzyńskiego, pp. 16, 34

103. (Paszenda 1972) Paszenda, Jerzy. 1972. Briano, Giacomo. In Poplatek, Jan and Jerzy Paszenda. 1972. Słownik jezuitów artystów, Kraków; WAM, pp. 89-93

104. (Paszenda 1973) Paszenda, Jerzy. 1973. Biografia architekta Giacomo Briano, Biuletyn Historii Sztuki 35, Issue 1:10-18 
105. (Paszenda 1993) Paszenda, Jerzy. 1993. Architektura zespołu kościelnego w Świętej Lipce na tle polskiego baroku. Komunikaty Mazursko-Warmińskie 4:

511-518, https://bazhum.muzhp.pl/media/files/Komunikaty Mazursko Warminskie/Komunikaty Mazursko Warminskie-r1993-t-n4/ Komunikaty Mazursko Warminskie-r1993-t-n4-s511-518/Komunikaty Mazursko Warminskie-r1993-t-n4-s511-518.pdf,

106. (Paszenda 1999) Paszenda, Jerzy. 1999. Kościół Jezuitów we Lwowie. Przeglad Wschodni 4 Issue 1 (21): 101.

107. (Paszenda 2003) Paszenda, Jerzy. 2003. Kościół pw. św. Kazimierza w Wilnie. In Sztuka Kresów wschodnich. Materiały sesji naukowej - Kraków, wrzesień 2000. Edioted by Andrzej Betlej and Piotr Krasny, vol. 5, Kraków: Text, pp. 9-27, https:/www.researchgate.net/profile/Andrzej-Betlej/publication/312624761_Sztuka_kresow_wschodnich_vol_5/links/5887075 c4585150dde4ac7ff/Sztuka-kresow-wschodnich-vol-5.pdf

108. (Paszenda 2010a) Paszenda, Jerzy. 2010a. Kościół pw. św. Kazimierza w Wilnie. In Jerzy Paszenda, Budowle jezuickie w Polsce, Kraków: WAM, vol. 4, pp. 427-460.

109. (Paszenda 2010b) Paszenda, Jerzy. 2010b. Zabudowania jezuickie na Starym Mieście w Warszawie In Jerzy Paszenda, Budowle jezuickie w Polsce, Kraków: WAM, vol. 4, pp. 357-392.

110. (Paternò 2016) Paternò, Damiana Lucia. 2016. Palladio a colori, Palladio in bianco e nero: il mito del bianco nell'architettura palladiana, OPUS Incertum 2: 74-81, file:///C:/Users/Z30/AppData/Local/Temp/7911-Article\%20Text-7788-1-1-20190718.pdf

111. (Pavlík 2011) Pavlík, Milan. 2011. Proměna římsy v české architekturę po roce 1700 Kilián Ignác Dientzenhofer a Jan Blažej Santini. Umeni art 256-266, http://www.digitalniknihovna.cz/knav/view/uuid:3f8294f4-4eff-11e9-bdb5-001b21187a68?article=uuid:df43c4cc-4d54-92fb-5de 2-2097c1ed7ec7

112. (Payne 2014) Payne, Alina. 2014. The Sculptor-Architect's Drawing and Exchanges Between the Arts. In Donatello, Michelangelo, Cellini. Sculptors' Drawings from Renaissance Italy. Edited by Michael Cole, Boston: Isabella Stewart Gardner Museum and London: Paul Holberton Publishing, pp. 57-73, http://scholar.harvard.edu/files/apayne/files/sculptors architects drawings.pdf

113. (Philippot [1988] 1998) Philippot, Paul. 1998. I colori di Roma. In Paul Philippot. Saggi sul restauro e dintorni, antologia. Roma: Bonsignori 1998, pp. 73-88. First published 1888, http://www.unife.it/architettura/lm.architettura/insegnamenti/restauro/materiale-didattico/fondamenti-di-restauro-aa-2017-18 testi-facoltativi-di-approfondimenti-dispensa

114. (Philippot et al. 1986) Philippot, Paul, Laura Mora and Paolo Mora. 1986. Il Restauro degli intonaci colorati in architettura: L'esempio di Roma e la questione di metodo. Bollettino d'Arte Supplement to 35-36: 139-142, http://www.bollettinodarte.beniculturali.it/opencms/multimedia/BollettinoArteIt/documents/1372168828076 05 - P. Philipp ot - L. e P. Mora.pdf.

115. (Piana 2006) Piana, Mario. 2006. Marmorino plasters in Venice between the XVI and XVIII centuries. In Scientific Research and Safeguarding of Venice. Research Programme 2004-2006. Results 2005. Edit by Pierpaolo Campostrini. Venezia: Multigraf Spinea, vol. $\quad$ IV, pp. 71-90, http://www.iuav.it/Ateneo1/docenti/architettu/docenti-st/Mario-Pian/materiali-/Caratteri-/2005_Marmorino-plasters-in-Venic e.pdf.

116. (Piccoli 2012) Piccoli, Edoardo. 2012. Finire, rifinire, non finire. A proposito di alcune costruzioni settecentesche in muratura di mattoni. In Il cantiere storico. Organizzazione mestieri tecniche costruttive. Edited by Mauro Volpiano. Savigliano:

Fondazione CRT / L'Artistica Editrice, pp. 263-275, https://www.academia.edu/3338478/Finire_rifinire_non_finire._A_proposito_di_alcune_costruzioni_settecentesche_in_murat ura_di_mattoni

117. (Pinto 2006) Pinto, Benedetta. 2006. Lurago. In Dizionario Biografico degli Italiani, vol. 66 Istituto della Enciclopedia Italiana fondata da Giovanni Treccani S.p.A https://www.treccani.it/enciclopedia/lurago (Dizionario-Biografico)/

118. (Poplatek and Paszenda 1972) Poplatek, Jan and Jerzy Paszenda. 1972. Słownik jezuitów artystów, Kraków; WAM, pp. 83-84, 111, 253.

119. (Portoghesi 1967) Portoghesi, Paolo. 1967. Francesco Borromini. Milano: Electa, p. 53,

120. (Portoghesi 1982) Portoghesi, Paolo. 1982. L'angelo della storia. Teoria e linguaggi dell'architettura. Bari: Laterza, p. 131

121. (PPKZ 2012) Polskie Pracownie Konserwacji Zabytków S.A. 2012. Barokowy Kościół OO. Pijarów https://www.ppkz.pl/portfolio-items/barokowy-kosciol-oo-pijarow/

122. (Progetti 2014) I progetti per completare San Petronio a Bologna, Folia 2 Ottobre, https://www.foliamagazine.it/bologna-san-petronio/

123. (Progetto di intervento 2015) Il progetto di intervento sulla Cappella Cornaro in Santa Maria della Vittoria, Scheda Restauro, DBUnico2.0

http://dbunico20.beniculturali.it/DBUnicoMedia/repository/documents/26-11-2015/b6893f2b261a482a2f2eb37afffab829c0d466f 3.pdf

124. (Reichwald 1976) Reichwald, Helmut F. 1976. (Example of a finding in St. Nepomuk church in Munich). Befundblatt des Bayerische des Landesamts für Denkmalpflege. Fig.14 Form for the recording of historical stratigraphies on architectural surfaces, developed by Helmut F. Reichwald in the 1970s for the Bavarian State Office, with an example of a finding in St. Nepomuk church in Munich. From: Ursula Schädler-Saub. Please: Don't spruce up built heritage but preserve it as an authentic historic document! On the beginning of a scholarly approach to the conservation and restoration of built heritage and architectural surfaces in Germany in the 70s, CeROArt JUIN 2015, Mélanges en l'honneur de Roger Marijnissen https://doi.org/10.4000/ceroart.4744, https://journals.openedition.org/ceroart/docannexe/image/4744/img-14.jpg 
125. (Renovierung 2018)

Renovierung

des

Doms

St.

Stephan,

2018

https://regiowiki.pnp.de/wiki/Renovierung des Doms St. Stephan

126. (Repishti 2003) Repishti, Francesco. 2003. La chiesa di Sant'Alessandro in Zebedia a Milano. In La pianta centrale nella Controriforma e la chiesa di S. Alessandro in Milano (1602). Atti del convegno (Milano, 2002). Edited by Francesco Repishti and G.M. Cagni. Barnabiti Studi 19:157-176.

127. (Rinn 2010) Rinn, Barbara. 2010. Stuckateure des 17. und 18.Jahrhunderts nördlich des Mains. In Stuck des 17. und 18. Jahrhunderts. Geschichte-Technik-Erhaltung. Internationale Fachtagung des Deutschen Nationalkomitees von ICOMOS in Zusammenarbeit mit der Bayerischen Verwaltung der staatlichen Schlösser, Gärten und Seen. Würzburg, 4.-6. Dezember 2008. Edited by Jürgen Pursche. Berlin: Hendrik Bäßler, ISBN 978-3-930388-12-7 pp. 54-60, https://doczz.net/doc/5805004/der-publikation-im-pdf-format

128. (Rohatsch 2005) Rohatsch, Andreas 2005. Neogene Bau- und Dekorgesteine Niederösterreichs und des Burgenlandes. In "Junge" Kalke, Sandsteine und Konglomerate - Neogen. Edited by Bernd Schwaighofer and Walter Eppensteiner, Wien: Riegelnik, pp.

9-56, https://boku.ac.at/fileadmin/data/H03000/H87000/H87200/3Arbeitsgruppen/Veroeffentlichungen/Mitt IAG Boku_Nutz 03.p $\underline{\mathrm{df}}$

129. (Romanini 1999) Romanini, Angiola Maria. 1999. Il colore del Quirinale. In Le finiture delle architetture del Quirinale. Bollettino d'Arte. Restauri $\quad$ al $\quad$ Quirinale. Vol. http://www.bollettinodarte.beniculturali.it/opencms/multimedia/BollettinoArteIt/documents/1456327256835 06 Romanini 3. pdf.

130. (Romoli 2004/2005) Romoli, Elena. 2004/2005. Pulitura e consolidamento del fronte nord della Basilica di Sant'Andrea a Mantova. Soprintendenza Archeologia Belle Arti e Paesaggio per le province di Bergamo e Brescia Bollettino 2: 37-44, https://www.soprintendenzabrescia.beniculturali.it/getFile.php?id=181

131. (Rusińska-Kurzątkowska 1956) Rusińska-Kurzątkowska, Alicja. 1956-1957. Kościół po-jezuicki w Krasnystawie. Roczniki Humanistyczne 6/4: 111-118 file://C:/Users/Z30/AppData/Local/Temp/920-Article\%20Text-4564-1-10-20190423.pdf

132. (Santi [2004] 2021) Santi, Cesare. 2004. Comacio, Tommaso. In Historisches Lexikon der Schweiz. Version vom 14.01.2004, konsultiert am 21.09.2021. https://hls-dhs-dss.ch/de/articles/024486/2004-01-14/,

133. (Santoro 2021) Santoro, Renato. 2021. Vi lascio una citta' di marmo. Le antiche pietre di Roma. Muro Maestro 24 febbraio https://muromaestro.wordpress.com/2021/02/24/vi-lascio-una-citta-di-marmo-le-antiche-pietre-di-roma-3a/

134. (Schmeller 1957) Schmeller, Alfred. 1957. Carlone, Carlo Antonio. In Neue Deutsche Biographie 3 , p. 14 https://www.deutsche-biographie.de/sfz7908.html

135. (Schmid 2010) Schmid, Rainer. 2010. Stuckfassungen in Süddeutschland im 17. und 18.Jahrhundert - Farbe und Bedeutung. In Stuck des 17. und 18. Jahrhunderts. Geschichte-Technik-Erhaltung. Internationale Fachtagung des Deutschen Nationalkomitees von ICOMOS in Zusammenarbeit mit der Bayerischen Verwaltung der staatlichen Schlösser, Gärten und Seen. Würzburg, 4.-6. Dezember 2008. Edited by Jürgen Pursche. Berlin: Hendrik Bäßler, pp. 39-43 https://doczz.net/doc/5805004/der-publikation-im-pdf-format

136. (Segattini 2012a) Segattini, Roberto. 2012a?. Intervento di conservazione e restauro della facciata principale della Chiesa di Sant'Alessandro $\quad$ - $\quad 2010 / 2012 . \quad$ Milano nei $\quad$ cantieri dell'arte http://www2.milanoneicantieridellarte.it/cms/wp-content/files_flutter/1334041885SAlessandro tecnica.pdf

137. (Segattini 2012b) Segattini, Roberto. 2012b?. Intervento di conservazione e restauro della facciata principale della Chiesa di Sant'Alessandro. Relazione storica.

http://www.milanoneicantieridellarte.it/uploads/interventi/1334041878SAlessandro_storica.pdf

138. (Serlio 1537) Serlio, Sebastiano. 1537. Regole generali di architettura, Libro Quarto. Venetia; Francesco Marcolini.

139. (Serlio 1540) Serlio, Sebastiano. 1540. Le antiquità di Roma, Libro Terzo. Venezia: Francesco Marcolini.

140. (Smoleńska and Florczyk 2012) Smoleńska, Anna Monika Florczyk. 2012. Charakterystyka i stan zachowania kamienia użytego do budowy oraz dekoracji kościoła kolegiackiego pw. św. Anny w Krakowie. Ochrona Zabytków 65/3-4 (258-259): 27-35, https://www.nid.pl/upload/iblock/dc8/dc82d635edba2ce381843d6c8b8ef081.pdf

141. (Snaet and De Jonge 2012) Snaet, Joris and Krista De Jonge. 2012. The Architecture Of The Jesuits In The Southern Low Countries. A State Of The Art. In La arquitectura jesuítica. Edited by Maria I. Zamora, Javier I. Fernández, Jesus C. Mainar, Zagora: Colection Acta, pp. 239-276 file:///C:/Users/Z30/AppData/Local/Temp/08snaetdejonge.pdf

142. (Spiriti 2009) Spiriti, Andrea. 2009. Giovanni Angelo e Gerolamo Sala. Due scultori luganesi in Santa Maria Maggiore. Arte e Storia 44: 104-112

143. (Stankiewicz 2016) Stankiewicz, Aleksander. 2016. Wpływ fabryki i architektury kościoła jezuitów w Kaliszu na polską architekturę sakralną I poł wieku XVII, In Sztuka Polski Środkowej. Edited by Piotr Gryglewski, vol. VI, pp. 117-132, https://www.academia.edu/32298000/Wpływ_fabryki_i_architektury_kościoła_jezuitów_w_Kaliszu_na_polską_architekturę_ sakralną_I_poł_wieku_XVII_kilka_uwag_w_Sztuka_Polski_Środkowej_t_VI_red_P_Gryglewski_Łódź_2016_s_117_132

144. (Stevens 2017) Stevens, Ursula. 2017. Soldati. In: Artisti ticinesi in Europa dal XIII al XIX secolo. http://www.artistiticinesi-ineuropa.ch/ita/artistiII-sil-sol-ita.html

145. (Stępień 1995) Stępień, Piotr. 1995. Konserwacja portaligotycko-renesansowych wewnętrzach Zamku na Wawelu. Ochrona Zabytków $\quad 48 / 3-4 \quad$ (190-191): 299-310 https://bazhum.muzhp.pl/media//files/Ochrona_Zabytkow/Ochrona_Zabytkow-r1995-t48-n3_4_(190_191)/Ochrona_Zabytko w-r1995-t48-n3_4_(190_191)-s299-310/Ochrona_Zabytkow-r1995-t48-n3_4_(190_191)-s299-310.pdf 
146. (Storemyr 2001) Storemyr, Per. 2001. Jesuitenkirche Luzern - Pflegekonzept für die Nordfassade. Jahresbericht 2001. Zürich: Expert-Center für Denkmalpflege, $\quad$ pp. 29-31. https://perstoremyr.files.wordpress.com/2010/07/2001 storemyr jesuitenkirche ecd jahresbericht.pdf

147. (Storemyr 2010) Storemyr, Per. 2010. Jesuitenkirche Lucerne (CH), materials, https://per-storemyr.net/thematic-maps/jesuitenkirche-luzern/.

148. (Szewczyk and Bubicz 2020) Szewczyk, Michał and Mariusz Bubicz. 2020. Projekt rekonstrukcji barokowej polichromii elewacji frontowej krasnostawskiej świątyni. Documents of Archive of Wojewódzki Konserwator Zabytków Lublin. In Bezprecedensowe Odkrycie $\mathrm{Na}$ Elewacji Kościoła. Krasnostawska Dziedzictwo, Wydarzenia, Zabytki, 4 listopada http://www.krasnostawska.pl/bezprecedensowe-odkrycie-na-elewacji-kosciola/

149. (Tafuri 1981) Tafuri, Manfredo. 1981. Vers le Contre-Reforme. In Architeture et humanisme: de la Renaissance aux Réformes. Edited by Manfredo Tafuri and Odile Seyler, Paris: Dunod, pp. 91-126.

150. (Tanaka 1992) Tanaka, Hidemichi 1992. Leonardo da Vinci, Architect of Chambord? Artibus et Historiae 13 Issue $25: 85-102$.

151. (Ticconi 2020) Ticconi, Dimitri. 2020. Considerazioni sul primo Bernini architetto: il caso di S. Bibiana, https://www.aboutartonline.com/wp-content/uploads/2020/05/12.Ticconi.pdf

152. (Turrini 2007) Turrini, Davide. 2007. Dal Giallo Antico al Giallo di Siena. La fortuna dell'oro litico. Architettura di pietra 17 dicembre, http://www.architetturadipietra.it/wp/?p=1229

153. (Turrini 2011) Turrini, Davide. 2011. Renaissance rustication. Architettura di pietra 1 novembre, http://www.architetturadipietra.it/wp/?p=5057

154. (Unterwurzacher and Obojes 2012) Unterwurzacher, Michael and Ulrich Obojes. 2012. The Hötting Breccia: A Quaternary Building Stone: Its Formation, Quarries, Use and Material Technical Properties. Proceedings of the 10th International Congress for Applied Mineralogy (ICAM), Berlin-Heidelberg: $\quad$ Springer-Verlag, $\quad$ pp. https://link.springer.com/chapter/10.1007/978-3-642-27682-8 88.

155. (Vona 2020) Vona, Giancarlo. 2020. Palermo. Chiesa del Gesù o di Casa Professa: Camillo Camilliani - decorazione a rilievo in marmi mischi, (1597-1599), photo. Ministero dell'Interno. Fondo Edifici di culto. FEC_006718_CH03588, https://archiviodigitalefec.dlci.interno.it/fec/fotografie/detail/IT-FEC-FT0001-001318/palermo-chiesa-del-gesu-o-casa-professacamillo-camilliani-decorazione-rilievo-marmi-mischi-particolare-1597-1599.html?currentNumber $=2 \&$ startPage $=0$

156. (Waters 2016) Waters, Michael J. 2016. Reviving Antiquity with Granite: Spolia and the Development of Roman Renaissance Architecture. Architectural History 149-179, https://www.cambridge.org/core/journals/architectural-history/article/reviving-antiquity-with-granite-spolia-and-the-develop ment-of-roman-renaissance-architecture/1465A4861BEEA4ABF33A37E2DF4DBD8B

157. (Wedekind 2010) Wedekind, Wanja. 2010. Scagliola: Auf den Spuren zu möglichen Ursprüngen und Verbreitungen einer europäischen Kunsttechnik. In Stuck des 17. und 18. Jahrhunderts. Geschichte-Technik-Erhaltung. Internationale Fachtagung des Deutschen Nationalkomitees von ICOMOS in Zusammenarbeit mit der Bayerischen Verwaltung der staatlichen Schlösser, Gärten und Seen. Würzburg, 4.-6. Dezember 2008. Edited by Jürgen Pursche. Berlin: Hendrik Bäßler, pp. 213-221.

158. (Wittkower et al. [1958] 1999) Wittkower, Rudolf, Joseph Connors, Jennifer Montagu and John A. Pinto. 1999. Art and Architecture in Italy, 1600-1750: Volume 1: The Early Baroque, 1600-1625, New Haven: Yale University Press, s. 86.

159. (Wrabec 1991) Wrabec, Jan. 1991. Dientzenhoferowie czescy a Ślask, Wrocław: Zakład Narodowy im. Ossolińskich.

160. (Zander 1986) Zander, Giuseppe. 1984. La coloritura degli edifici e l'ordine architettonico. Bollettino d'Arte. Intonaci colore e coloriture nell'edilizia storica: Atti del Convegno di Studi, Roma 1984. Volume I, Supplement to 35-36: 25-30 http://www.bollettinodarte.beniculturali.it/opencms/multimedia/BollettinoArteIt/documents/1372165629070_Intonaci_colore_ e_coloritura_nelledilizia_storica.pdf 